University of New Hampshire

University of New Hampshire Scholars' Repository

Spring 1991

\title{
Gametophytic selection for early maturity in tomato (Lycopersicon esculentum Mill)
}

Mark Lawrence Crispi

University of New Hampshire, Durham

Follow this and additional works at: https://scholars.unh.edu/dissertation

\section{Recommended Citation}

Crispi, Mark Lawrence, "Gametophytic selection for early maturity in tomato (Lycopersicon esculentum Mill)" (1991). Doctoral Dissertations. 1640.

https://scholars.unh.edu/dissertation/1640

This Dissertation is brought to you for free and open access by the Student Scholarship at University of New Hampshire Scholars' Repository. It has been accepted for inclusion in Doctoral Dissertations by an authorized administrator of University of New Hampshire Scholars' Repository. For more information, please contact Scholarly.Communication@unh.edu. 


\section{INFORMATION TO USERS}

This manuscript has been reproduced from the microfilm master. UMI films the text directly from the original or copy submitted. Thus, some thesis and dissertation copies are in typewriter face, while others may be from any type of computer printer.

The quality of this reproduction is dependent upon the quality of the copy submitted. Broken or indistinct print, colored or poor quality illustrations and photographs, print bleedthrough, substandard margins, and improper alignment can adversely affect reproduction.

In the unlikely event that the author did not send UMI a complete manuscript and there are missing pages, these will be noted. Also, if unauthorized copyright material had to be removed, a note will indicate the deletion.

Oversize materials (e.g., maps, drawings, charts) are reproduced by sectioning the original, beginning at the upper left-hand corner and continuing from left to right in equal sections with small overlaps. Each original is also photographed in one exposure and is included in reduced form at the back of the book.

Photographs included in the original manuscript have been reproduced xerographically in this copy. Higher quality $6^{\prime \prime} \times 9^{\prime \prime}$ black and white photographic prints are available for any photographs or illustrations appearing in this copy for an additional charge. Contact UMI directly to order.

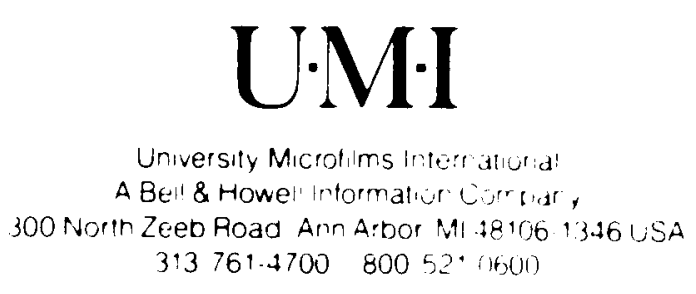


Reproduced with permission of the copyright owner. Further reproduction prohibited without permission. 
Gametophytic selection for early maturity in tomato (Lycopersicon esculentum Mill.)

Crispi, Mark Lawrence, Ph.D.

University of New Hampshire, 1991 
Reproduced with permission of the copyright owner. Further reproduction prohibited without permission. 


\title{
GAMETOPHYTIC SELECTION FOR EARLY MATURITY IN TOMATO (LYCOPERSION ESCULENTUM MILL.)
}

BY

\author{
MARK LAWRENCE CRISPI \\ B.S., Cornell University, 1983 \\ M.S., Washington State University, 1985
}

\section{DISSERTATION}

\begin{abstract}
Submitted to the University of New Hampshire in Partial Fulfillment of the Requirements of the Degree of
\end{abstract}

\author{
Doctor of Philosophy \\ in \\ Plant Science
}

May, 1991 
This dissertation has been examined and approved.

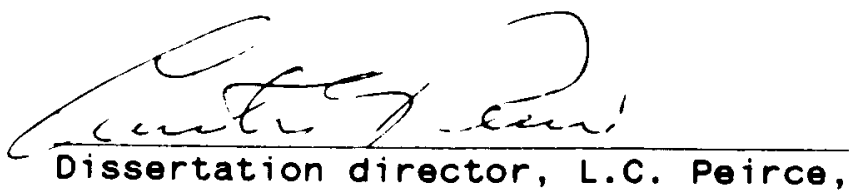

Professor of Plant Biology and

Genetics

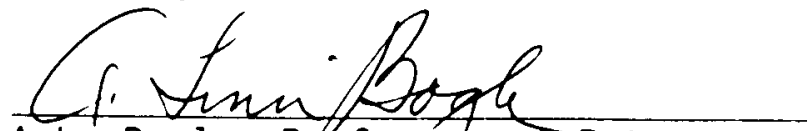

A.L. Bogle, Pubfessgr of Botany

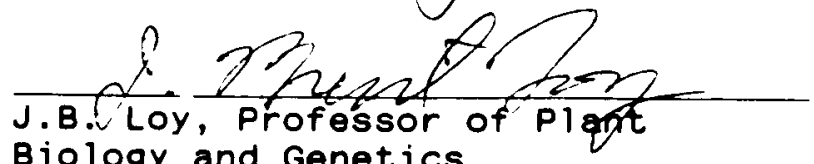

Biology and Genetics

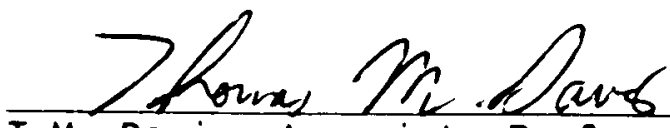

T.M. Davis, Associate Professor of Plant giology and Genetics

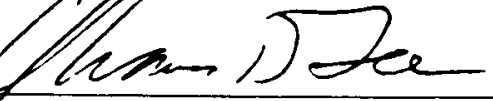

J.D. Lee, Associate Professor of

Plant Biology and Genetics

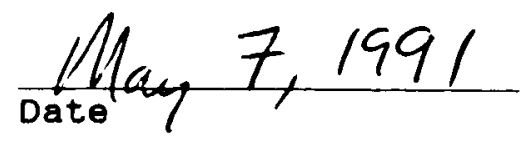




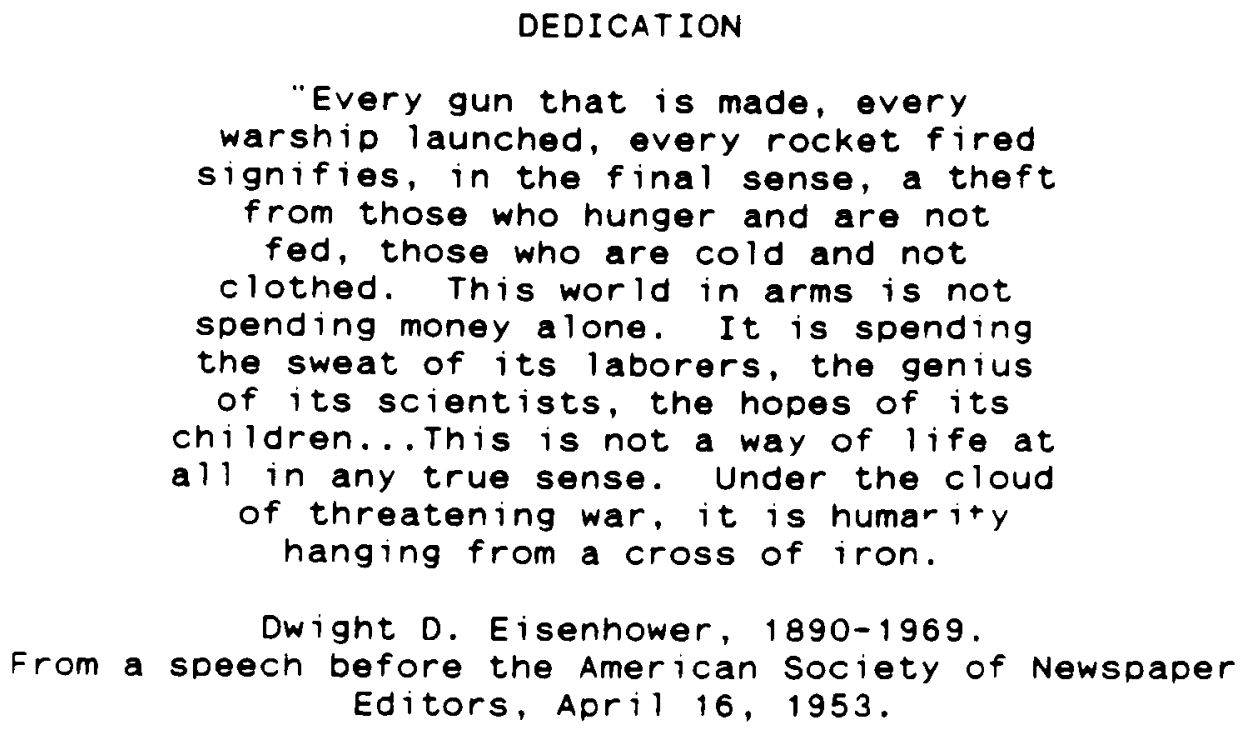




\section{ACKNOWLEDGEMENTS}

I wish to thank Dr. Lincoln C. Peirce for serving as my advisor and committee chair. I will always appreciate his friendship, encouragement, professionalism, and his Yankee sense of numor.

I also extent my appreciation and gratitude to committee members Dr. J. Brent Loy, Dr. A. Linn Bogle, Dr. Thomas Lee, and Dr. Tom Davis for their advice, assistance, and guidance. I also wish to thank the Department of plant Biology and the Graduate School of the University of New Hampshire for providing financial assistance and facilities.

I would also like to recognize Bob Parker, Bill Given, John MCLean and Suzy Wyrostek for their efforts in the greenhouse and farm on my behalf. I must thank my friends (in no order of preference) Heather Miller, Bruce Carle, Karen Rasmussen, Dave Handley, Dave Moss, Karen Gast, Leslie Matthews, Jackie Heard, Ann Greene, Mark Hutton, Bruce Chapin, and the Glovers for their assistance with my research and, most of all their friendship. I really can't express how I will miss their companionship.

Finally, I will always appreciate the support and love of my parents and family. They have waited a long time for this. 
TABLE OF CONTENTS

DEDICATION ............................ i i i

ACKNOWLEDGEMENTS.......................... iv

LIST OF TABLES......................... vi

LIST OF FIGURES......................... ix

ABSTRACT ............................. $\times 1$

SECTION PAGE

INTRODUCTION ..............................

LITERATURE REVIEW.......................... 7

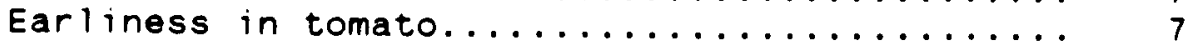

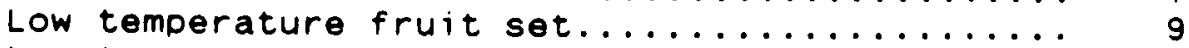

Low temperature in $v$ ivo polien function $\ldots . . . .$.

studies in tomato........................ 10

Low temperature in vitro pollen function

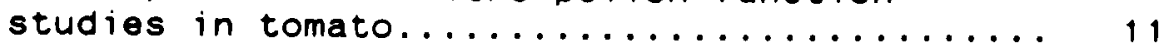

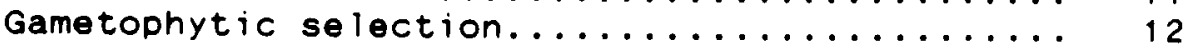

Sporophytic and gametophytic gene expression

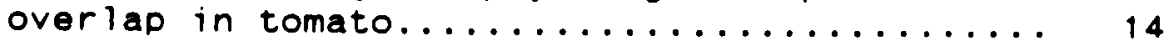

Gametophytic selection schemes for tomato..... 14

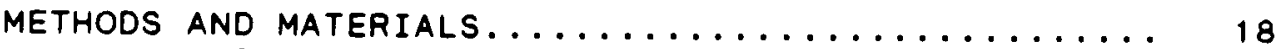

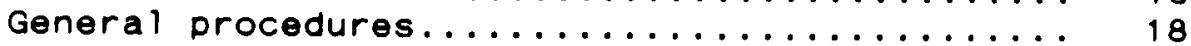

In vitro pollen germination and pollen tube growth of early and late maturing tomato

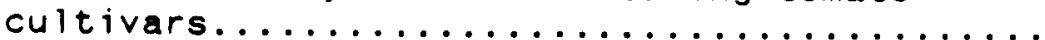

In vivo pollen germination and pollen tube growth of early and late maturing tomato

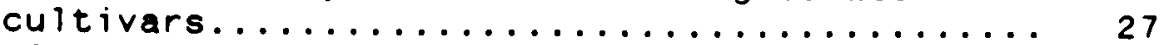

Selective fertilizations by polien mixtures of early and late maturing tomato cultivars..... 32

Selective self-fertilizations of $F 1$ hybrids of early and late maturing tomato cultivars.....

RESULTS AND DISCUSSION....................... 45

In vitro pollen germination and pollen tube growth of early and late maturing tomato

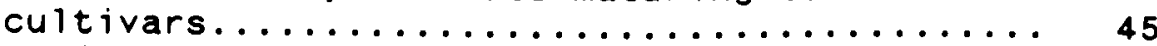

In vivo pollen germination and polien tube growth of early and late maturing tomato

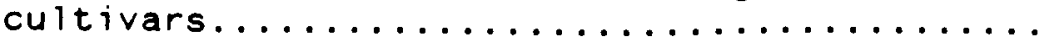


Selective fertilizations by pollen mixtures of early and late maturing tomato cultivars..... Selective self-fertilizations of $F 1$ hybrids of early and late maturing tomato cultivars..... 70

CONCLUSIONS....................... 86

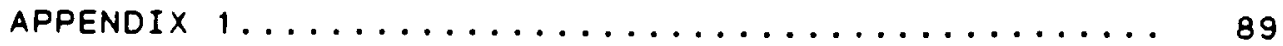

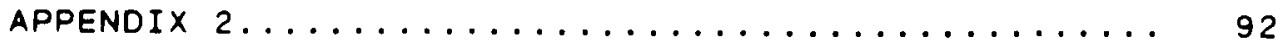

LITERATURE CITED ................... 93

$\vee i$

Reproduced with permission of the copyright owner. Further reproduction prohibited without permission. 


\section{LIST OF TABLES}

TABLE

PAGE

1 Maturity class, uniformity of unripe fruit color, flesh color, and seed source of six tomato cultivars used for gametophytic

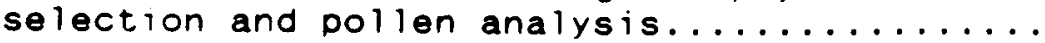

2 Crosses made in each growth chamber for Experiments 3.1 and $3.2 \ldots \ldots \ldots . \ldots \ldots$

3 Procedural differences between Experiments

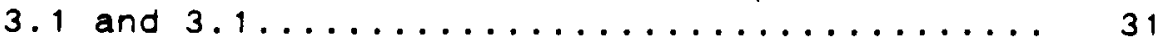

4 Crosses made for Experiments 4.1 and $4.2 \ldots 35$

5 Entries planted in Field Experiments 4.1

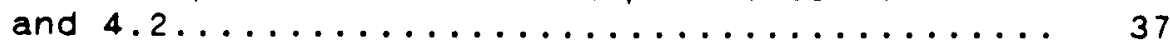

6 Procedural differences between Experiments

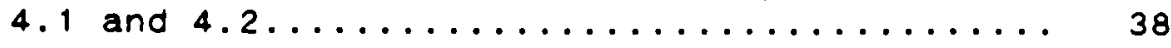

7 Fi hybrids self-pollinated under selective conditions in Experiments $5.1,5.2$, and $5.3 \ldots 40$

8 Entries planted in Field Experiments 5.1 ,

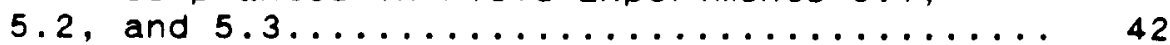

9 Procedural differences among Experiments

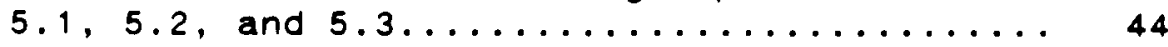

10 Variances from analysis of percentages of pollen germination, and mean pollen tube lengths for six tomato cultivars............

11 Contingency Chi-square analyses of segregation of genetic markers in Experiment 4.1 , planted in summer, 1988..............

12 Percent fruit set and mean seeds per fruit after pollination treatment in

Experiment $4.2 \ldots \ldots \ldots \ldots \ldots \ldots . \ldots \ldots \ldots . . . \ldots \ldots$

13 Contingency Chi-square analyses of segregation of genetic markers in Experiment 4.2 , planted in summer, 1990............... 
14 Percent fruit set and mean seeds per fruit

after self-pollination at normal (25 C day /

$20 \mathrm{C}$ night) or low ( $15 \mathrm{C}$ day / $10 \mathrm{C} \mathrm{night)}$

temperature in Experiment $5.1 \ldots \ldots \ldots \ldots \ldots$

15 Summary of days from seeding to first

flower from Experiments $5.1,5.2$, and $5.3 \ldots \ldots$

16 Contingency Chi-square analyses of

Experiments $5.1,5.2$, and $5.3 \ldots \ldots \ldots \ldots 74$

17 Summary of days from seeding to first ripe

from Experiments $5.1,5.2$, and $5.3 \ldots \ldots \ldots 75$

18 Contingency Chi-square analyses of

Experiments $5.1,5.2$, and $5.3 \ldots \ldots \ldots 76$

19 Percent fruit set and mean seeds per fruit

after self-pollination at normal ( $25 \mathrm{C}$ day/

$20 \mathrm{C}$ night) or low ( $15 \mathrm{C}$ day / $10 \mathrm{C}$ night)

temperature in Experiment $5.2 \ldots \ldots \ldots \ldots 78$

20 Percent fruit set and mean seeds per fruit after self-pollination at normal (25 $\mathrm{C}$ day / $20 \mathrm{C}$ night) or low (15 C day / $10 \mathrm{C}$ night)

temperature in Experiment $5.3 \ldots \ldots \ldots \ldots \ldots$ 


\section{LIST OF FIGURES}

FIGURES

PAGE

1 Tomato earliness components, lifecycle phases associated with the components, and the environment encountered by fieldgrown tomato plants in this study........... 4

2 Vibratory collector for tomato pollen, modified from Rick $(1980) \ldots \ldots \ldots \ldots \ldots \ldots . \ldots . \ldots 21$

3 Temperature gradient device, modified from Chatterton and Kadish (1969) and Hensley

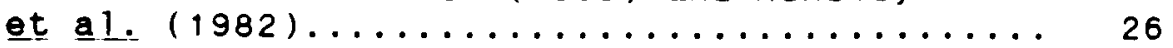

4 Staining procedure for Experiment 3, modified from Martin (1959)............. 30

5 Temperature by cultivar interactions for percent pollen germination and mean pollen tube length....................... 46

6 Percent pollen germination at three temperatures and four incubation.times

for six tomato cultivars................

7 Mean pollen tube lengths at three temperatures and four incubation times for six tomato

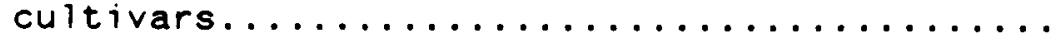

8 Relationship between temperature and percent pollen germination, after three hours of incubation, for four tomato cultivars........

9 Relationship between temperature and percent pollen germination, after six hours of incubation, for four tomato cultivars........

10 Relationship between temperature and mean pollen tube length, after three hours of incubation, for four tomato cultivars........

11 Relationship between temperature and mean pollen tube length, after six hours of incubation, for four tomato cultivars........ 
12 Effect of temperature regime and duration on mean pollen tube length (relative to style length) and pollen tube number for 'Bellstar' pistils pollinated in 1988 by one of four

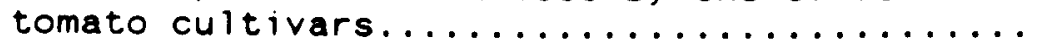

13 Effect of temperature regime and duration on mean pollen tube length (relative to style length) and pollen tube number for

'Earlirouge' pistils pollinated in 1988 by one of four tomato cultivars.............

14 Effect of temperature regime and duration on mean pollen tube length (relative to style length) and pollen tube number for 'Bellstar' pistils dollinated in 1990 by one of four

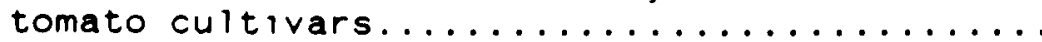

15 Effect of temperature regime and duration on mean pollen tube length (relative to style length) and pollen tube number for

'Earlirouge' pistils pollinated in 1990 by

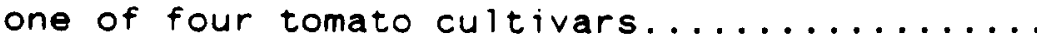




\begin{abstract}
GAMETOPHYTIC SELECTION FOR EARLY MATURITY IN TOMATO (LYCOPERSICON ESCULENTUM MILL.)

by

Mark Crispi

University of New Hampshire, May, 1991

The feasibility of applying low temperature as a screen for selecting early gametes during pollination of tomato flowers was investigated. Pollen germination and tube growth on solidified agar were evaluated at 8,15 , or $25 \mathrm{C}$ after $6,12,18$, or 24 hours of incubation for two early-, two intermediate-, and two late-maturing tomato cultivars. Pollen from early cultivars showed superior germination and tube growth at $25 \mathrm{C}$, whereas pollen germination and tube growth of late cultivars were greatest at $15 \mathrm{C}$. Pollen germination and tube growth of the two early and two late cultivars were evaluated at three (three hour incubation) or five (six hour incubation) temperatures between 10 and $16 \mathrm{C}$. The relationships between temperature and in vitro pollen germination or tube growth fit a second degree polynomial for all cultivars. The relationship between optimal temperatures for pollen germination and tube growth and the maturity of the cultivar was further investigated by placing pollen from early and late cultivars on intermediatematuring females and exposing plants to $25 \mathrm{C}$ day/ $20 \mathrm{C}$ night
\end{abstract} $x i$ 
and $15 \mathrm{C}$ day/ $10 \mathrm{C}$ night temperatures. Low temperature reduced pollen germination and tube growth rate for all cultivars, regardless of maturity class.

To simulate a population of segregating gametes, pollen mixtures from early and late cultivars were applied to intermediate females under normal and low temperatures. After 48 or 72 hours, styles of pollinated pistils were cut. Low temperatures severely reduced percent fruit set and number of seeds per fruit. However, pollen of earlymaturing cultivars had no competitive advantage at either temperature.

Hybrids from crosses of similar and different maturity classes were artifically self-pollinated under low and normal temperatures, and after 72 or 96 hours, styles were cut. Low temperature self-pollinations reduced percent fruit set and number of seeds per fruit. Field comparisons of $F_{2}$ populations derived from low and normal temperature self-pollinations revealed no siznificant shifts in earliness.

Under low or normal pollination temperatures, in vitro polien germination and tube growth did not correspond to in vivo germination and tube growth. Furthermore, the gametophytic selection scheme used did not cause significant shifts in maturity. 
INTRODUCTION

The life cycle of a plant alternates between sporophytic (diploid) and gametophytic (haploid) phases. Because the sporophytic phase is more prominent than the gametophytic phase, both in duration and in economic importance, plant breeders traditionally have favored sporophytic selection schemes. However, when the number of loci controlling a desirable character is high (e.g. a quantitatively inherited character), large plant populations are needed to increase the opportunity to obtain superior zygotes. Selection progress during the sporophytic phase, therefore, often is limited by the number of plants that can be screened at one time. If selection for a quantitative trait could be effected in the male gametophytic phase, the number of plants required for selection would be less than that required for a sporophytic selection scheme (Zamir, 1983). For example, the smallest $F_{2}$ population showing all genotypes from an $F_{1}$ heterozygous for ten loci would be $4^{10}$ $=1,048,576$. Growing this many tomato plants in the field would be virtually impossible. However, it would be relatively simple to screen and select among the 210 (1024) different haploid gametes and then evaluate a smaller, preselected F2 population of sporophytes. A major question in the development of a gametophytic selection scheme is whether the desired trait is expressed in the haploid stage. 
Another concern is the appropriateness of the selection pressure employed in terms of selecting the desired genotype(s).

The development of early-maturing tomato (Lycopersicon esculentum Mill.) cultivars has been and continues to be a main objective of both processing and fresh market tomato breeding programs. Tomato earliness has been measured several ways, including length of time from seeding to fruit ripening (expressed in days and in growing degree-days), and number and/or weight of ripe fruit by a particular harvest date (Bernier and Ferguson, 1962; George and Peirce, 1969; Gibrel et al., 1982). To facilitate genetic studies of the inheritance of earliness, investigators have divided the time from seeding to date of first ripe fruit into components (Fogle and Currence, 1962), including number of days to first flower (anthesis), first flower to first fruit set, and first fruit set to first ripe fruit (Bernier and Ferguson, 1962; Fogle and Currence, 1950; Gibrel et al.., 1982; Honma et al., 1963; Kerr, 1955; Powers and Lyon, 1941). Inheritance studies of earliness and its components in field-grown tomatoes have indicated that earliness (and its components) are quantitatively inherited and greatly influenced by environmental conditions (Bernier and Ferguson, 1962; Cuarto and Cubero, 1982; Fogle and Currence, 1950; Gibrel et al., 1982; Kerr, 1955; Powers and Lyon, 1941). If a gametophytic selection scheme were to be 


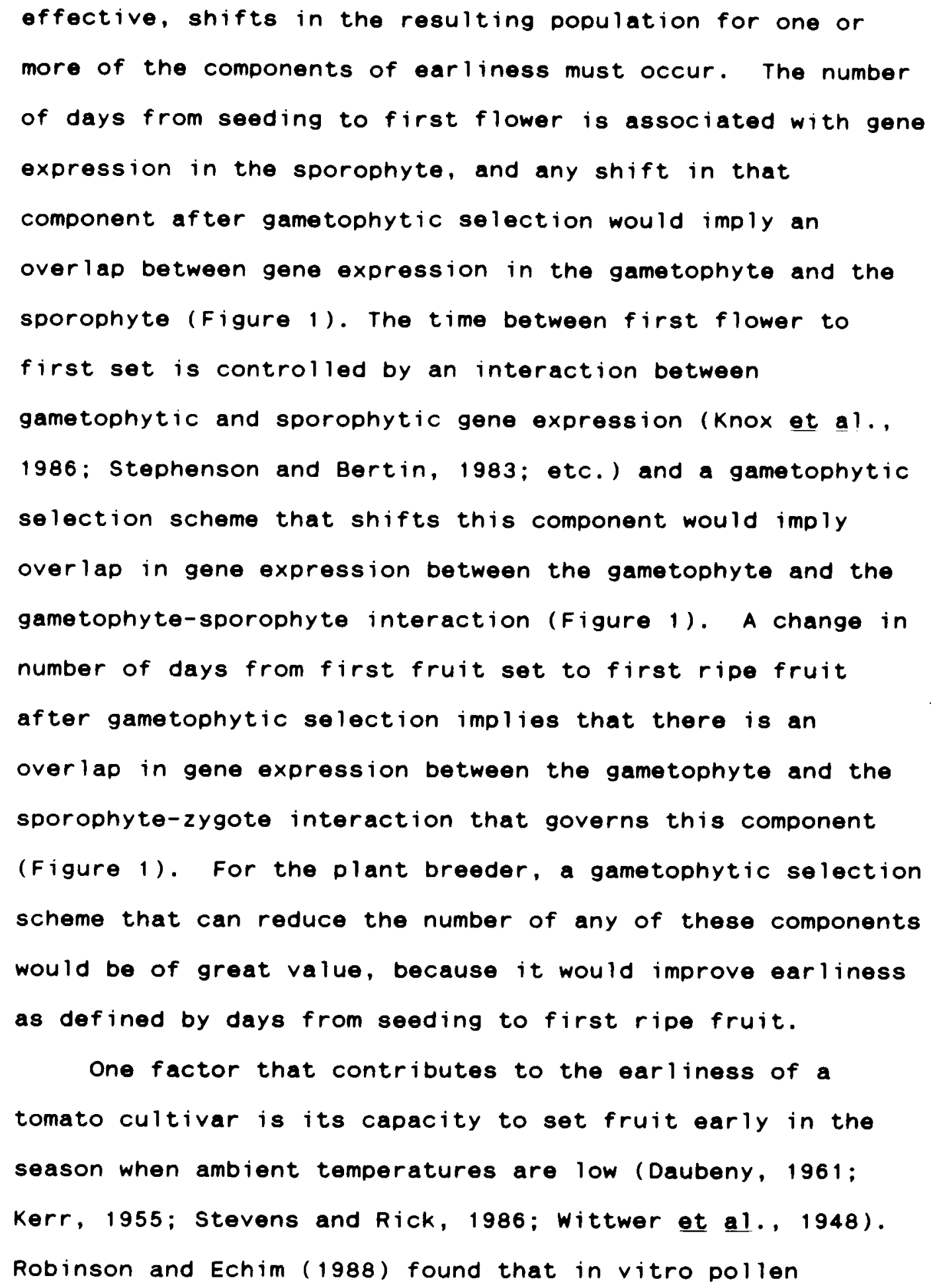



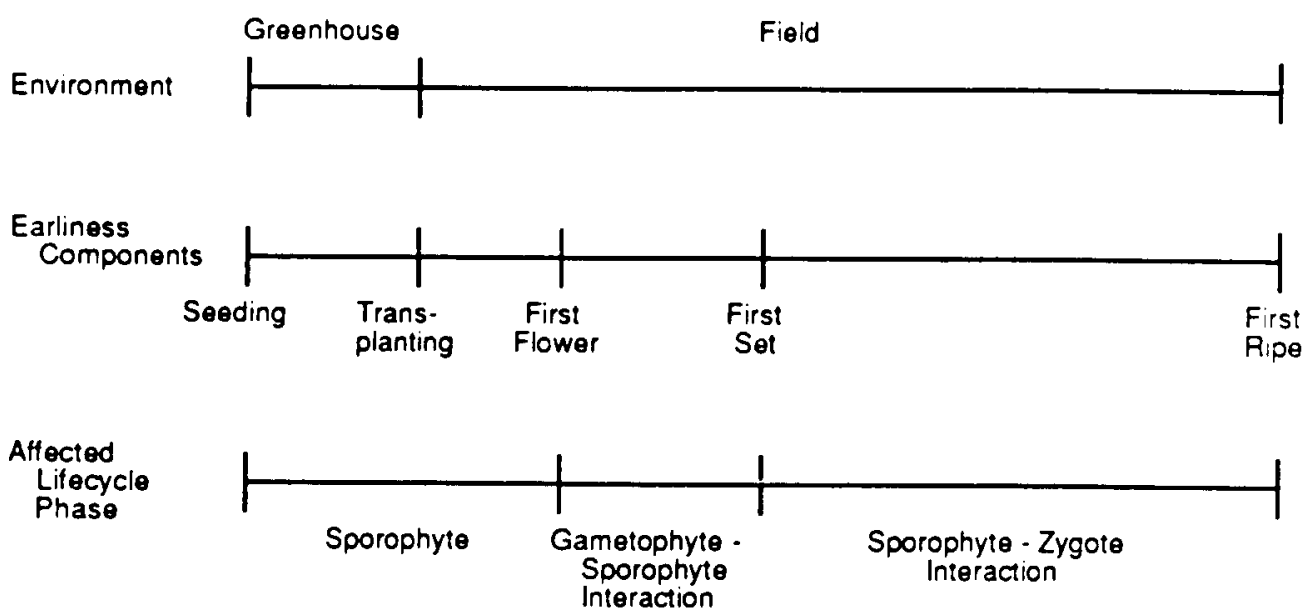

Figure 1. Tomato earliness components, lifecycle phases associated with the components, and the environment encountered by field-grown tomato plants in this study. 


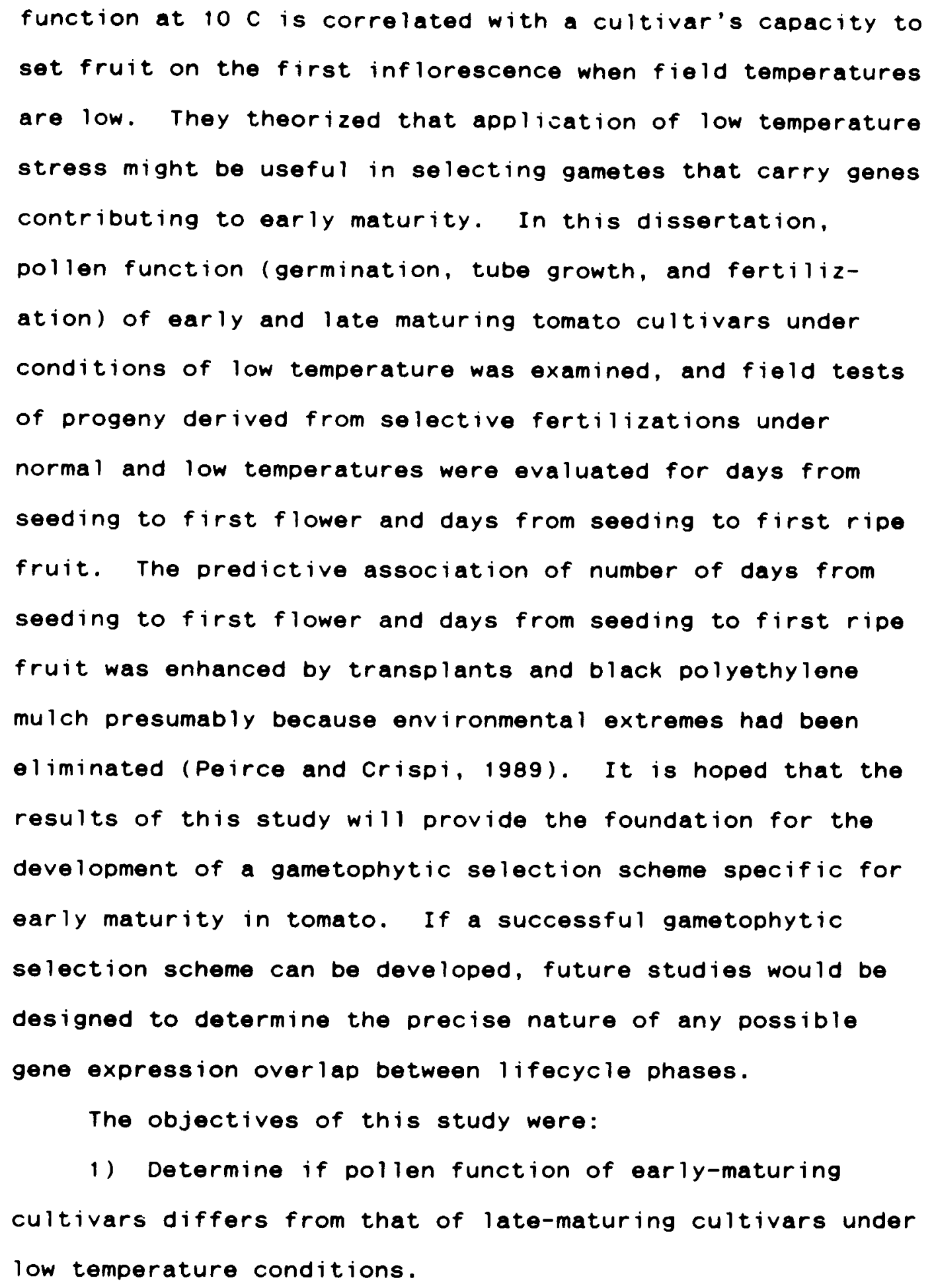


2) Determine if in vitro Dollen behavior (germination, tube growth) corresponds with in vivo pollen behavior (fertilization) under low-temperature conditions.

3) Determine if gametophytic selection under lowtemperature stress can be used to select early-maturing tomato plants. 


\section{LITERATURE REVIEW}

\section{Earliness in tomato}

Early production of tomato (Lycopersicon esculentum Mill.) may be improved through cultural systems and genetic enhancement. Genetic improvement of earliness has been a major objective of both fresh market and processing tomato breeders (Gould, 1974; Kerr, 1955). Earliness in tomatoes is important because "early fruit brings the highest price on the fresh market" (Daubeny, 1961), and because earliness "advances, extends and makes more manageable the tomato harvest" for the processing tomato grower (Gould, 1974). Hence, an understanding of the components and inheritance of earliness is of great importance to the plant breeder.

Tomato earliness has been measured several ways, including length of time from seeding to fruit ripening (expressed in days and in growing degree-days), and number and/or weight of ripe fruit by a particular harvest date (Bernier and Ferguson, 1962; George and Peirce, 1969; Gibrel et al., 1982). To facilitate genetic studies of the inheritance of earliness, investigators have divided the time from seeding to date of first fruit ripe into components (Fogle and Currence, 1962), including number of days to first flower (anthesis), first flower to first fruit set, and first fruit set to first ripe fruit (Bernier and Ferguson, 1962; Fogle and Currence, 1950; Gibrel et al.., 
1982; Honma et a 1., 1963; Kerr, 1955; Powers and Lyon, 1941). Inheritance studies of earliness and its components in field-grown tomatoes have indicated that earliness (and its components) are quantitatively inherited and greatly influenced by environmental conditions (Bernier and Ferguson, 1962; Cuarto and Cubero, 1982; Fogle and Currence, 1950; Gibrel et al., 1982; Kerr, 1955; Powers and Lyon, 1941). Under controlled greenhouse conditions, Honma et al. (1963) studied days from seeding to first flower and concluded that this component of earliness was controlled by a single gene that "interacted so greatly with the environment that field studies would indicate a quantitative pattern of inheritance." Regardless of the number of genes, it is clear that earliness and its components are highly variable in response to environment (Cuarto and cubero, $1982)$.

Peirce and Crispi (1989) were able to enhance the predictive association between days from seeding to first flower and days from seeding to first ripe fruit in the field by using transplants, black polyethylene mulch, and clear polyethylene row covers. These cultural treatments tended to remove extremes of environment, enabling a breeder to improve earliness by selecting genotypes that flower $\operatorname{ear} 1 y$. 


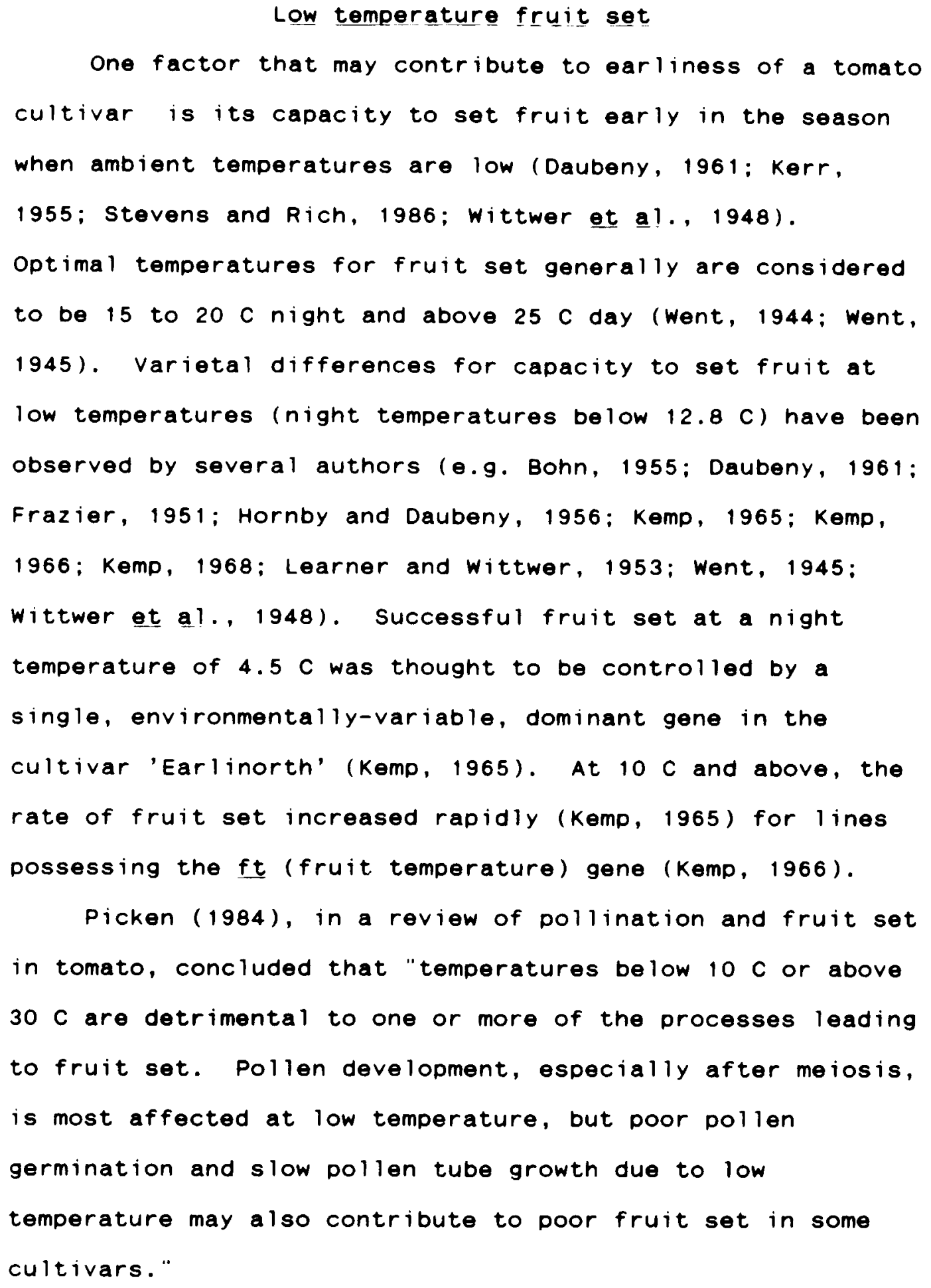




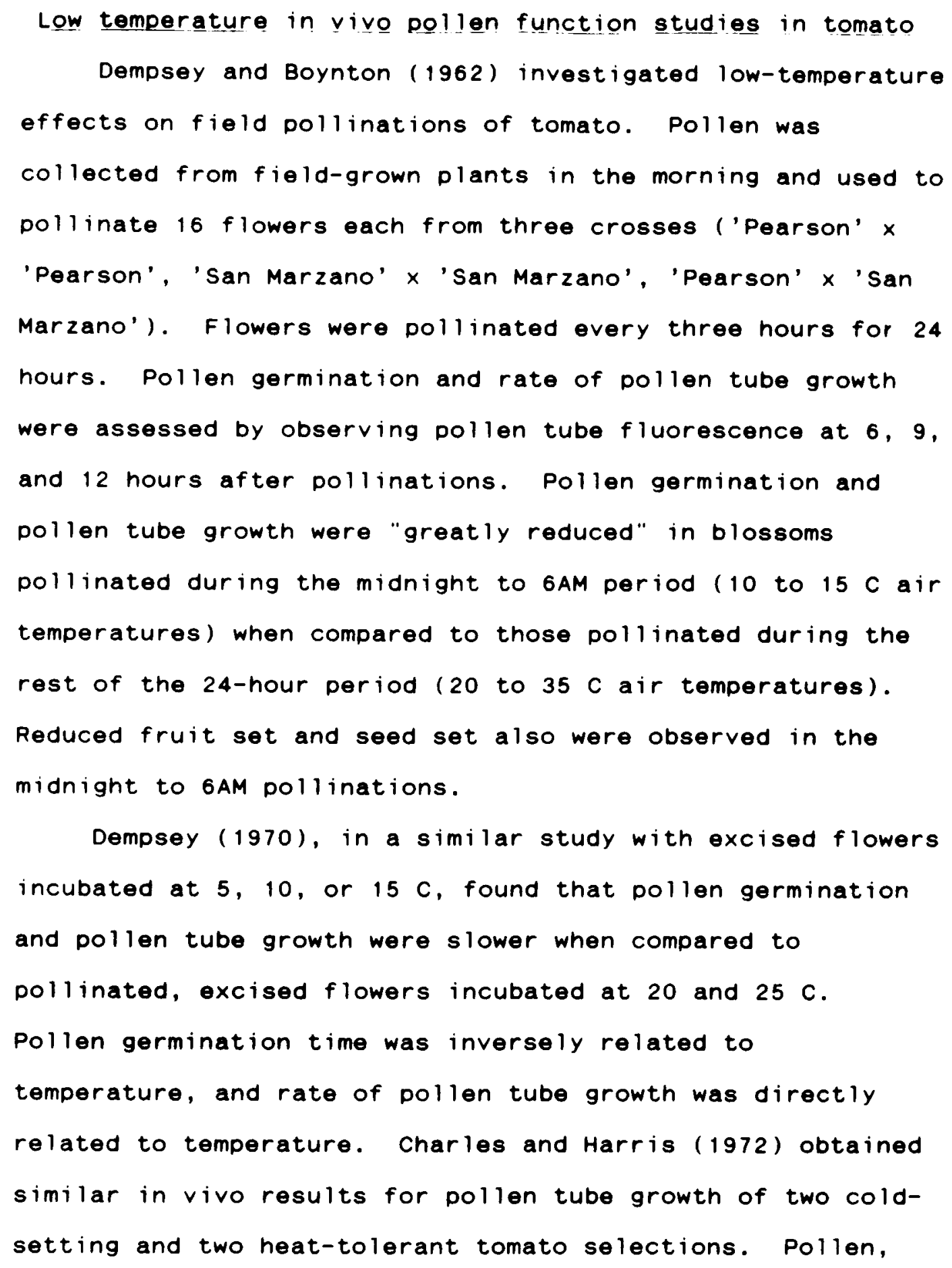


produced at 18.3 or $26.7 \mathrm{C}$, was applied to the stigmas of excised male-sterile flowers and incubated at 10, 18.3, or $26.7 \mathrm{C}$. Pollen tubes penetrated the ovary in 24 hours in the $18.3 \mathrm{C}$ and $26.7 \mathrm{C}$ incubated flowers, but tubes required 84 hours to reach the ovary in flowers incubated at $10 \mathrm{C}$.

\section{Low temperature in vitrro pollen function studies in tomato In vitro evidence for low temperature inhibition of} pollen function has been obtained by several investigators. Charles and Harris (1972) collected pollen from two coldsetting and two heat-tolerant selections. Collected pollen was incubated separately on artificial medium at $10,18.3$ or $26.7 \mathrm{C}$. Pollen germination was greatest for the $18.3 \mathrm{C}$ incubation and lowest for the $10 \mathrm{C}$ incubation. Zamir et al. (1981), obtained pollen from cultivated tomato and $L$. hirsutum Humb. and Bonpl. (a high-altitude Peruvian ecotype) and incubated the pollen separately on an artificial medium at $5 \mathrm{C}$ (100 hours duration) or $15 \mathrm{C}$ ( 8 hours duration). At $5 \mathrm{C}$, pollen germination was inhibited to a greater extent in the cultivated tomato than in the cold-tolerant Peruvian ecotype.

Maisonneuve and Den Nijs (1984) reviewed pertinent literature and found that tomato cultivar differences for in vitro pollen germination and tube growth had been observed at both low and normal temperatures. In their own study, Maisonneuve and Den Nijs compared in vitro pollen 


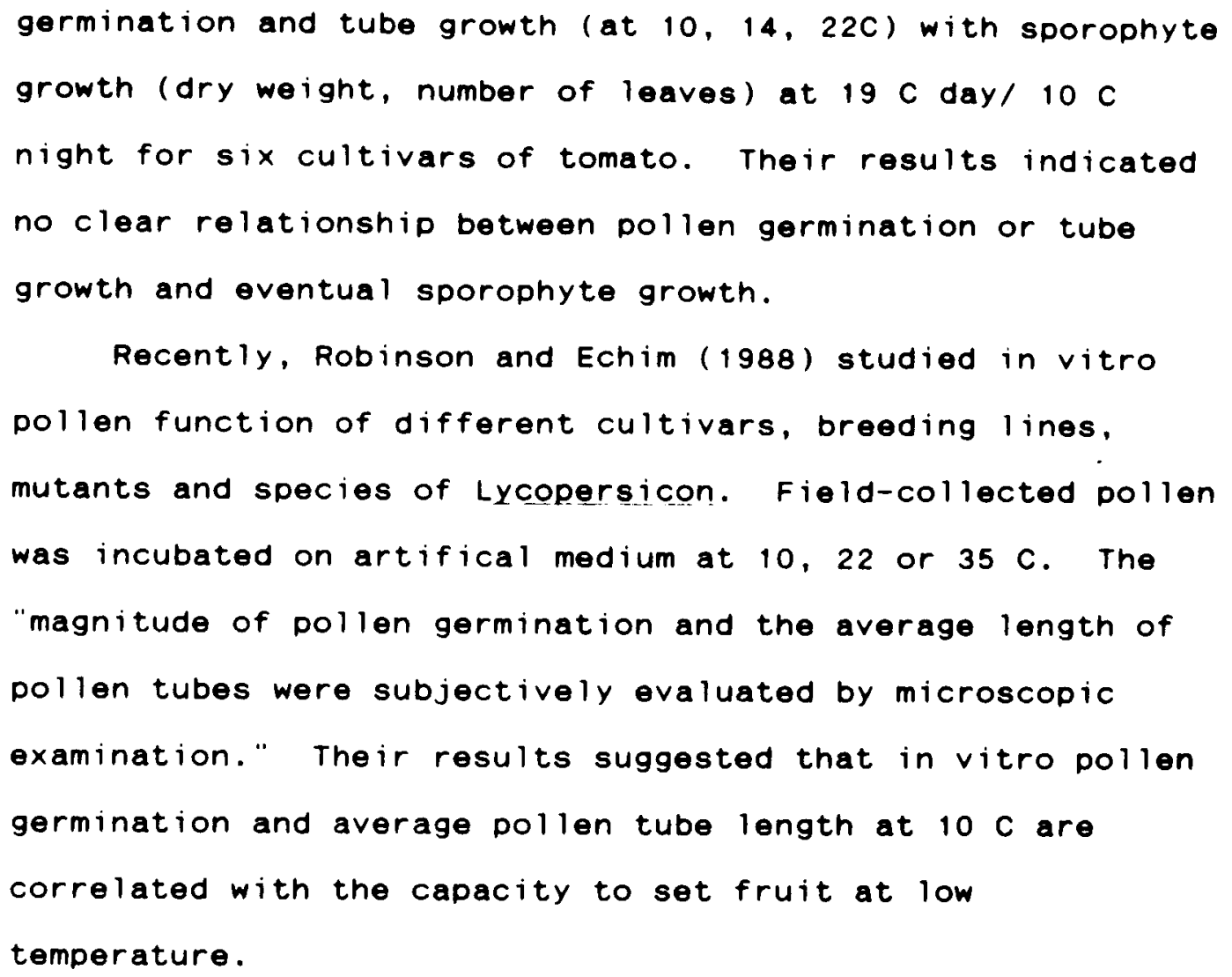

Gametophrtic selection

Traditionally, plant breeders have favored sporophytic (diploid) selection schemes. When the number of genes controlling a desirable character is high (e.g. a quantitatively inherited character), selection progress during the sporophytic phase is often limited by the large number of plants that must be screened to obtain a desired genotype.

Gametophytic selection implies the ability to recognize desirable genotypes in the haploid or gametophytic phase of 
a plant's life cycle. The theory and evidence favoring gametophytic selection over sporophytic selection has been eloquently reviewed by Hutton (1988) and can be summarized as follows:

a) male gametophytes (which develop into pollen) greatly outnumber female gametophytes during a typical pollination event;

b) pollen grains successfully compete prior to fertilization of female gametophytes by germinating rapidly and/or having rapid pollen tube growth rates;

c) competitive ability due to transcription of loci in both the haploid and diploid phases of the life cycle would result in the overlap of gametophyte and sporophyte gene expression:

d) a high degree of overlap in gene expression between the gametophytic and sporophytic phases indicates "that selection in one phase should have a high probability of influence in the remaining phase;" and e) if the correct selective agent is found and the pollenselected genes are expressed in the sporophyte, then the breeder could drastically reduce the number of field plants required to screen for a desired genotype in progenies produced by selected pollen. 
Sporophytic and gametophytic gene expression overlap in tomato

\begin{abstract}
Evidence for overlap of sporophytic and gametophytic gene expression in tomato ( $L$. esculentum) was obtained by Tanksley et al (1981). In that study, isozyme profiles of sporophytic tissue (roots, leaves, and seeds) were compared with those of the male gametophyte (pollen) for nine enzyme systems. Sixty percent of the 30 isozymes present in the sporophyte were found in the gametophyte, and 18 of the 19 gametophytic isozymes also were found in the sporophytic tissue. According to the authors, these results "support the concept that selection for genes expressed in the gametophytic stage could have a marked effect on the sporophytic generation, since many of these genes are expressed in both generations."
\end{abstract}

Gametophytic selection schemes for tomato Richardson and Currence (1953) developed an in vivo gametophytic selection scheme to alter the segregation of several traits in the $F_{2}$ of a cross between an early- and a late-maturing cultivar. Selection was accomplished by cutting the $F_{1}$ style at different intervals after natural pollination. Stylar cutting 24 hours after pollination altered the segregation of several characters (fruit set, seed set, weight per seed, fruit shape) but had no effect on two components of earliness (days from seeding to first 
flower and days from seeding to first ripe fruit). Seeds also were selected, based on location in the $F_{1}$ fruit. Early yield (amount of fruit harvested prior to september 8 th) was slightly but significantly greater $(14.3$ to 12.3 pounds) on plants grown from stem-half seeds of naturally set fruit than it was on those grown from comparable blossom-end halves.

Zamir et al. (1981) devised a gametophytic selection scheme using low temperature as the selective agent. Mixtures were prepared from pollen harvested from $\underline{L}$. esculentum and L. hirsutum. Greenhouse grown plants of L. esculentum were transferred to growth chambers and pollinated with the mixtures. Fertilizations occurring during a 12 C light/ 6 C dark regime resulted in the doubling of the frequency of $L$. hirsutum gametes contributing to hybrid formation as compared to fertilizations with the same mixtures at $24 \mathrm{C}$ light/ $19 \mathrm{C}$ dark. These results suggested that selection at the pollen level occurs in response to low day/night temperature treatments.

In a continuation of their previous study, zamir et al. (1982) harvested polien from a greenhouse-grown interspecific $F_{1}$ hybrid between L. esculentum and L. hirsutum and applied this pollen to greenhouse-grown plants of $L$. esculentum. The flowers were pollinated within two temperature regimes ( $24 \mathrm{C}$ light/19 C dark and $12 \mathrm{C} 1$ ight/ 6 
C dark). BC, plant tissue then was analyzed electrophoretically for loci that mark six of the 12 tomato chromosomes. Isozyme analysis indicated that two chromosomal regions of L. hirsutum, linked to the enzymatic genes Pgi-1 and Adh-2, are highly favored in crosses at low temperature. The authors concluded "that the low temperature tolerance of $L$. hirsutum pollen grains is determined by genes expressed in the pollen genome." Zamir and Vallejos (1983) expanded on the work of Zamir et al. ( 1982 ) by electrophoretically comparing BC, plants ((L. esculentum $\times$ L. hirsutum $) \times$ L. esculentum) obtained from pollinations performed under two different temperature regimes (24 C light/19 C dark and $12 \mathrm{C}$ light/ $6 \mathrm{C}$ dark) with those pollinated using pollen developed under the same two temperature regimes. They found that "haploid selection for low temperature tolerance is stronger during pollen function than during pollen formation."

In order to develop salt-tolerant tomato plants, sacher et al. (1983) developed a gametophytic selection scheme that employed $\mathrm{NaCl}$ as the selective agent. Fi plants from the cross L. esculentum CV. 'New Yorker' (salt sensitive) $\times$ L. pennellii (Corr.) D'Arcy (salt tolerant) were grown under control and salt stress conditions. It was found that $F_{2}$ plants derived from salt-stressed $F_{1}$ plants were more vigorous when grown under both saline and control conditions than the $F_{2}$ plants from control $F_{1}$ plants. 


\begin{abstract}
Maisonneuve et al. (1986) developed a method to select for growth capacity at low temperature. $F_{2}$ and $B C_{1}$ progenies were produced by crossing tomato cultivars differing in low temperature adaptation. Flowers were pollinated under two temperature regimes $(22 \mathrm{C} 1 \mathrm{ight} / 15 \mathrm{C}$ dark and 15 C 1 ight/8 C dark) with pollen formed under both regimes. Progenies were compared for vegetative growth (leaf and stem dry weights) at a low temperature regime (19 c light/ $10 \mathrm{c}$ dark). From the results obtained, the authors concluded that "low temperature treatment of a heterozygous plant during pollen formation or pollen germination did not appear to aid sporophytic selection."

Using low temperature as a selective agent, zamir and Gadish (1987) developed a system to select for tomatoes adapted to low temperature. Pollen harvested from an $F_{1}$ hybrid between L. esculentum and L. hirsutum, was applied to stigmas of male-sterile L. esculentum plants in growth chambers set at $12 \mathrm{C} 1$ ight/ $7 \mathrm{C}$ dark, and $24 \mathrm{Clight/18 \textrm {C }}$ dark. $B C_{1}$ seeds from both temperature treatments were germinated, and root elongation rates were measured at $9 \mathrm{C}$ or $24 \mathrm{C}$. The results indicated that root elongation of seedlings from the low-temperature crosses was less inhibited by the cold than root elongation for progenies of the normal-temperature crosses.
\end{abstract}


Five experiments were developed based upon the previously stated objectives. Several procedures and materials used repeatedly within these experiments are described under "General procedures". All experiments were conducted in facilities located at either the University of New Hampshire or the US Forest Service Northeast Forest Experiment station (NFES), Durham, NH.

\section{General Procedures}

\section{Plant Materia!}

To reveal evidence of gametophytic selection, six tomato (L. esculentum) cultivars were required that differed in maturity type (early, intermediate, or late), specific single-gene varietal characteristics (i.e. mature fruit color and uniform unripe color genes), and pollen germinability and pollen tube growth rates at low temperature (15 to $8 \mathrm{C}$ ). The six cultivars (Table 1) were chosen from among 21 cultivars evaluated for these differences at Woodman Farm, Durham, NH, during the summer of 1987. Pollen germination and tube growth were measured for each of the 21 cultivars at three temperatures $(8,15$, or $28 \mathrm{C}$ ) after 24 hours of incubation on an artifical medium. The results of this preliminary study suggested that within the chosen cultivars, low temperature (15 to 8 
Table 1. Maturity class, uniformity of unripe fruit color, flesh color, and seed source of six tomato cultivars used for gametophytic selection and pollen analysis.'

\begin{tabular}{|c|c|c|c|c|c|}
\hline Cultivar & $\begin{array}{c}\text { Maturity } \\
\text { class }\end{array}$ & $\begin{array}{l}\text { First } \\
\text { flower }\end{array}$ & $\begin{array}{r}\text { First } \\
\text { ripe }\end{array}$ & Genotype 3 & $\begin{array}{l}\text { Seed } \\
\text { source }\end{array}$ \\
\hline Gemstate & $E$ & 46 & 87 & $U U, O^{c} O g^{c}$ & $J$ \\
\hline Rocket & $E$ & 46 & 85 & uu, Ogc Oge & $\mathrm{s}$ \\
\hline Earlirouge & I & 53 & 95 & uu, $o^{c} \circ g^{c}$ & $"$ \\
\hline Bellstar & I & 52 & 96 & $u u, o g^{c} \circ g^{c}$ & $"$ \\
\hline Crimsonvee & L & 50 & 109 & ugug, ogcoge & $"$ \\
\hline Harvestree & L & 57 & 108 & $u u, o g^{c} \circ g^{c}$ & - \\
\hline
\end{tabular}

1 Pedigree of each cultivar is in Appendix 1.

2 Maturity class based on catalog description: $E=$ early; $I$

= intermediate; $L=$ late.

3 Gene symbols: $U=$ green shoulder; $u=$ uniform ripening; ug

= uniform grey-green; $R=$ red flesh; Ogc = red flesh: oge = crimson flesh.

- J = Johnny's Selected Seeds, Albion, Maine; $s$ = Stokes

Seeds Inc., Buffalo, New York. 
C) could be used to inhibit pollen germination and pollen tube growth rates selectively (data not shown).

For all subsequent winter growth chamber and greenhouse tests, seeds were sown in september or October in seedling flats filled with a peat-vermiculite mix (Redi-earth, W.R. Grace and Co., Cambridge, MA) and placed in the UNH greenhouse. Greenhouse temperatures were maintained as indicated for each specific experiment. When seedlings reached the two-leaf stage, they were transplanted to $7.5 \mathrm{~cm}$ Jiffy strip pots (Jiffy Products, Shippegan, Canada). Rediearth, amended with 14N-6.1P-11.6K controlled-release fertilizer (Osmocote, Grace Sierra, Milpitas, CA) at $0.7 \mathrm{~kg}$ $\mathrm{N} /$ ha, was used as the growing medium. When seedlings were approximately $12 \mathrm{~cm}$ in height, each was transplanted into a larger pot containing a growing medium of Redi-earth (amended with Osmocote at the previous rate) to which 1.6 $\mathrm{kg} / \mathrm{m}^{3}$ of dolimitic lime was added. Plants were staked, tied and pruned when necessary.

\section{Pollen Collection and Poll linations}

Pollen collected from flowers of each cultivar one day after anthesis by means of a vibratory collector (Figure 2, design adapted from Rick, 1980) was placed in gelatin capsules (No. O, Eli Lilly and Co., Indianapolis, IN). Pollen was collected daily (9:30AM to 10:30AM) to provide a fresh supply for each day of pollinations. 


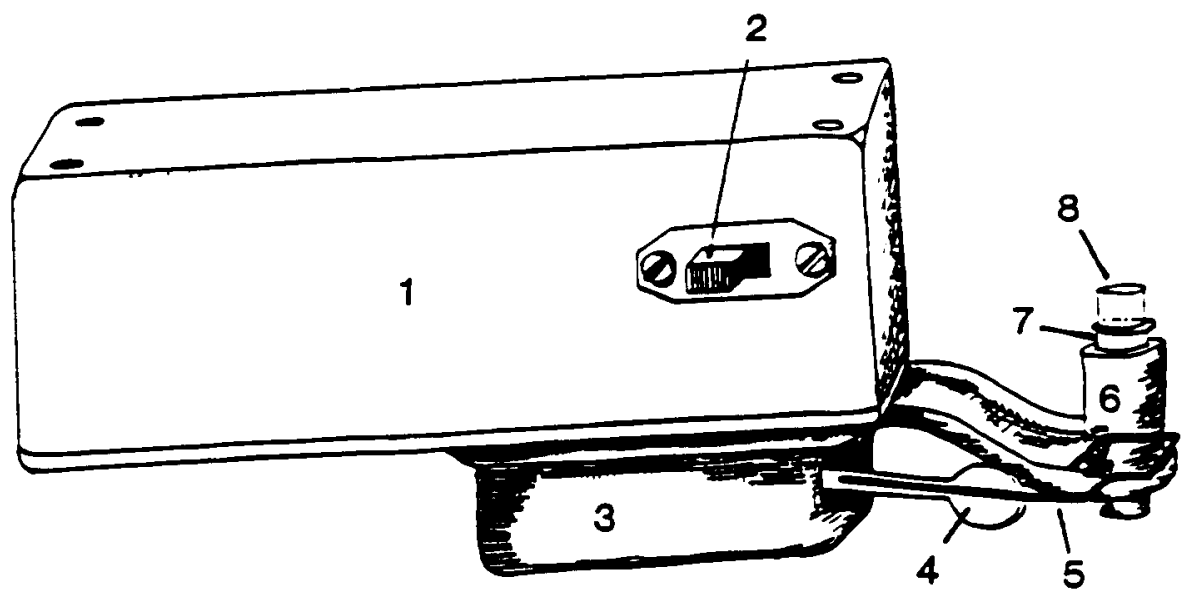

Figure 2. Vibratory collector for tomato pollen, modified from Rick (1980). Four " $C$ " batteries within the battery box (1) are wired in series to an on/off switch (2) and a doorbell ringer (3). A bent paper clip (5) is attached to the bell ringer arm (4) with silicone caulk. The bell is replaced by surgical tubing (6) that has paper balling in the end that is screwed to the bell ringer. In the upper end of the tubing is a micropipet tip (7) that is the diameter of a $\# 0$ gelatin capsule (8). Pollen is collected by placing the anther cone of a flower into a capsule held within the micropipet tip and completing the circuit. The capsule and flower are vibrated, releasing pollen into the capsule. 
Female plants were emasculated and then pollinated as described by Rick (1980), and each pollinated flower was labeled to show pollination parentage and date.

Seeds and pulp were extracted from mature fruit, and fermented (Rick, 1980). Seeds were then cleaned, dried and bulked by pedigree. All seeds were stored at room temperature in labeled paper envelopes.

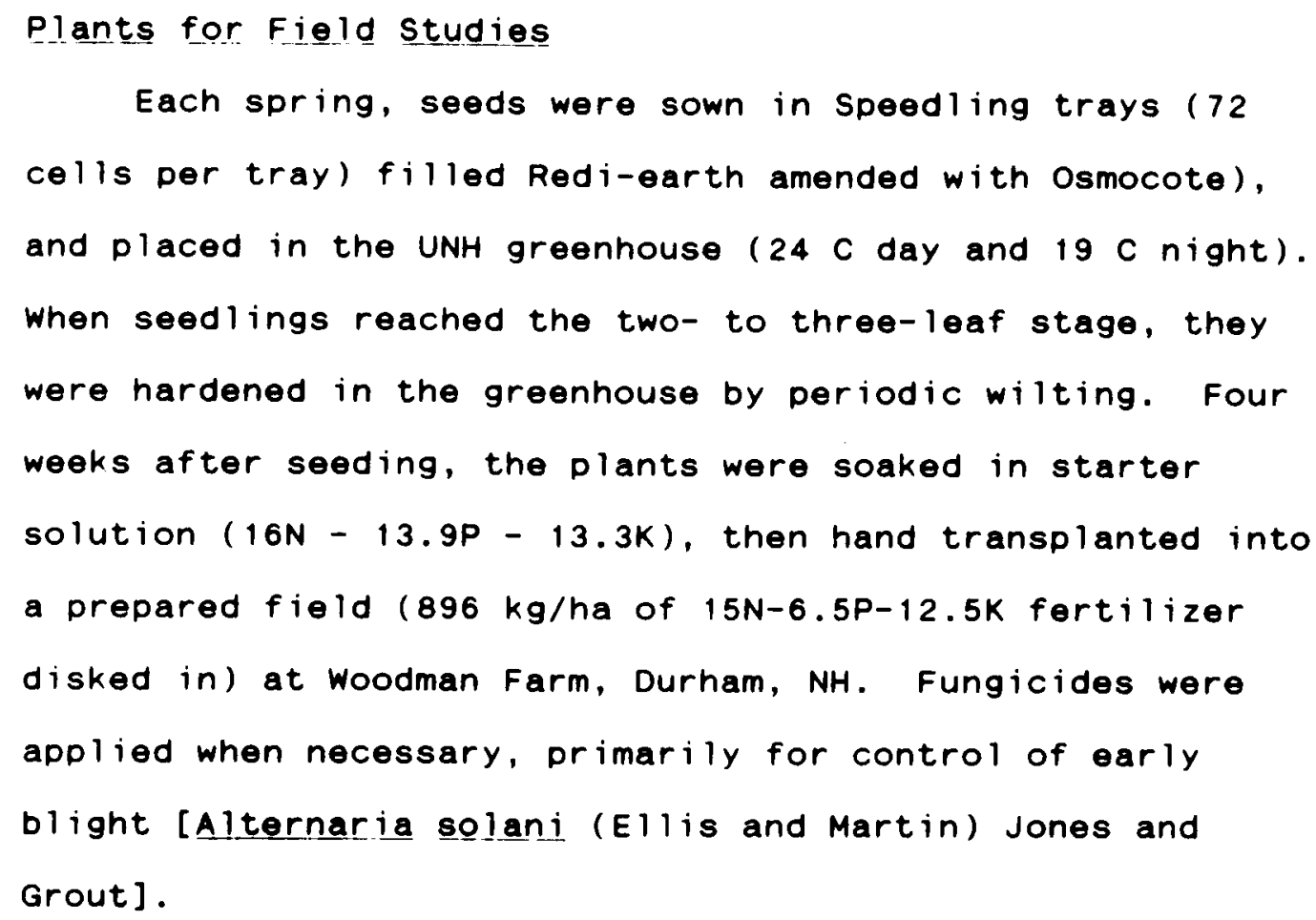

\section{Statistical Analyses and Graphs}

Data were analyzed using the computer program MSTAT, MS-DOS version 4.0 (Freed et a1., 1985). Graphs were drawn with Cricketgraph, Macintosh version 1.2. 
In Vitro Pollen Germination and Pollen Tube Growth of Early and Late Maturing Tomato Cultivars

\begin{abstract}
The procedures used for Experiments 1 and 2 were adapted from Maisonneuve and Den Nijs (1984), and Zamir et a). (1981).

Experiment 1. A 24-Hour In vitro study of Pollen Germination and Pollen Tube Growth at Three Temperatures In September, 1987, nine seedlings each of 'Gemstate', 'Rocket', 'Crimsonvee', and 'Harvestvee', and three seedlings each of 'Earlirouge' and 'Bellstar' were grown in the greenhouse (24 C day and $19 \mathrm{C}$ night) as described under "General Procedures". Each was then transplanted into a 25 $\mathrm{cm}$ diameter plastic pot and grown to flowering.

Pollen was collected from each cultivar as previously described, and applied with a $5 \mu l$ orummond microcap apparatus (Drummond Scientific Co.) to a medium composed of $18 x$ sucrose, 1x agar, and $0.015 x$ boric acid, adjusted to $\mathrm{pH}$ 6.00. The autoclaved medium was poured into six-well tissue culture dishes (Nunc, Inc., Naperville, IL), and pollen was plated, one cultivar to a wel1, $0.15 \mu l$ of pollen per well, at room temperature (approximately $22 \mathrm{C}$ ). The dishes then were incubated in dark growth chambers, simultaneously, at 8,15 , or $25 \mathrm{C}$ for $6,12,18$, or 24
\end{abstract}




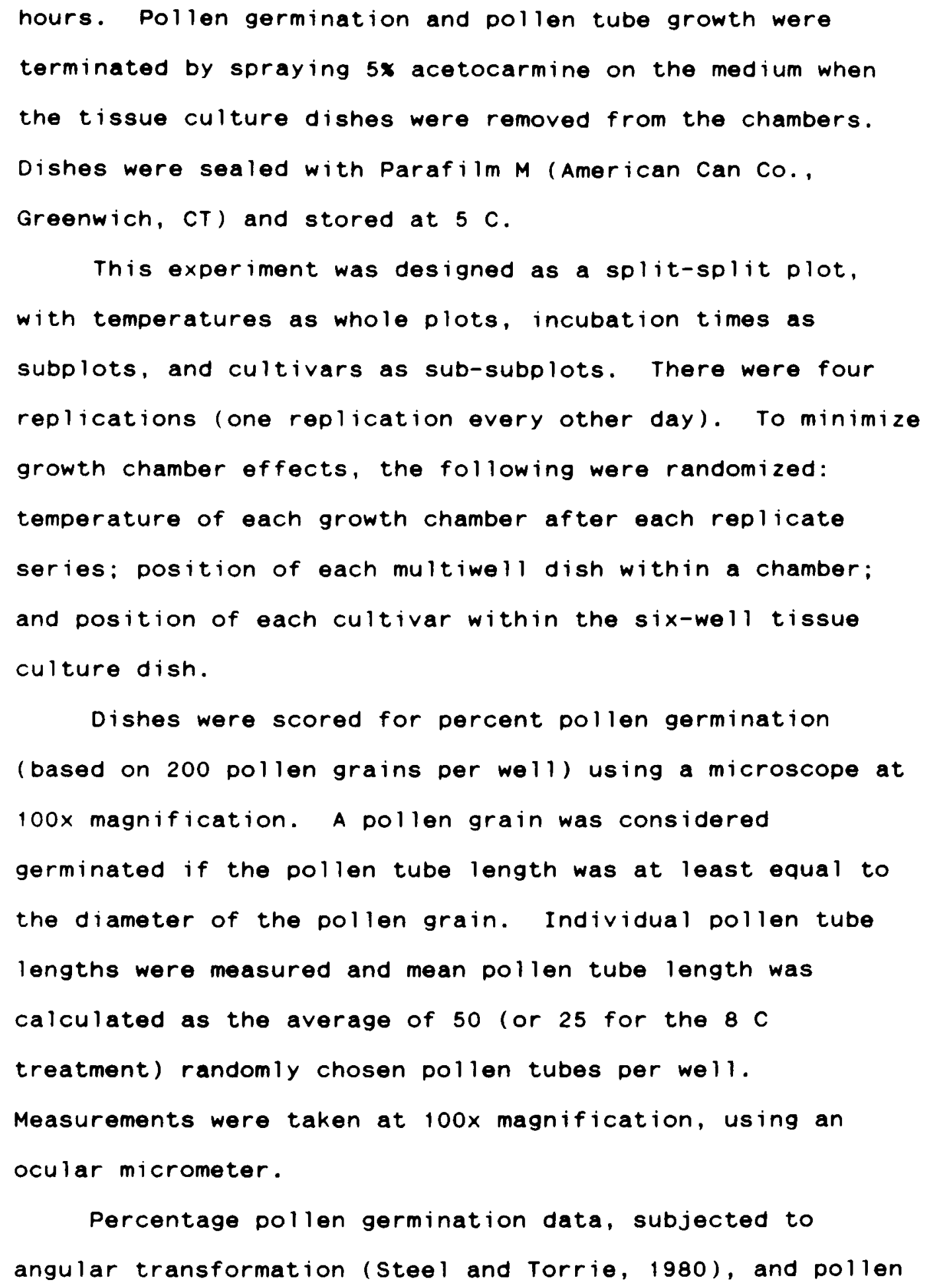


tube lengths were analyzed by analysis of variance.

Experiment 2. In Vitro Temperature Gradient study of Pollen Germination and Pollen Tube Growth

In August, 1990, four seedlings each of 'Gemstate'. 'Rocket', 'Crimsonvee', and 'Harvestvee' were grown in the greenhouse ( $29 \mathrm{C}$ day and $24 \mathrm{C} n i g h t$ ), and each was then transplanted into a $25 \mathrm{~cm}$ diameter plastic pot.

Pollen was collected from each cultivar as previously described and was applied with a $5 \mu l$ Drummond microcap apparatus (Drummond Scientific Co.), on the medium used for Experiment 1 , in LabTek four-chamber tissue culture slides (Nunc, Inc., Naperville, IL). Before pollen application, slides containing medium were preincubated at their respective treatment temperatures for 42 hours. Pollen from each cultivar then was plated, one cultivar to a chamber, $0.15 \mu 1$ of pollen per chamber, on eight duplicate fourchamber slides. The slides were placed within a temperature gradient device (Figure 3 ) in a dark growth chamber. The temperature gradient device was calibrated to provide treatment temperatures ranging from 10 to $16 \mathrm{C}$. Pollentreated slides were removed from the gradient device after three (three slides) or six (five slides) hours of incubation. Pollen germination and pollen tube growth were terminated by spraying $5 \%$ acetocarmine on the medium when the slides were removed from the gradient device. Slides 


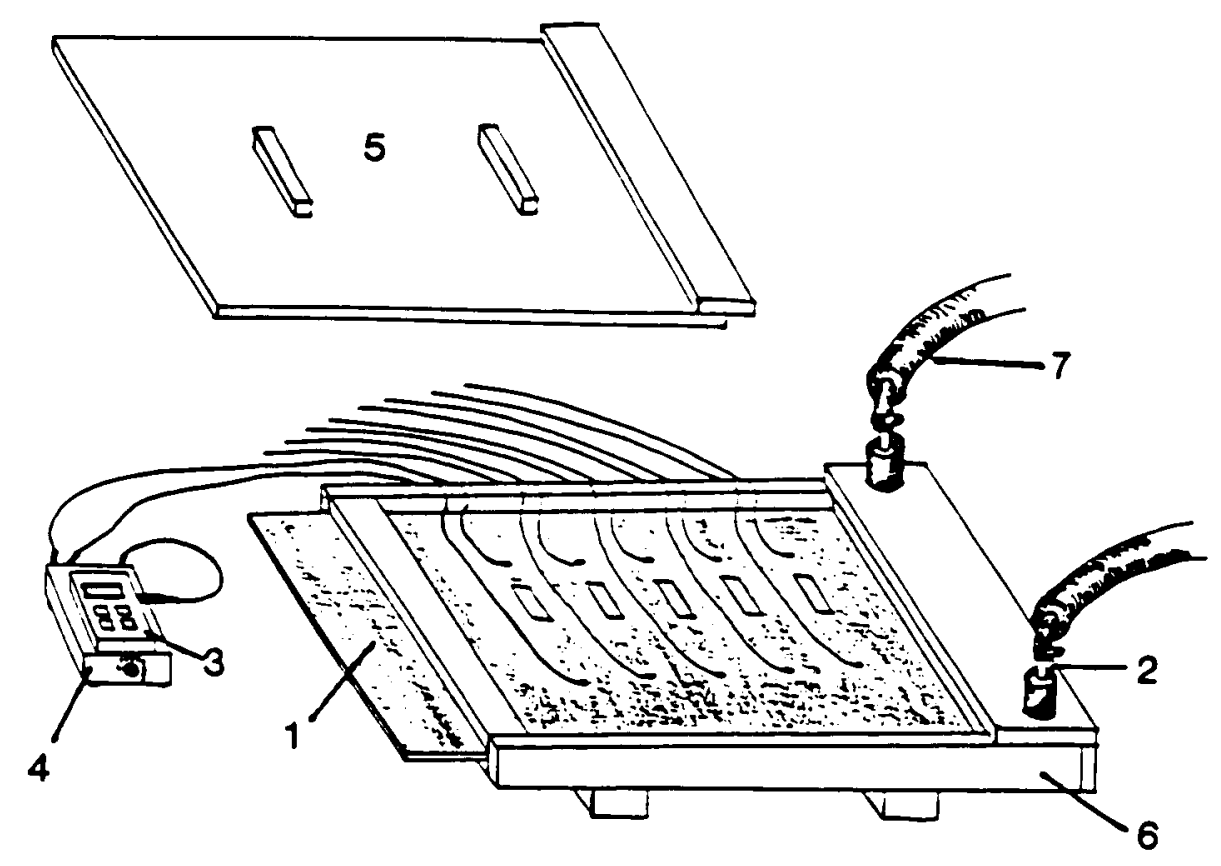

Figure 3. Temperature gradient device, modified from Chatterton and Kadish (1969) and Hensley et al. (1982). The device was placed inside a growth chamber. Chamber temperature controlled temperature of the exposed end of the $122 \mathrm{~cm} \times 51 \mathrm{~cm} \times .635 \mathrm{~cm}$ aluminium plate (1). At the opposite end of the plate, an enclosed water bath provided energy transfer between the aluminium plate and the temperature-controlled $1.27 \mathrm{~cm}$ diameter copper tubing (2). The copper tubing was connected, via $13 \mathrm{~mm}$ ID Buna $N$ tubing, to a refrigerated circulating water bath located outside of the growth chamber. The temperature gradient was established by adjusting the minimum (temperature of the chamber) and the maximum (temperature of the circulating bath) temperatures of the desired gradient. The temperature gradient across the plate was monitored by ten thermistor surface probes (model YSI409A, YSI, Inc., Yellow Springs, $\mathrm{OH}$ ) connected to an electronic digital thermometer (3) via a ten probe benchtop thermistor switchbox (4)(Cole-Parmer Instrument Co., Chicago, IL). The gradient cover (5) and the plate insulation (6) was made of $2.54 \mathrm{~cm}$ thick rigid foam, assembled with silicone caulk. The copper and Buna $N$ tubing were insulated with $1.27 \mathrm{~cm}$ thick foam rubber tubing insulation (7). 


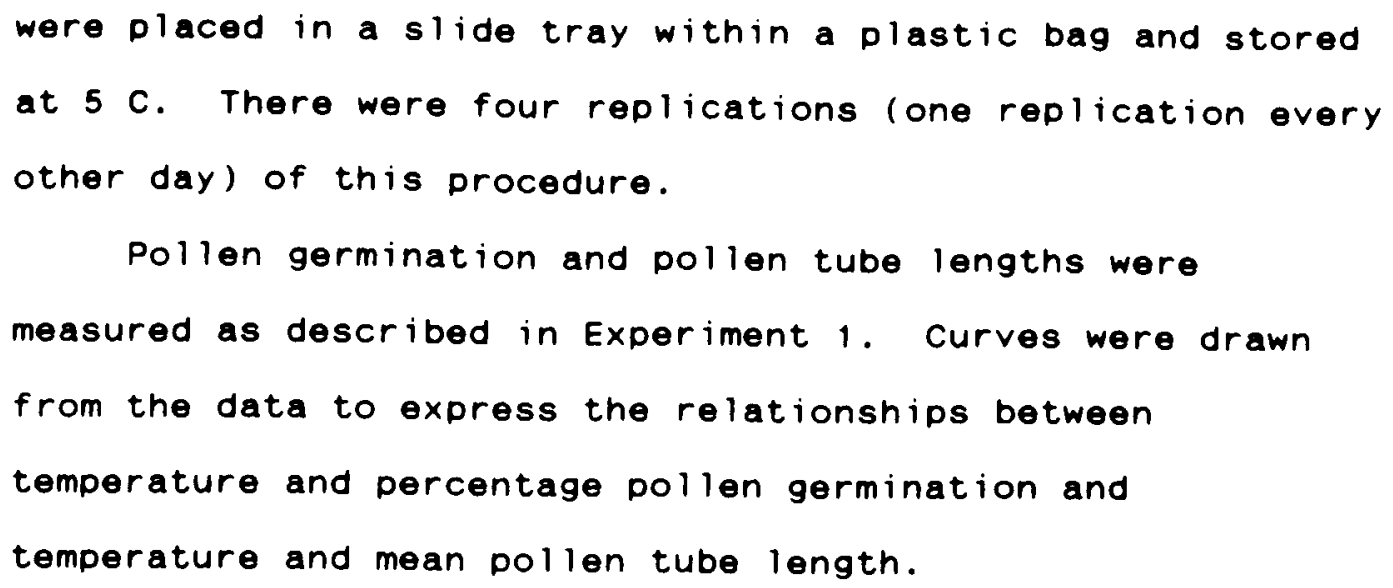


returned to the NFES greenhouse and the remaining six were placed in the chambers for the second pollination series. Conditions in one growth chamber were set at 12 hour cycles of $25 \mathrm{C}$ day (1ight period) and $20 \mathrm{C}$ night (dark period). The photosynthetically active radiation was approximately $200 \mu \mathrm{mol} \mathrm{s}^{-1} \mathrm{~m}^{-2}$, and relative humidity was approximately 50x. The second chamber had an identical time cycle, light intensity, and relative humidity, but was maintained at $15 \mathrm{c}$ (1 ight) and $10 \mathrm{C}$ (dark). Both chambers had a temperature variation of $\pm 1 \mathrm{C}$.

The nine plants of each pollen donor were maintained in the UNH greenhouse. For each series of crosses, pollen was collected from these donor plants, as described under "General procedures", and applied to females in the growth chambers. The types of crosses in each of the two pollination series are listed in Table 2 .

One, two, three and four days after initiating a pollination series, two pistils per cultivar cross, per chamber, were harvested, fixed, stored and stained as described in Figure 4. Pistils were squashed between coverslip and slide as described by Martin (1959). Evaluations of pollen germination and measurements of pollen tube length were made by observing slides under UV illumination ( $\mathrm{hv}=360 \mathrm{~nm}$ ) with a Leitz Orthomat microscope. Pollen germination per pistil was classified in the following manner: no germination; low germination (less than 
Table 2. Crosses made in each growth chamber for Experiments 3.1 and 3.2 .

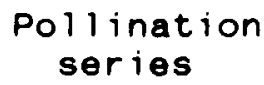

3. 1

\section{Experiment'}

3.2

1

$E \times G$
$B \times G$
$E \times R$
$B \times R$

$E \times G$

$B \times C$

$E \times H$

$B \times H$
$E \times C$

$B \times G$

$E \times C$

$B \times C$

2
$E \times R$

$B \times R$

$E \times H$

B $\times \mathrm{H}$

1 Parental cultivars designated as follows: Gemstate (G); Rocket (R); Earlirouge (E); Bellstar (B); Crimsonvee (C); and, Harvestree (H). 


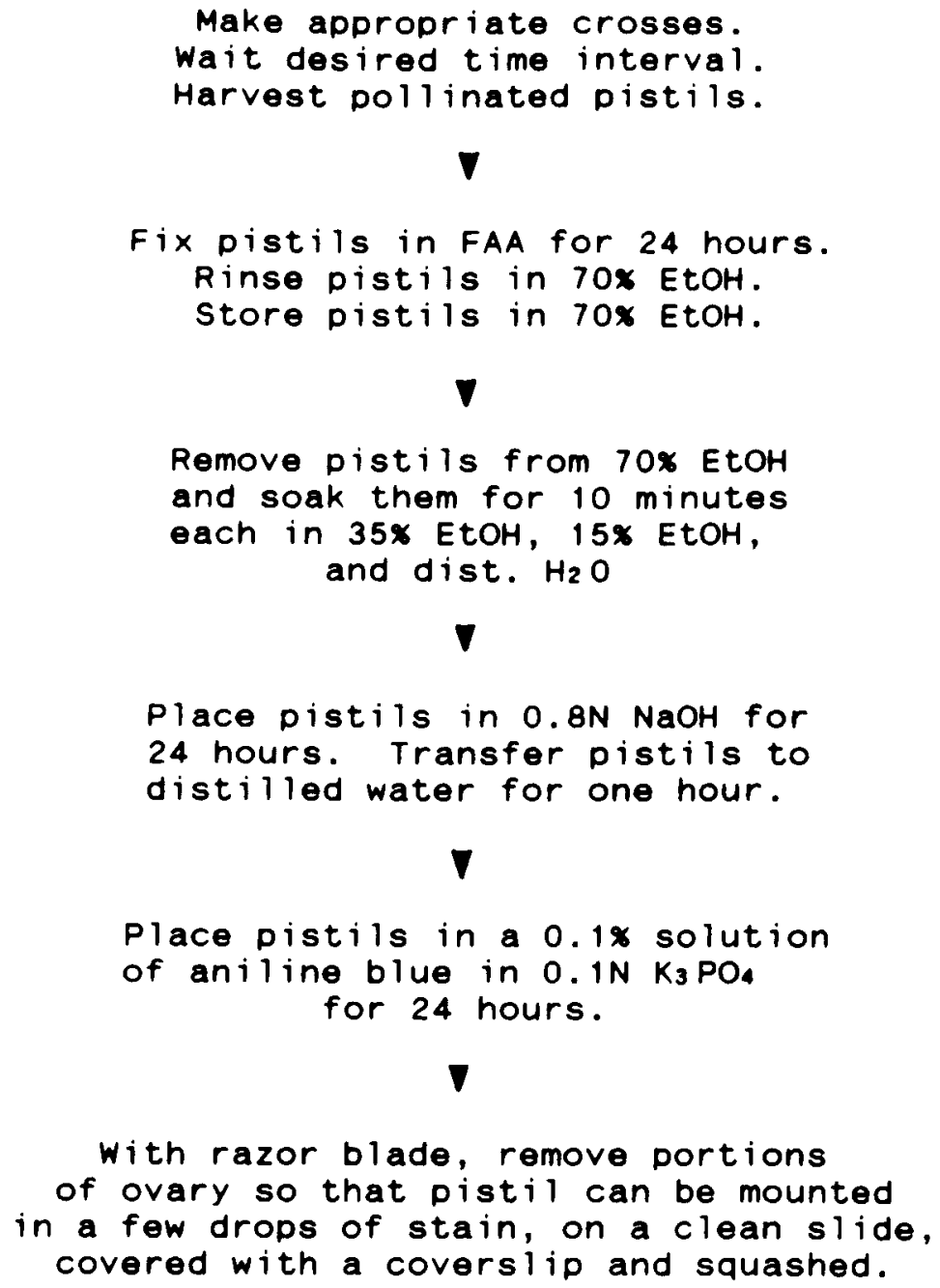

Figure 4. Staining procedure for Experiment 3, modified from Martin (1959). See Martin (1959) for solution recipes. 
Table 3. Procedural differences between Experiments 3.1 and 3.2 .

Procedure

Experiment
3.2
Date of greenhouse seeding

Greenhouse temperature (day / night)

Plants of each pollen donor cultivar

Plants of each female parent cultivar

Pot diameter for female parent plants $(\mathrm{cm})$

Date of pollination events

No. plants per female parent cultivar per chamber

Chamber 1 ight intensity (PAR: umol $\mathrm{s}^{-1} \mathrm{~m}^{-2}$ )

Temperature variation within low-temperature chamber
3. 1
$8 / 90$

$24 c / 19 c \quad 29 c / 24 c$

9

4

12

16

25

20

$\begin{array}{ll}2 / 88 & 11 / 90\end{array}$

3

4

200

$200-400$

$\pm 1 C$

$\pm 2 C$ 
10 tubes per pistil): intermediate germination (10 to 30 tubes per pistil): and high germination (more than 30 tubes per pistil). Pollen tube lengths were measured for the 10 longest tubes by determining the average length of the tubes relative to the length of the style. Pollen tube lengths were designated as $1 / 4,1 / 2,3 / 4$, or full length styles. All observations were made at $100 \times$ magnification.

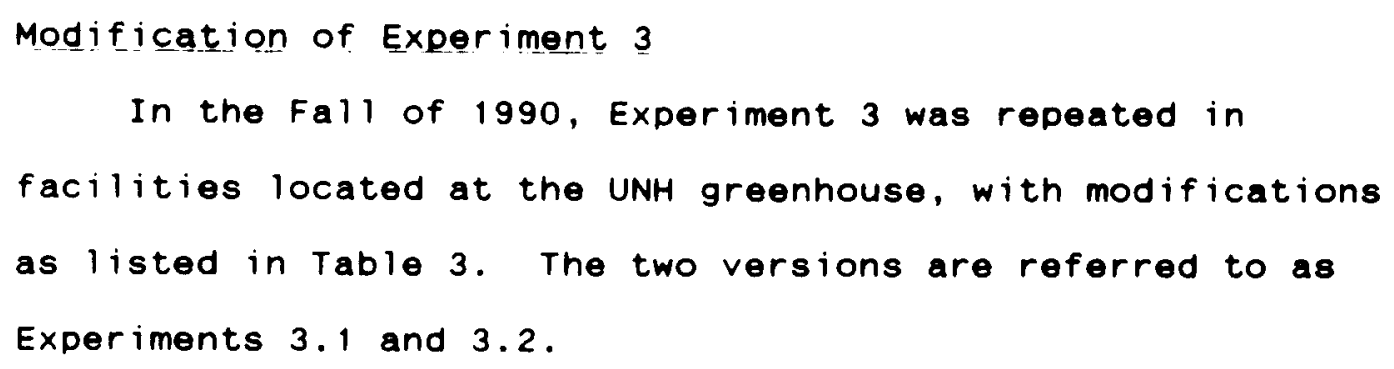


In September, 1987, nine seedlings of each pollen-donor cultivar and 30 seedlings of each female-parent cultivar were grown in the UNH greenhouse ( $24 \mathrm{C}$ day and $19 \mathrm{C}$ night) as described under "General Procedures". Each seedling was transplanted into a $25 \mathrm{~cm}$ diameter plastic pot. The 60 female parent plants then were transferred to the NFES greenhouse ( $24 \mathrm{C}$ day and $19 \mathrm{C}$ night).

When female parent plants were 45 to $60 \mathrm{~cm}$ in height, six of each female parent cultivar were moved to two growth chambers located in the main building of the NFES, three plants per cultivar per growth chamber. When pollinations were completed, the six plants were moved back into the greenhouse, and another six were brought to the chambers to be pollinated. This six-plant cycling continued until each female parent plant was pollinated. Conditions in one growth chamber were set at 12 hour cycles of $25 \mathrm{C}$ day (1ight period) and $19 \mathrm{C}$ night (dark period). Photosynthetic photon flux (PPF) was $200 \mu \mathrm{mol} \mathrm{s}^{-1} \mathrm{~m}^{-2}$. The second chamber was set at an identical time cycle and PPF but was maintained at 15 C (1ight) and $10 \mathrm{C}$ (dark). Both chambers were set at approximately $50 \times$ relative humidity and had a temperature variation of $\pm 1 \mathrm{C}$.

The nine plants of each pollen donor cultivar were maintained in the UNH greenhouse. Pollen was collected from these plants, and six different pollen mixtures were prepared representing equal volumes of pollen harvested from 
any two of the four cultivars, and thoroughly mixed with the vibratory pollen collector. Pollen mixtures were used immediately after preparation.

Female parents were emasculated and pollinated as previously described. The types of crosses made with pollen mixtures, in each growth chamber, are 1 isted in Table 4 . In addition, crosses were made with unmixed pollen in the UNH greenhouse as a control: these crosses are listed in Table 4. Enough flowers were pollinated to provide an adequate amount of $F_{1}$ seed per cross. Natural selfing of two flowers per cultivar was allowed to take place to obtain parental seed.

Forty-eight hours after pollination, plants were moved from the growth chambers to the NFES greenhouse. Immediately after removing plants from the growth chambers, styles of flowers receiving a pollen mixture were cut at midlength with a sterile razor blade to prevent late fertilizations under subsequent greenhouse conditions (24 C day and 19 ( night).

Only three fruits were set on all plants pollinated at low temperature resulting in an insufficient amount of seed for the planned field trials. To salvage some aspect of this experiment, the harvested fruits of normal-temperature pollinations were sliced into two portions, with $2 / 3$ of the fruit at the receptacle end, $1 / 3$ of the fruit at the blossom end. Seeds were harvested from each portion and stored. 
Table 4. Crosses made for Experiments 4.1 and 4.2 .

Crosses'

Pollen mixture

Non-mixture

$E \times(G+R)$

$E \times(G+C)$

$E \times(G+H)$

$E \times(R+C)$

$E \times(R+H)$

$E \times(C+H)$

$B \times(G+R)$

$B \times(G+C)$

$B \times(G+H)$

$B \times(R+C)$

$B \times(R+H)$

$E \times G$

$E \times R$

$E \times C$

$E \times H$

$B \times(C+H)$

$B \times G$

$B \times R$

$B \times C$

B $\times \mathrm{H}$

1 Parental cultivars are designated as follows: Gemstate (G); Rocket (R); Earlirouge (E); Bellstar (B); Crimsonvee (C): and, Harvestree (H). 
Field Experiment. During Apri1, 1988, seeds were sown and seedings transplanted to speedling trays for eventual transplanting. After four weeks of growth, the plants were transferred to a field location arranged in five consecutive blocks of 30 plots each ( 30 plots wide by 1 plot long), surrounded by guard rows of tomato and eggplant. Each experimental plot consisted of a bed of double rows of five plants (ten plants per plot), spaced $0.45 \mathrm{~m}$ apart on black plastic mulch $(1 \mathrm{~m}$ wide and $38 \mathrm{\mu m}$ thick). Plots were $1.8 \mathrm{~m}$ apart on center. The entries are listed in Table 5.

Data were recorded on unripe fruit color (uniform or non-uniform) and ripe fruit color (oge oge or oge oge), the latter using light reflectance color determination on 2 fruits per plant (Watada et al., 1976). Data from progeny tests using seeds from blossom and receptacle ends of the fruit were compared for segregation of genetic markers, using the contingency Chi-square test (Strickberger, 1976).

\section{Modification of Experiment 4}

When Experiment 4 was attempted again in winter, $1989 / 90$, enough seed was obtained from the low temperature pollination treatment to plant a field experiment in summer, 1990, with the modifications as listed in Table 6 . This version is referred to as Experiment 4.2 and the version referred to as Experiments 4.1 compared segregation of genetic markers in the blossom and receptacle ends of 
Table 5. Entries planted in Field Experiments 4.1 and 4.2 .

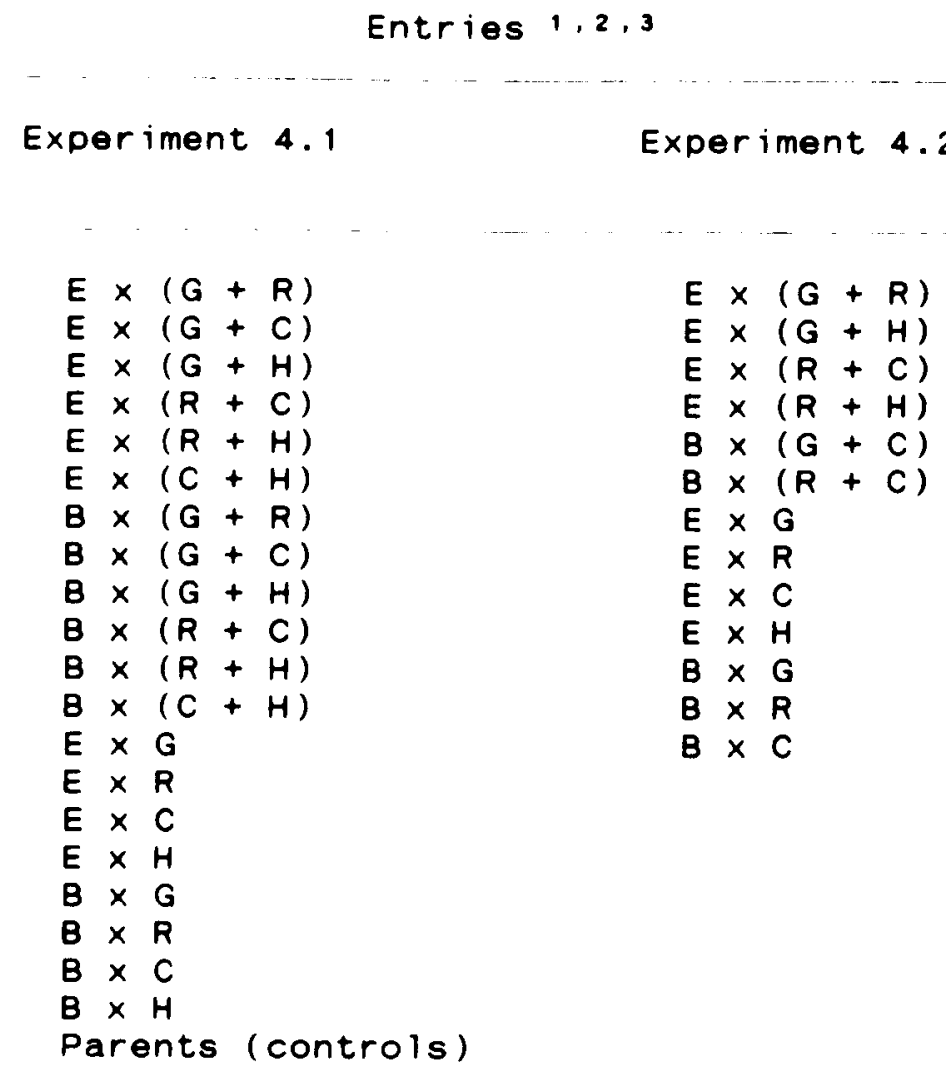

\footnotetext{
1 There were two populations for every pollen mixture entry for Experiment 4.1. One population was derived from seed located in the blossom end of the fruit and the other population was derived from seed located in the receptacle end of the fruit.

2 There were two populations for every pollen mixture entry in Experiment 4.2. One population was derived from the lowtemperature pollination treatment (15 C light/ $10 \mathrm{C}$ dark) and the other population was derived from the normaltemperature pollination treatment (25 C light/ $20 \mathrm{C}$ dark).

3 Parental cultivars are designated as follows: Gemstate (G): Rocket (R); Earlirouge (E); Bellstar (B); Crimsonvee (C); and, Harvestree (H).
} 
Table 6. Procedural differences between Experiments 4.1 and 4. 2

Procedure

\section{Experiment}

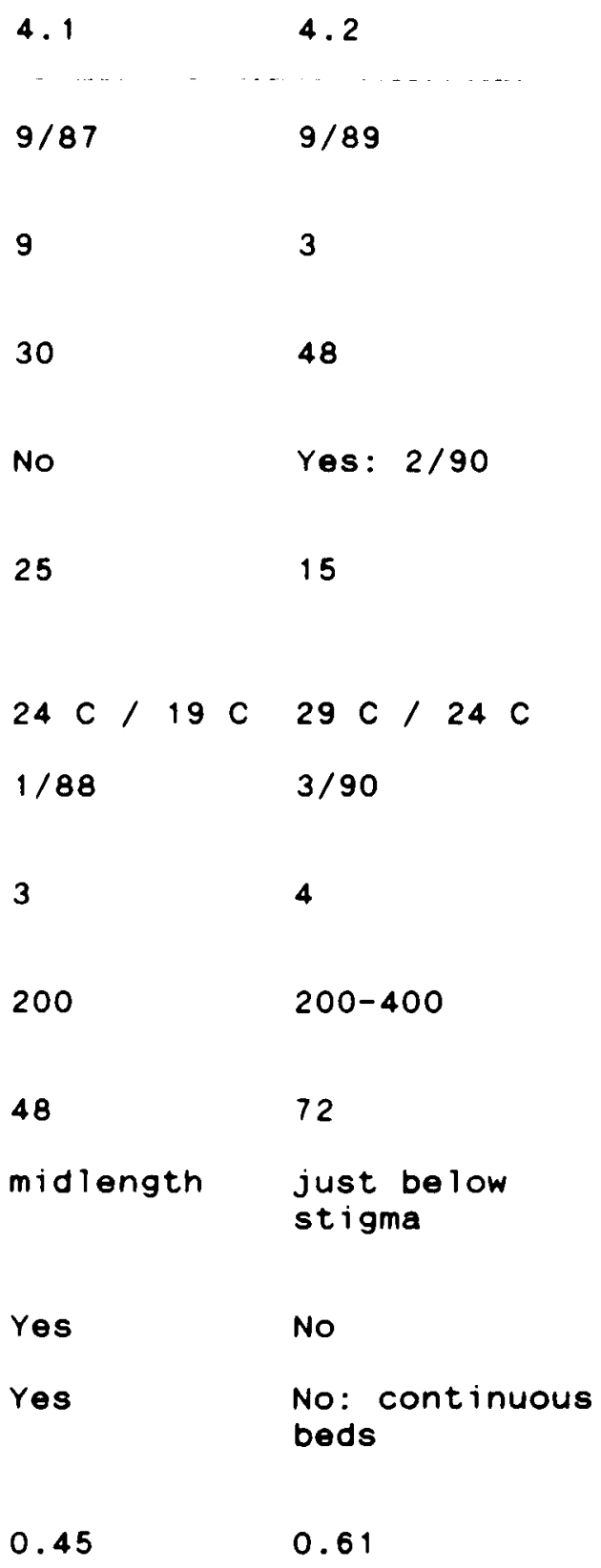


harvested fruit.

\section{Selective Self-Fertilizations of F, Hybrids of Early and \\ Late Maturing Tomato Cultivars.}

Experiment 5

Selective Self-Fertilizations. During October, 1988 , eight seedlings of each $F_{1}$ hybrid (Table 7 ) were grown in the UNH greenhouse at $24 \mathrm{C}$ day and $19 \mathrm{C}$ night). Each seedling was transplanted into a $20 \mathrm{~cm}$ diameter plastic pot. When plants were 45 to $60 \mathrm{~cm}$ in height, eight plants each of two $F_{1}$ hybrids were placed in two growth chambers (environmental settings as described for Experiment 4.2), four plants per hybrid per growth chamber. When the pollination treatment was completed, these 16 plants were moved back to the greenhouse and another 16 plants leight plants each of two other $F_{1}$ hybrids) were brought to the chambers to be pollinated. This two-hybrid cycling continued until all Fi hybrid plants had been pollinated. Pollen was collected from each plant to be pollinated, and these plants also were emasculated. Fresh self-pollen then was applied to obtain $F_{2}$ seeds (see "General Procedures"). These hand-emasculations were made to insure against any self-pollination that may have occurred before the temperature treatment was applied. Enough flowers were 
Table 7. Fi hybrids self-pollinated under selective conditions in Experiments 5.1, 5.2, and 5.3.

\section{Experiment no.1}

5.1 and 5.2
$G \times R$
$G \times C$
$G \times H$
$R \times G$
$R \times C$
$R \times H$
$C \times G$
$C \times R$
$C \times \mathrm{H}$
$H \times G$
$H \times R$
$\mathrm{H} \times \mathrm{C}$

5.3

$G \times R$

$G \times C$

$G \times H$

$R \times G$

$R \times C$

$\mathrm{R} \times \mathrm{H}$

$C \times G$

$C \times R$

$\mathrm{C} \times \mathrm{H}$

$H \times R$

$\mathrm{H} \times \mathrm{C}$

1 Parental cultivars are designated as follows: Gemstate (G); Rocket (R); Crimsonvee (C); and, Harvestvee (H). 
pollinated to provide an adequate amount of $F_{2}$ seeds per cross.

Seventy-two hours after pollination, plants were moved from the growth chambers into the greenhouse. Immediately after removing plants from the growth chambers, pollinated styles were cut at midlength with a sterile razor blade to prevent late fertilizations under greenhouse conditions ( 24 C day and 19 ( night). Seeds were harvested from ripe fruit and stored.

Field Experiment. In May, 1989, F2 seeds were sown and eventually transplanted as described under "General Procedures". The plants were transferred to an experimental area that was divided into four consecutive blocks, each of which contained 24 randomized plots $(24$ plots wide by 1 plot long). Eggplant and tomato guard rows surrounded the experiment. Each experimental plot consisted of staggered, double rows of 10 plants (20 plants per plot), spaced $0.61 \mathrm{~m}$ apart on beds mulched with black plastic $(1 \mathrm{~m}$ wide and $38 \mathrm{\mu m}$ thick). Plots were $1.8 \mathrm{~m}$ apart on center. The experimental plot entries are 1 isted in Table 8. The dates of first flower (anthesis) and first ripe fruit (breaker stage) were recorded for each plant in each plot. Dates of first flower and first ripe fruit were converted to days from seeding. Summary statistics were calculated for each plot, and frequency distributions were constructed for these data. Contingency Chi-squares 
Table 8. Entries planted in Field Experiments 5.1, 5.2, and 5.3.

$$
\text { Entries } 1,2
$$

Experiment 5.1

\begin{tabular}{|c|c|c|c|c|}
\hline G & $x$ & $\mathbf{R}$ & $F_{2}$ & , $F_{1}$ \\
\hline G & $x$ & $C$ & & $"$ \\
\hline G & $x$ & $H$ & $"$ & , " \\
\hline $\mathbf{R}$ & $x$ & $\mathbf{G}$ & $"$ & , " \\
\hline$R$ & $x$ & C & $"$ & " \\
\hline$R$ & $x$ & $H$ & $"$ & $"$ \\
\hline C & $x$ & $\mathbf{G}$ & $"$ & , \\
\hline C & $x$ & $\mathbf{R}$ & $"$ & $"$ \\
\hline H & $x$ & $\mathbf{G}$ & $"$ & $"$ \\
\hline$H$ & $x$ & $\mathbf{R}$ & $"$ & , \\
\hline$H$ & $x$ & C & $"$ & , " \\
\hline
\end{tabular}

\author{
Experiment 5.2
}

\begin{tabular}{|c|c|c|c|}
\hline G & $x$ & C & $F_{2}$ \\
\hline G & $x$ & $H$ & \\
\hline $\mathbf{R}$ & $x$ & G & $"$ \\
\hline $\mathbf{R}$ & $x$ & $C$ & " \\
\hline $\mathbf{R}$ & $x$ & $H$ & " \\
\hline C & $x$ & $\mathbf{G}$ & $"$ \\
\hline C & $x$ & $\mathbf{R}$ & " \\
\hline$H$ & $x$ & $\mathbf{G}$ & $"$ \\
\hline $\mathrm{H}$ & $x$ & $\mathbf{R}$ & $"$ \\
\hline
\end{tabular}

Experiment 5.3

Parents

1 There were two populations for every $F_{2}$ entry for Experiments 5.1, 5.2, and, 5.3. One population was derived from the low temperature self-pollination treatment ( $15 \mathrm{C}$ $1 \mathrm{ight} / 10 \mathrm{C}$ dark) and the other population was derived from the normal temperature pollination treatment ( $25 \mathrm{C} 1 \mathrm{ight} / 20$ ( dark).

2 Parental cultivars are designated as follows: Gemstate (G) ; Rocket (R); Crimsonvee (C); and, Harvestvee (H). 
(Strickberger, 1976) were used to compare frequency

distributions of populations derived from the two

pollination temperature treatments.

Modifications of Experiment 5

Experiment 5 was performed three times with procedural

modifications as listed in Table 9. The three versions are

referred to as Experiments $5.1,5.2$, and 5.3 . 

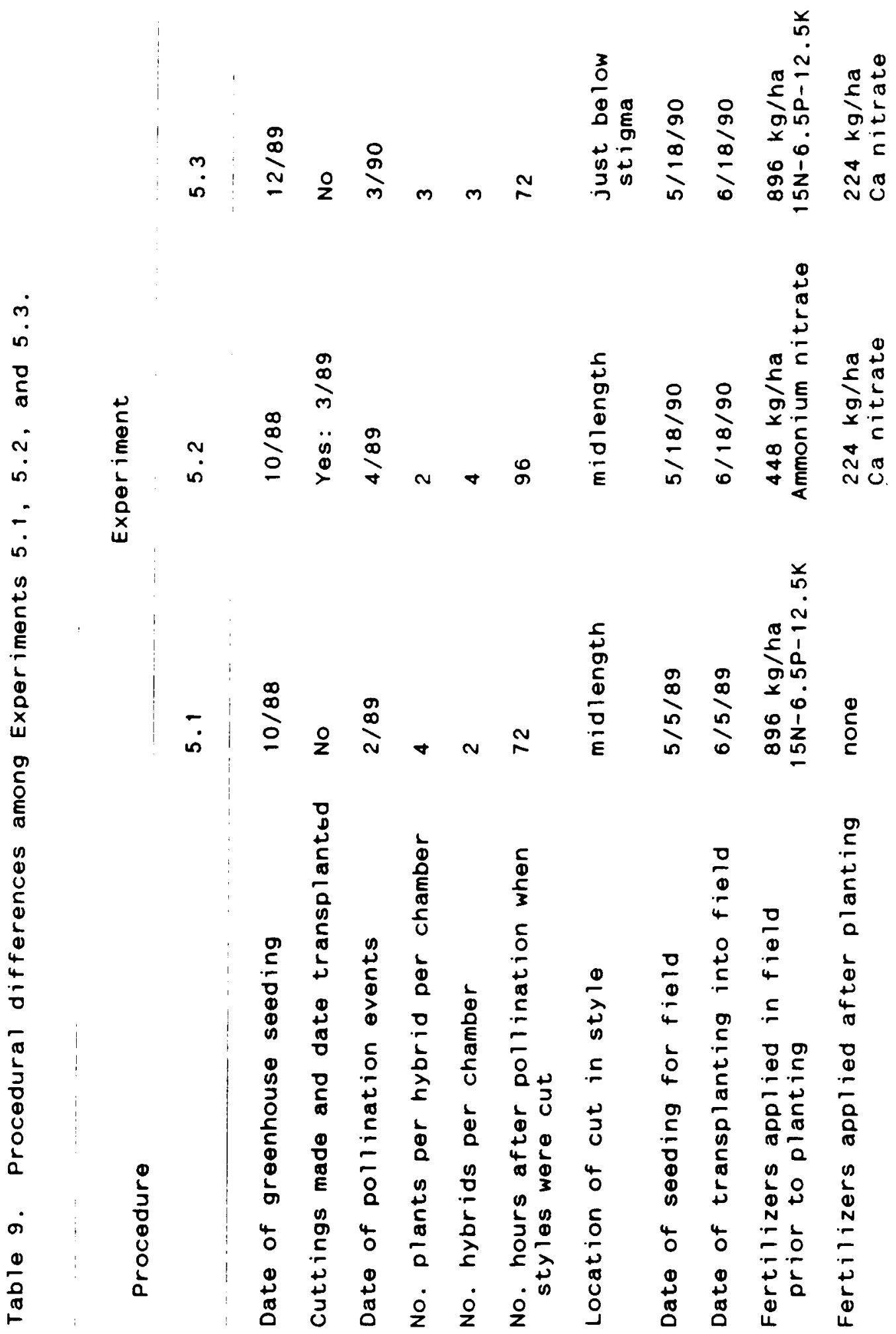


\section{RESULTS AND DISCUSSION}

In vitro Pollen Germination and Pollen Tube Growth of Early and Late Maturing Tomato Cultivars.

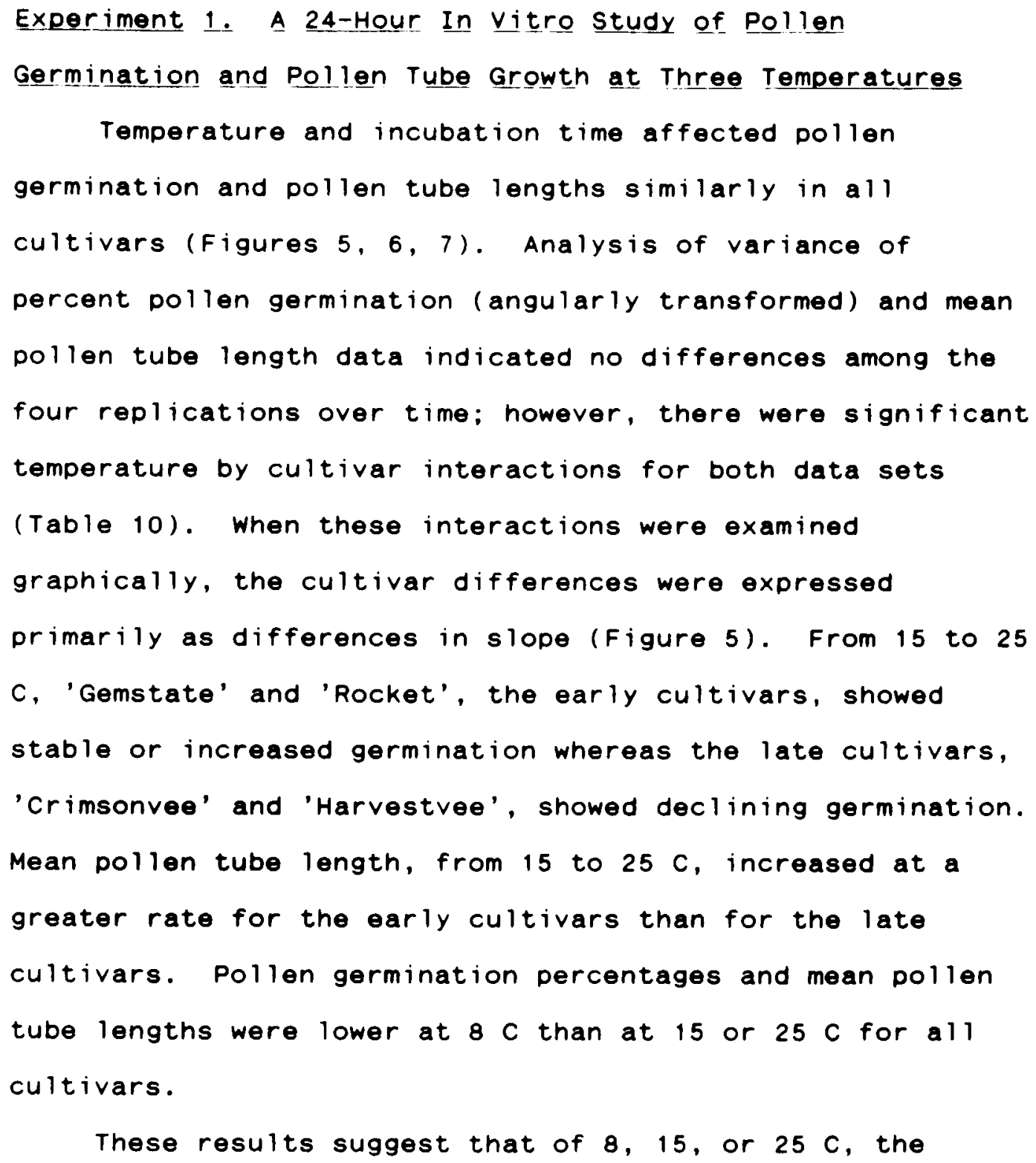



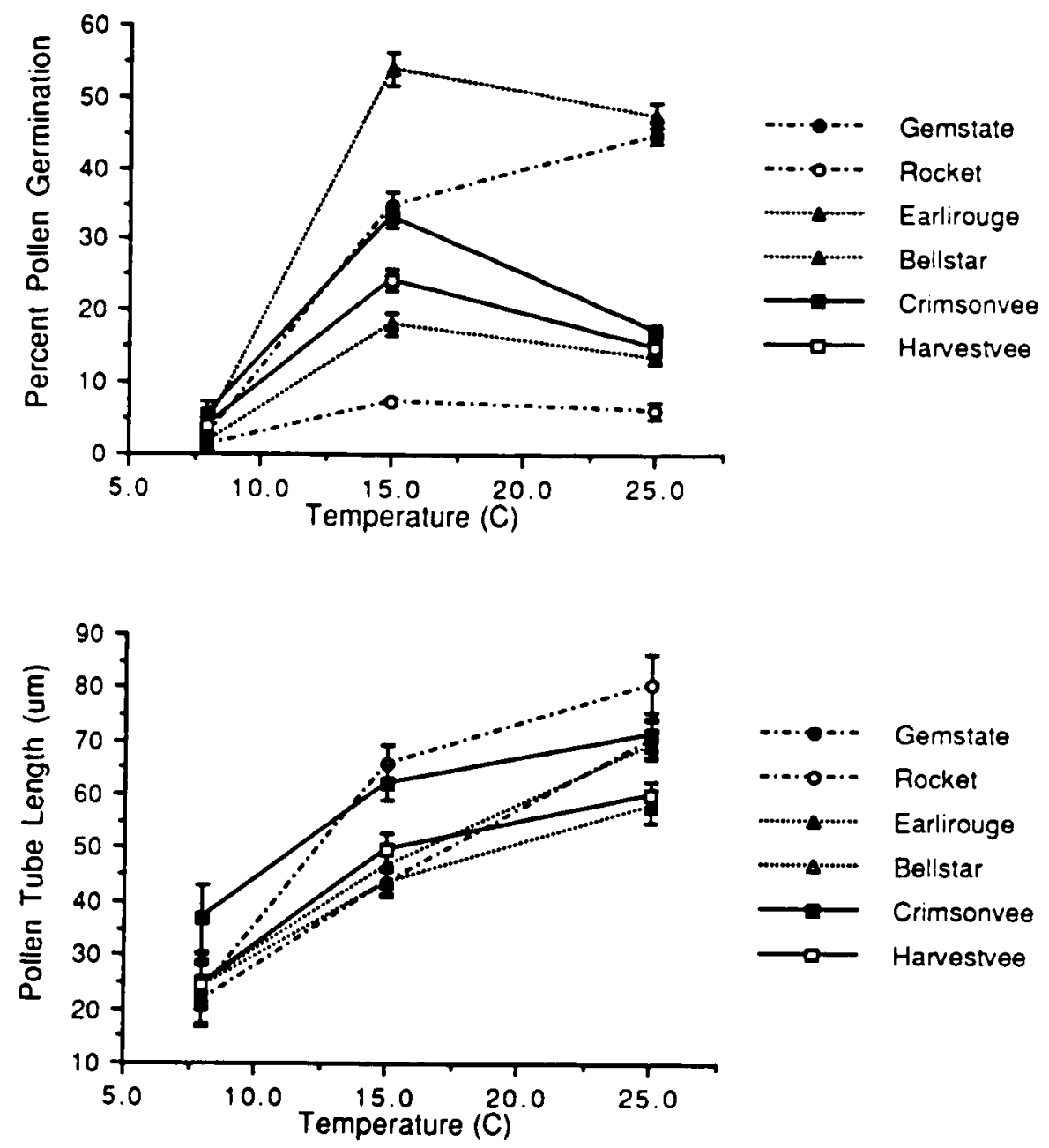

Figure 5. Temperature by cultivar interactions for (too) percent pollen germination and (bottom) mean pollen tube length. Each data point \pm SE represents a mean of four replications and four incubation times. 

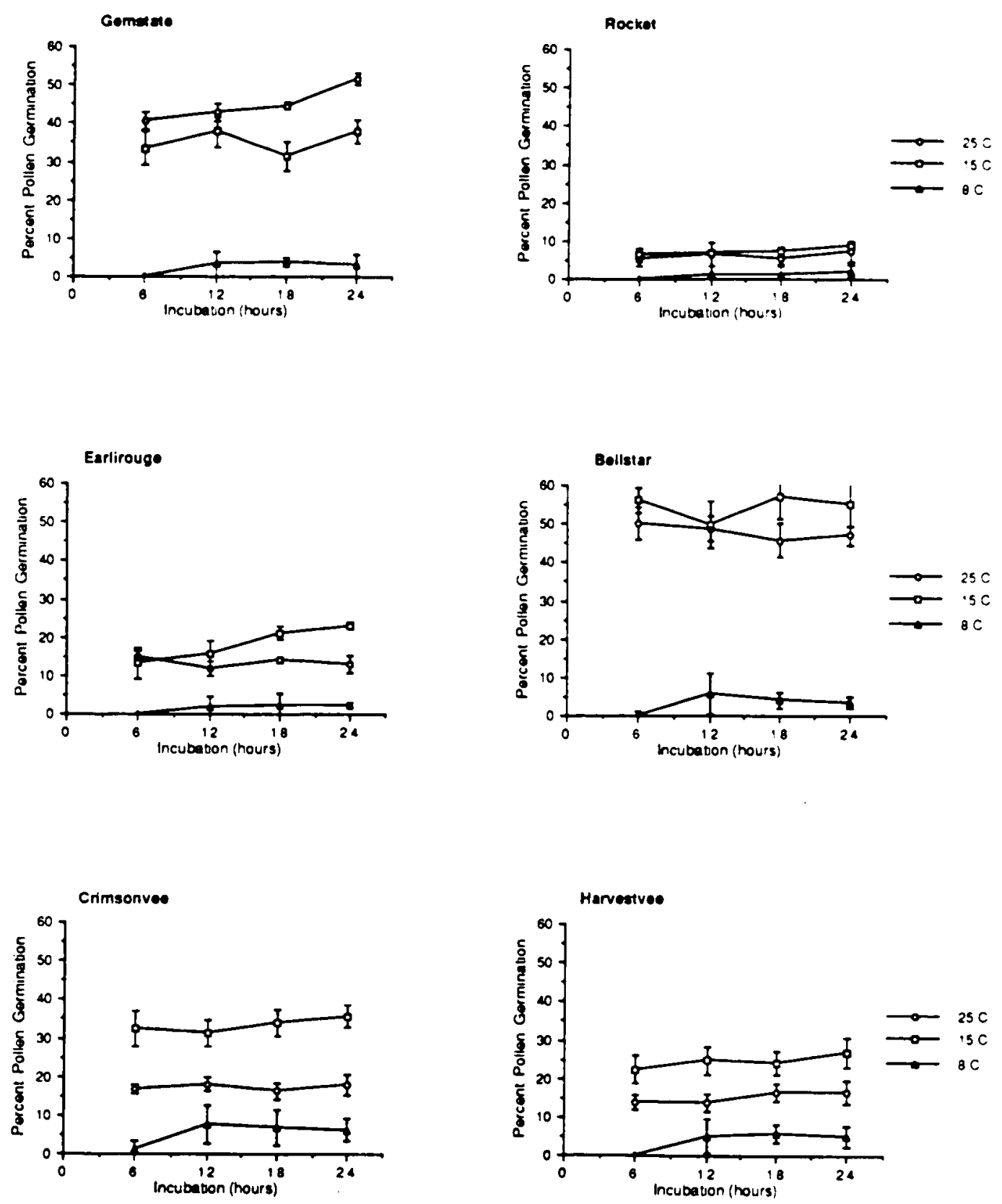

Figure 6. Percent pollen germination at three temperatures and four incubation times for six tomato cultivars. Each data point $\pm S E$ represents a mean of four replications.

47 

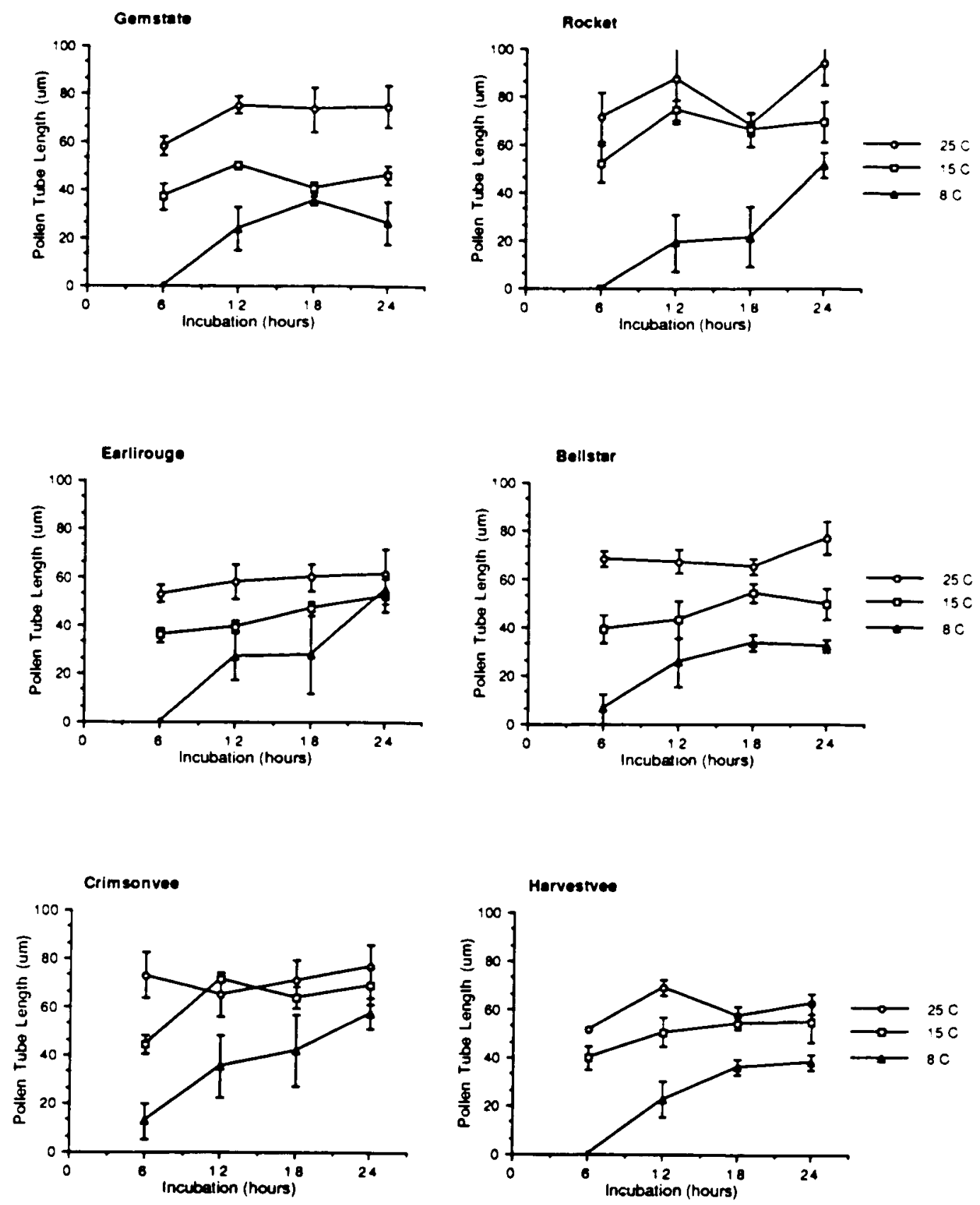

Figure 7. Mean pollen tube lengths at three temperatures and four incubation times for six tomato cultivars. Each data point \pm SE represents a mean of four replications. 
Table 10. Variances from analyses of percentages of pollen germination, and mean pollen tube lengths for six tomato cultivars.

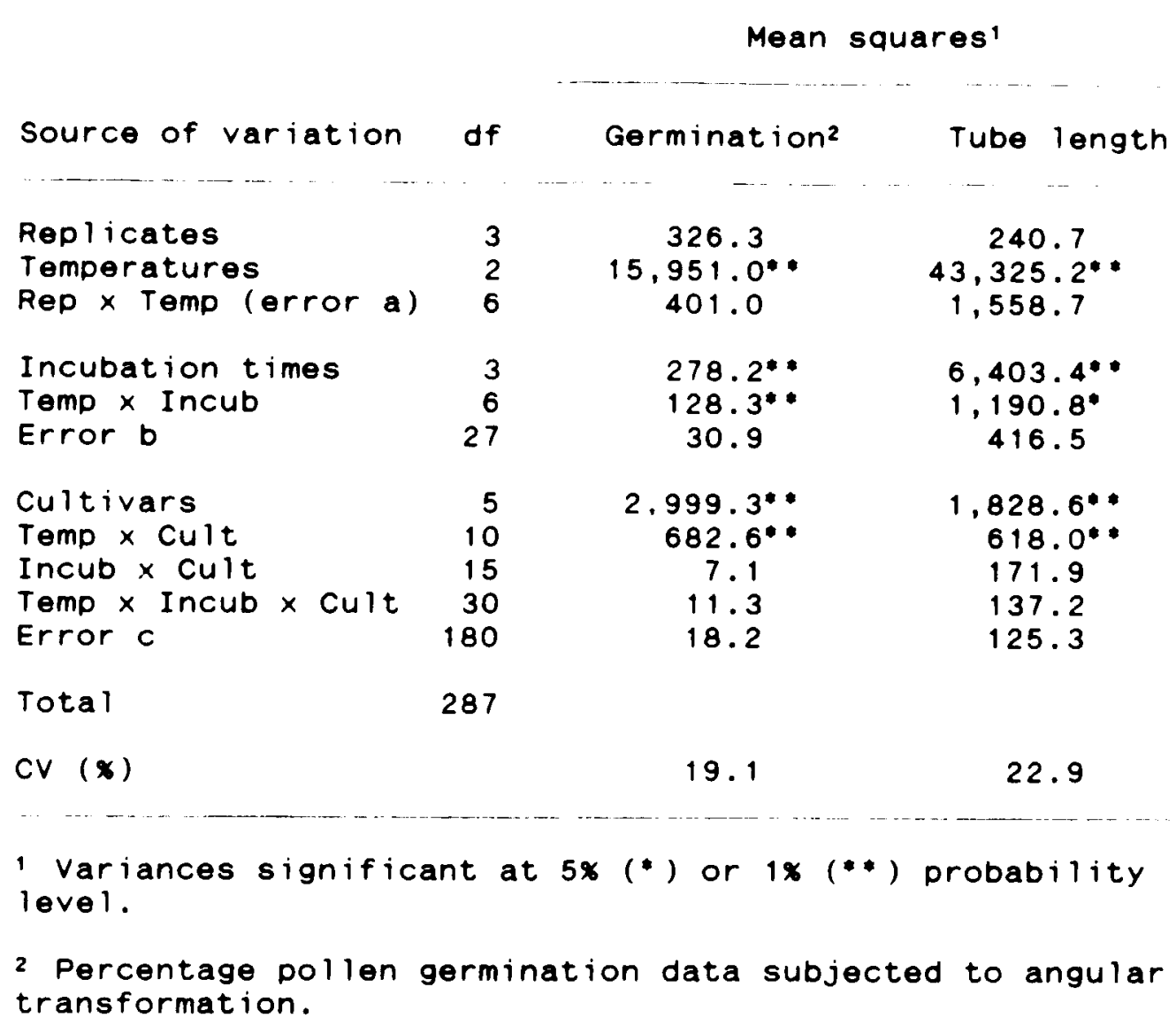


optimal temperature for in vitro pollen germination of 'Gemstate', an early cultivar, is $25 \mathrm{C}$ and optimal temperature for pollen germination of the late cultivars is 15 c. Dempsey (1970) reported that the optimal temperature for pollen germination was $25 \mathrm{C}$ for the 16 tomato cultivars and 1 ines that he tested. Other workers (Charles and Harris, 1972; Maisonneuve and Den Nijs, 1984) have found that the optimal temperature is closer to $15 \mathrm{C}$ for tomato pollen germination $(18.3 \mathrm{C}$ and $14.0 \mathrm{C}$, respectively). In any case, there appears to be variation among tomato cultivars with respect to optimal temperatures for in vitro pollen germination.

Growth of pollen tubes in this study appeared to be directly related to temperature as reported by Dempsey (1970), Charles and Harris (1972), and Maisonneuve and Den Nijs (1984), but there was variation among cultivars for rates of pollen tube growth at different temperatures as noted by Robinson and Echim (1988). This variation may be associated with early maturity, since the late cultivars had the lowest rates of tube growth from 15 to $25 \mathrm{C}$. However, this association between maturity type and rate of tube growth was not evident from 8 to 15 C (Figure 5).

A possible source of confounding in this test may have been applying pollen to dishes held at room temperature rather than preincubating the dishes at their respective treatment temperatures. A small-scale comparison where 
pollen was applied to dishes either held at room temperature or preincubated at designated temperatures, indicated that germination percentages for the 8 and $15 \mathrm{C}$ treatments were slightly inflated in the room temperature dishes (approximately 1.5 and 4.0 percentage points, respectively) and that there was no difference for the $25 \mathrm{c}$ treatment.

Experiment 2. An In vitro Temperature Gradient study of Pollen Germination and Pollen Tube Growth

The relationships between temperature and percent pollen germination, and between temperature and mean pollen tube growth were best described by a second degree polynomial for all cultivars, from data taken after three or six hours of incubation (Figures $8,9,10,11$ ).

After three hours of incubation, the relationship between temperature and percent pollen germination most closely fit a positive second degree partial regression coefficient (increasing slope) for 'Gemstate' (1.0924), 'Rocket' (1.0017), 'Crimsonvee' (1.3815), and 'Harvestvee' $(0.70554)$ (Figure 8 ). After six hours of incubation, the relationship between temperature and pollen germination was best described by a positive second degree partial regression coefficient for 'Gemstate' $(0.77697)$ and a negative second degree partial regression coefficient for 'Rocket' (-0.39024), 'Crimsonvee' (-1.4477), and 'Harvestvee' $(-0.9255)$ (Figure 9$)$. 

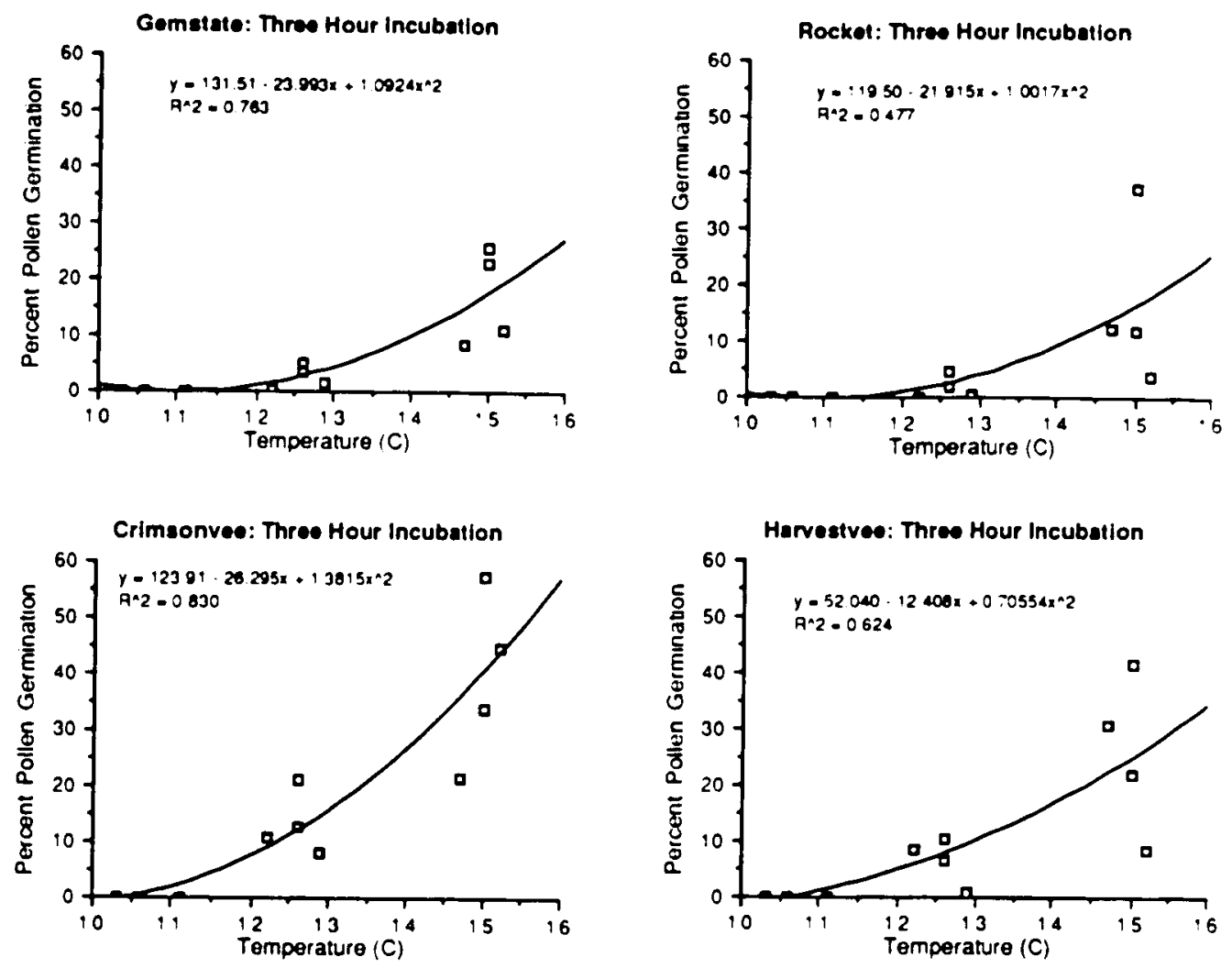

Figure 8. Relationship between temperature and percent pollen germination, after three hours of incubation, for four tomato cultivars. Data from four replicates are included. 

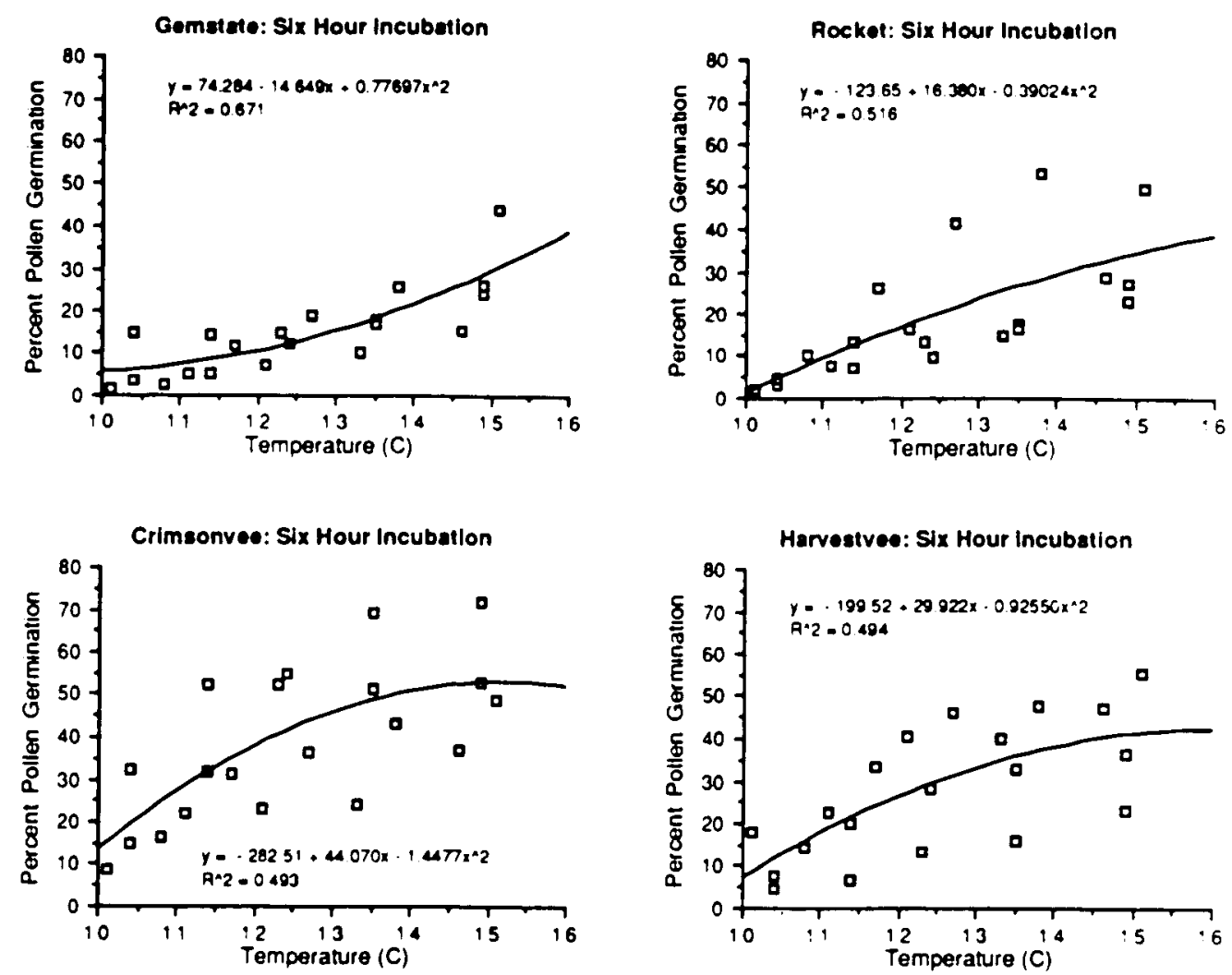

Figure 9. Relationship between temperature and percent pollen germination, after six hours of incubation, for four tomato cultivars. Data from four replicates are included.

53 

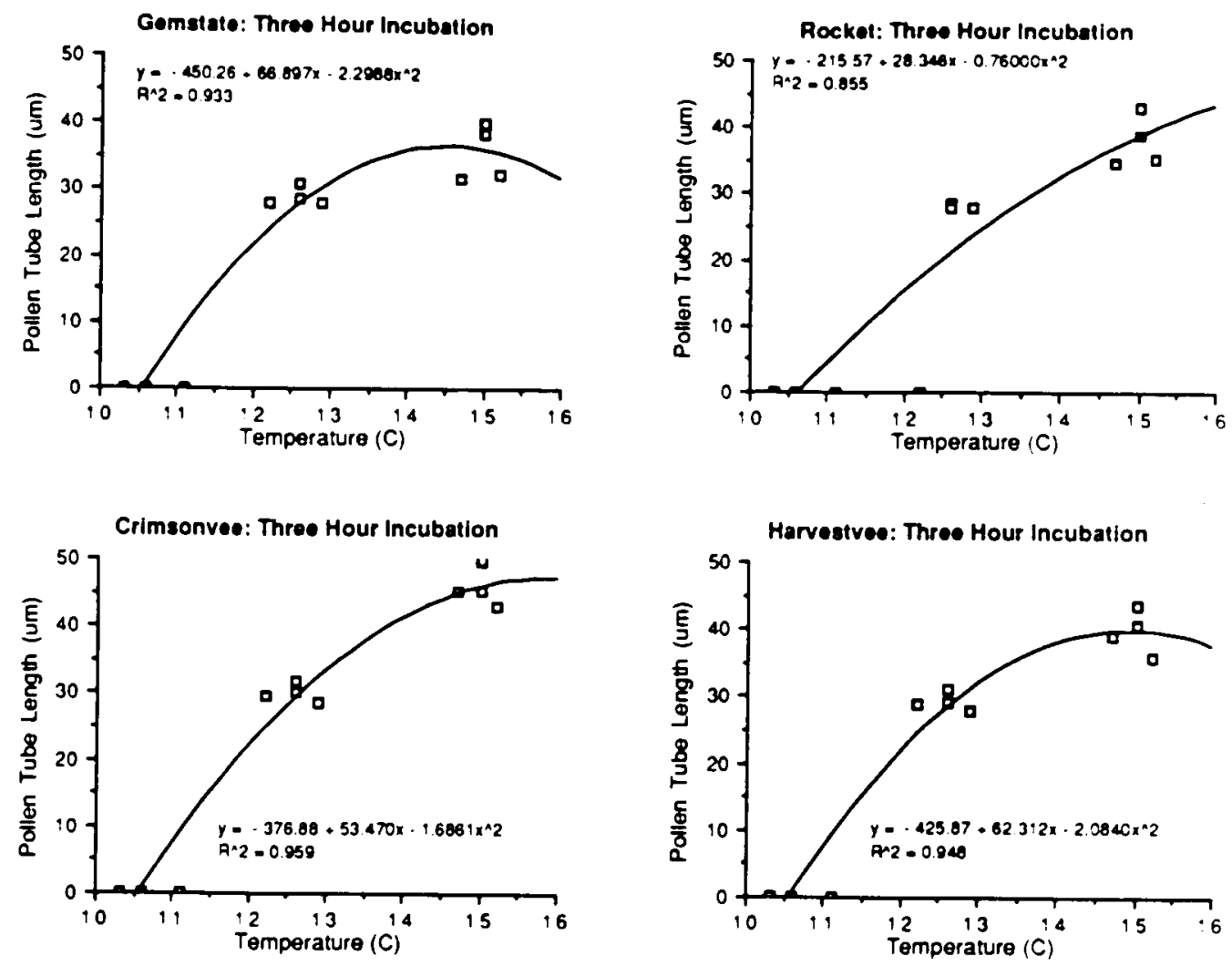

Figure 10. Relationship between temperature and mean pollen tube length, after three hours of incubation, for four tomato cultivars. Data from four replicates are included. 

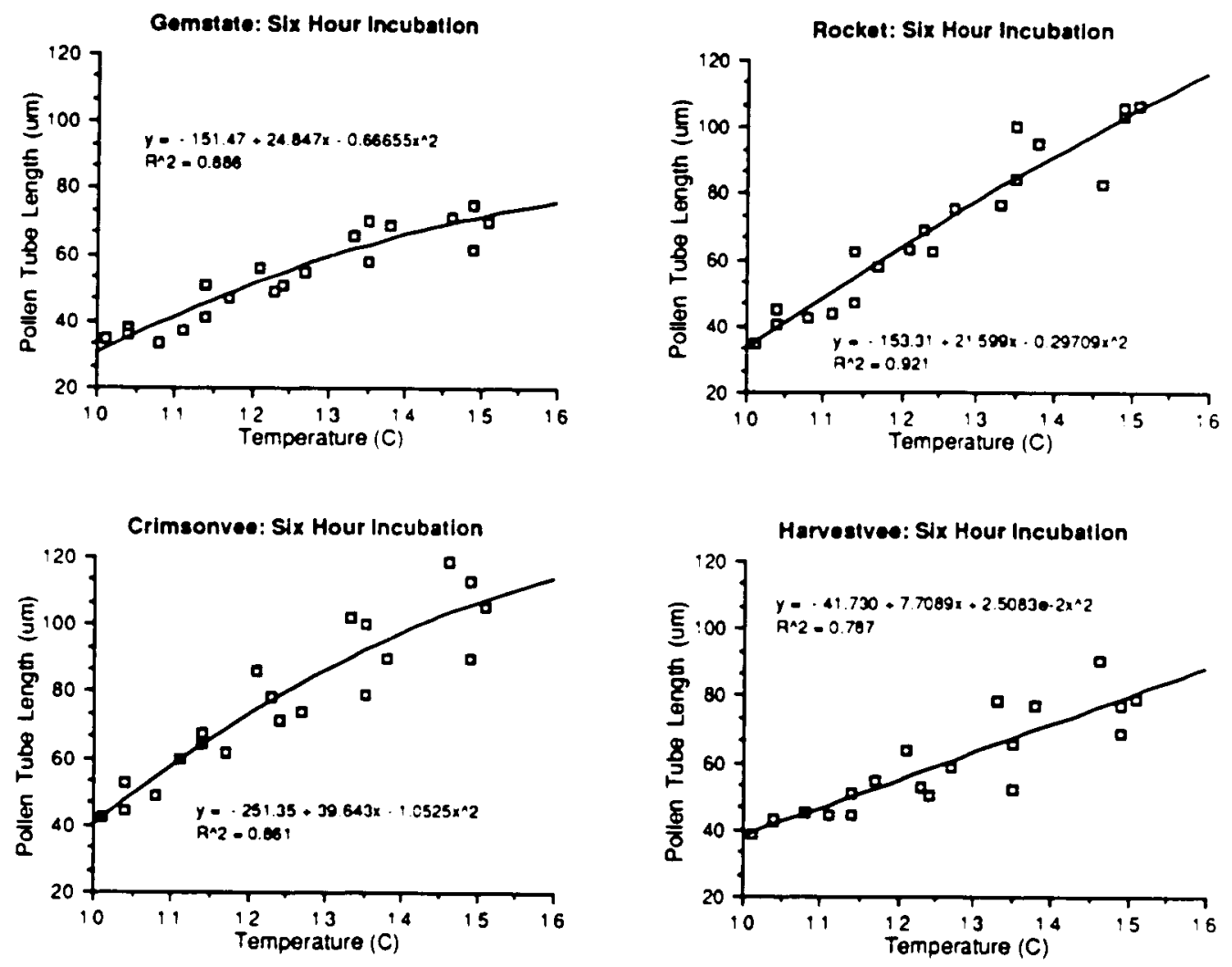

Figure 11. Relationship between temperature and mean pollen tube length, after six hours of incubation, for four tomato cultivars. Data from four replicates are included. 
The relationship between temperature and mean pollen tube length after three or six hours of incubation was described by a negative second degree partial regression coefficient for all cultivars, except for 'Harvestvee' data from the six hour incubation period (0.33946)(Figures 10 , 11). These results are similar to those obtained in Experiment 1 in that mean tube length was directiy related to temperature and in that there was no association between cultivar maturity type and pollen tube growth rate in the low-temperature range tested ( 8 and $15 \mathrm{C}$ for Experiment 1, 10 to $16 \mathrm{C}$ for Experiment 2 ).

The most obvious effect of length of incubation period was a difference in percentage germination. After three hours of incubation at the lowest temperature, there was no germination for any of the cultivars. However, all cultivars germinated when incubation time was extended to six hours incubation (Figures 8,9 ). Thus, given sufficient time, a certain level of in vitro germination can be observed even at suboptimal temperatures (Vasi1, 1987). An experiment designed to investigate pollen germination and pollen tube growth over a wide range of temperature (e.9. 8 to $40 \mathrm{C})$ would provide information pertaining to optimum temperatures for in vitro pollen germination and pollen tube growth. In such an experiment, it is likely that the relationship between temperature and percent pollen germination and between temperature and mean 
pollen tube length would be described by a sigmoidal curve (Dempsey, 1970; Luza ett al.,. 1987; and, Vasil, 1987).

In Vivo Pollen Germination and Pollen Tube Growth of Early and Late Maturing Tomato Cultivars.

Experiment 3.1.

In all instances, the percentage of germinated pollen was higher and pollen tubes grew faster under the normaltemperature regime compared to the low-temperature regime (Figures 12, 13). These results agree with the findings of other workers (Dempsey and Boynton, 1962; Dempsey, 1970; Charles and Harris, 1972). However, percentage germination and rates of tube growth under low temperature conditions were lower and slower, respectively, than those reported by Dempsey (1970), and Charles and Harris (1972).

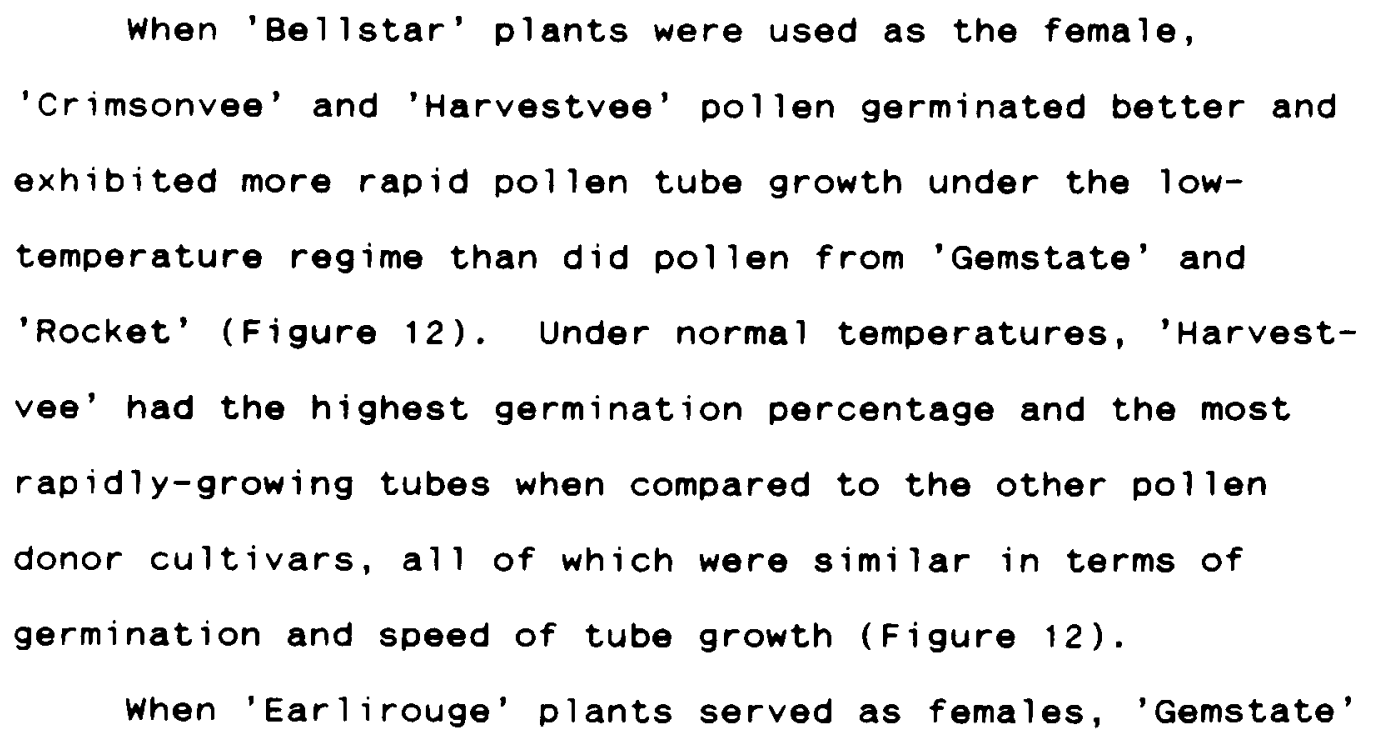




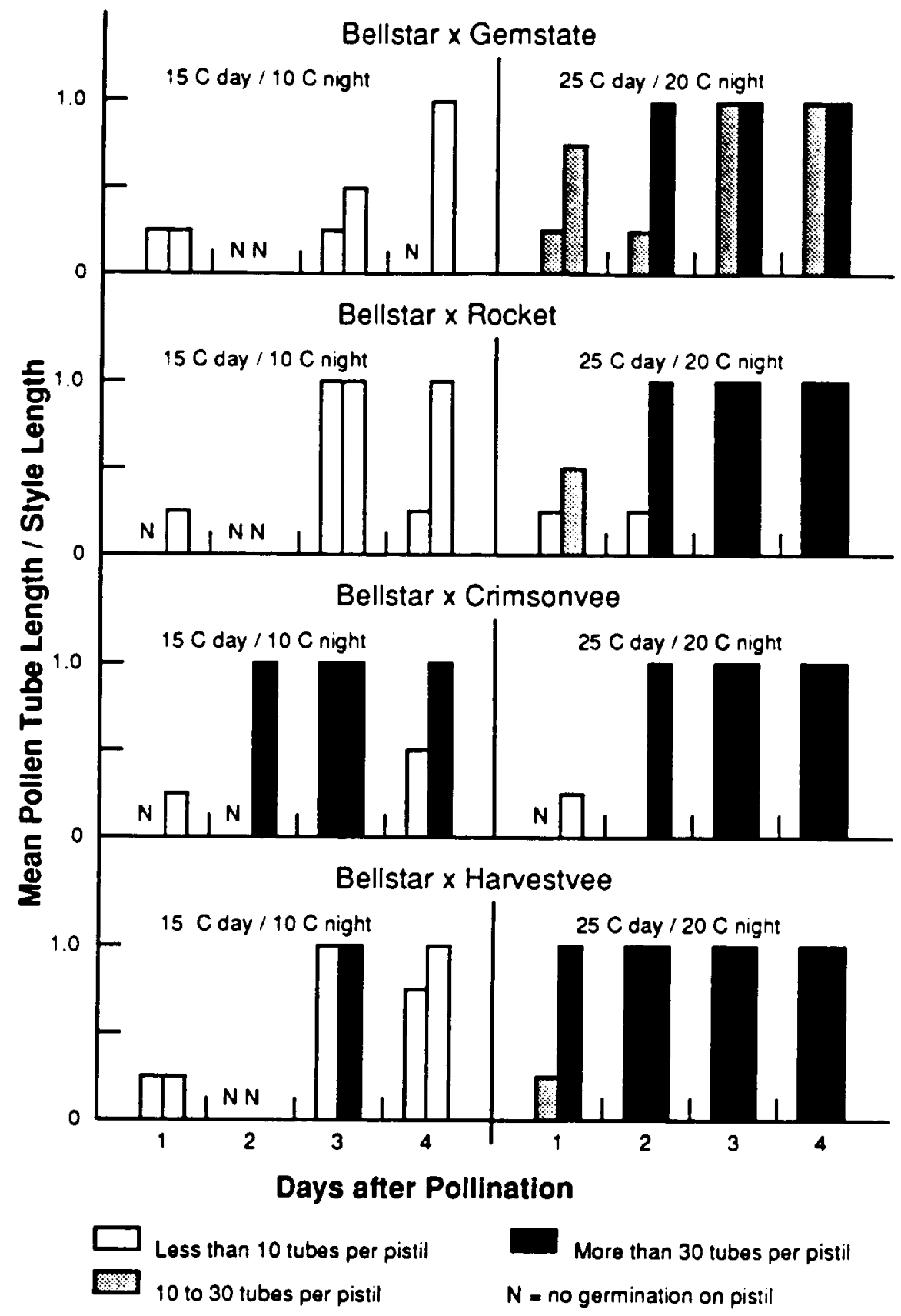

Figure 12. Effect of temperature regime and duration on mean pollen tube length (relative to style length) and pollen tube number for Bellstar pistils pollinated in 1988 by four tomato cultivars. Each bar represents a pistil. 


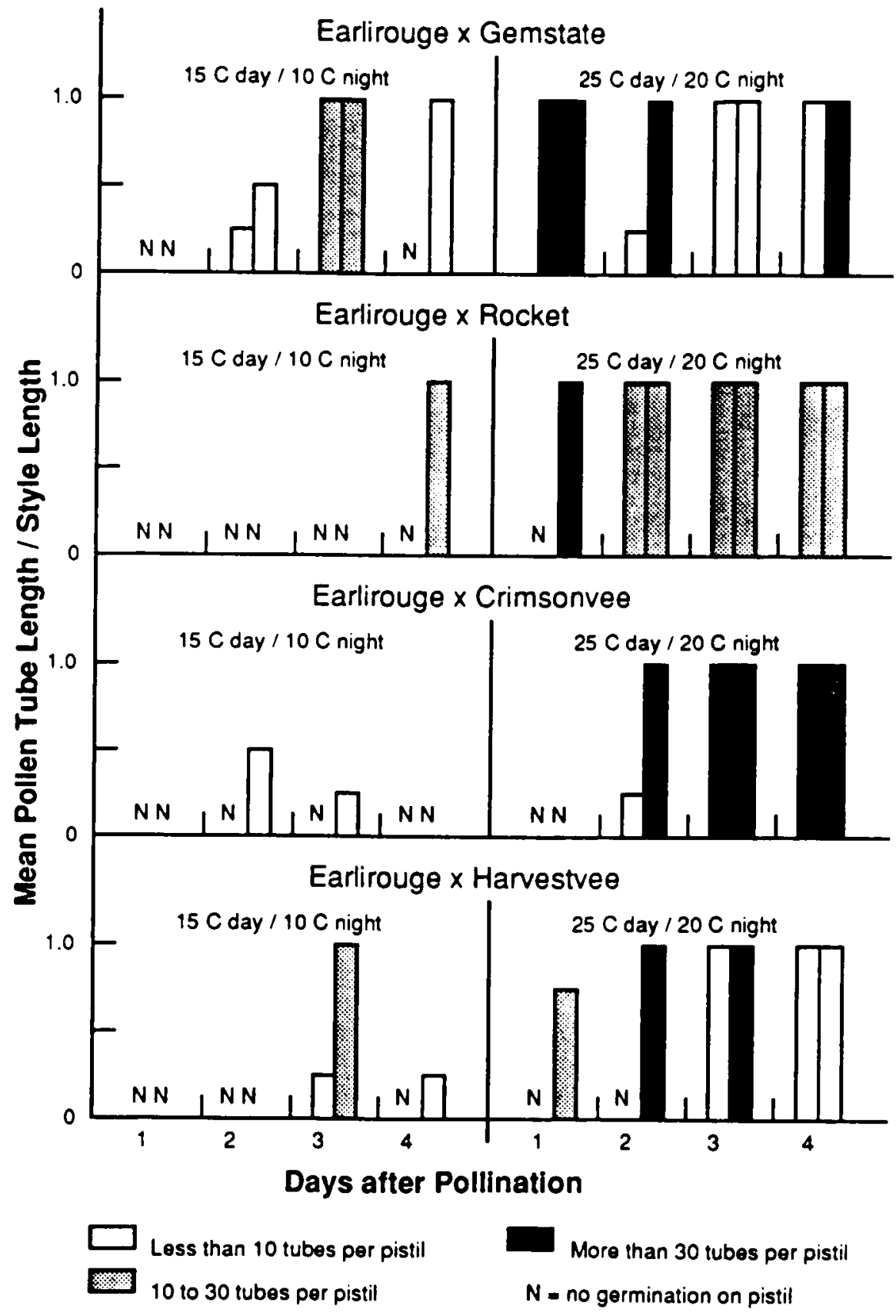

Figure 13. Effect of temperature regime and duration on mean pollen tube length (relative to style length) and pollen tube number for Earlirouge pistils pollinated in 1988 by one of four tomato cultivars. Each bar represents a pistil. 
pollen was superior in germination and showed more rapid pollen tube growth under the low-temperature regime than did the other cultivars, whereas 'Crimsonvee' pollen had the lowest percentage germination and slowest pollen tube growth (Figure 13). Under the normal temperature regime, 'Gemstate' and 'Rocket' pollen tubes grew faster than those of 'Harvestvee' and 'Crimsonvee'. 'Gemstate' and 'Crimsonvee' showed superior pollen germination in comparison to 'Rocket' and 'Harvestvee' under normal temperatures (Figure $13)$.

The results of this experiment suggest no clear relationship between pollen donor maturity type and pollen germination and mean pollen tube growth under different temperature regimes. Although it appeared that pollen from late cultivars had a clear advantage under low temperature conditions when 'Bellstar' was the female, 'Gemstate' pollen was superior to all other cultivars under low temperatures when 'Earlirouge' was the female.

The results of this experiment may have been compromised somewhat by the health of the female plants. These plants were noticeably brittle and were heavily infested with white fly (Trialeurodes vaporariorum Westwood). An interaction between plant condition and low temperature conditions may have resulted in low callose production in pollen tubes and thereby decreased the likelihood of their detection (Martin, 1959) or may have 
impeded dollen germination (Heslop-Harrison, 1987). It is also possible that certain combinations of style and pollen are more important in determining germination percentage and subsequent pollen tube growth than the genotype of the pollen alone.

\section{Experiment 3.2.}

In all instances, pollen germination percentages and pollen tube growth rates at normal temperatures exceeded those at low temperatures (Figures 14, 15). Under low temperatures, levels of pollen germination in this study were higher and rates of pollen tube growth were more rapid than those observed in Experiment 3.1 and were similar to those reported by Charles and Harris (1972).

On 'Bellstar' females, percent pollen germination of 'Harvestvee' and 'Rocket', exposed to low temperatures, was higher and resulting pollen tubes grew faster as compared to pollination with 'Gemstate' and 'Crimsonvee' (Figure 14). Under normal temperatures, all cultivars were similar in both pollen germination percentage and speed of pollen tube growth (Figure 14 ).

When 'Earlirouge' plants served as female, all

cultivars showed similar percentages of pollen germination

under the low-temperature regime, whereas 'Crimsonvee' and

'Harvestree' pollen tubes grew faster than those of

'Gemstate' and 'Rocket' (Figure 15). Under normal- 


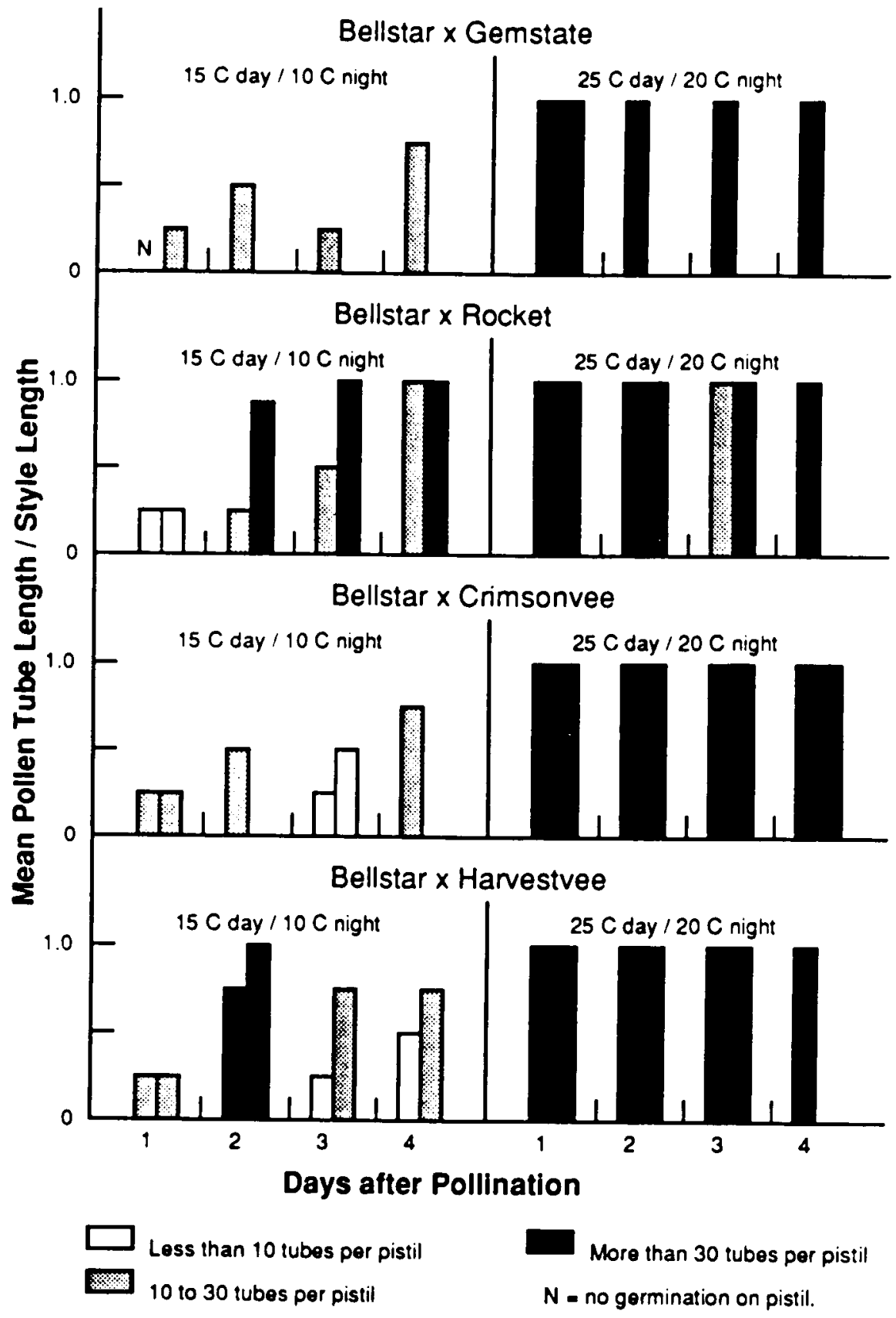

Figure 14. Effect of temperature regime and duration on mean pollen tube length (relative to style length) and pollen tube number for Bellstar pistils pollinated in 1990 by one of four tomato cultivars. Each bar represents one pistil. 


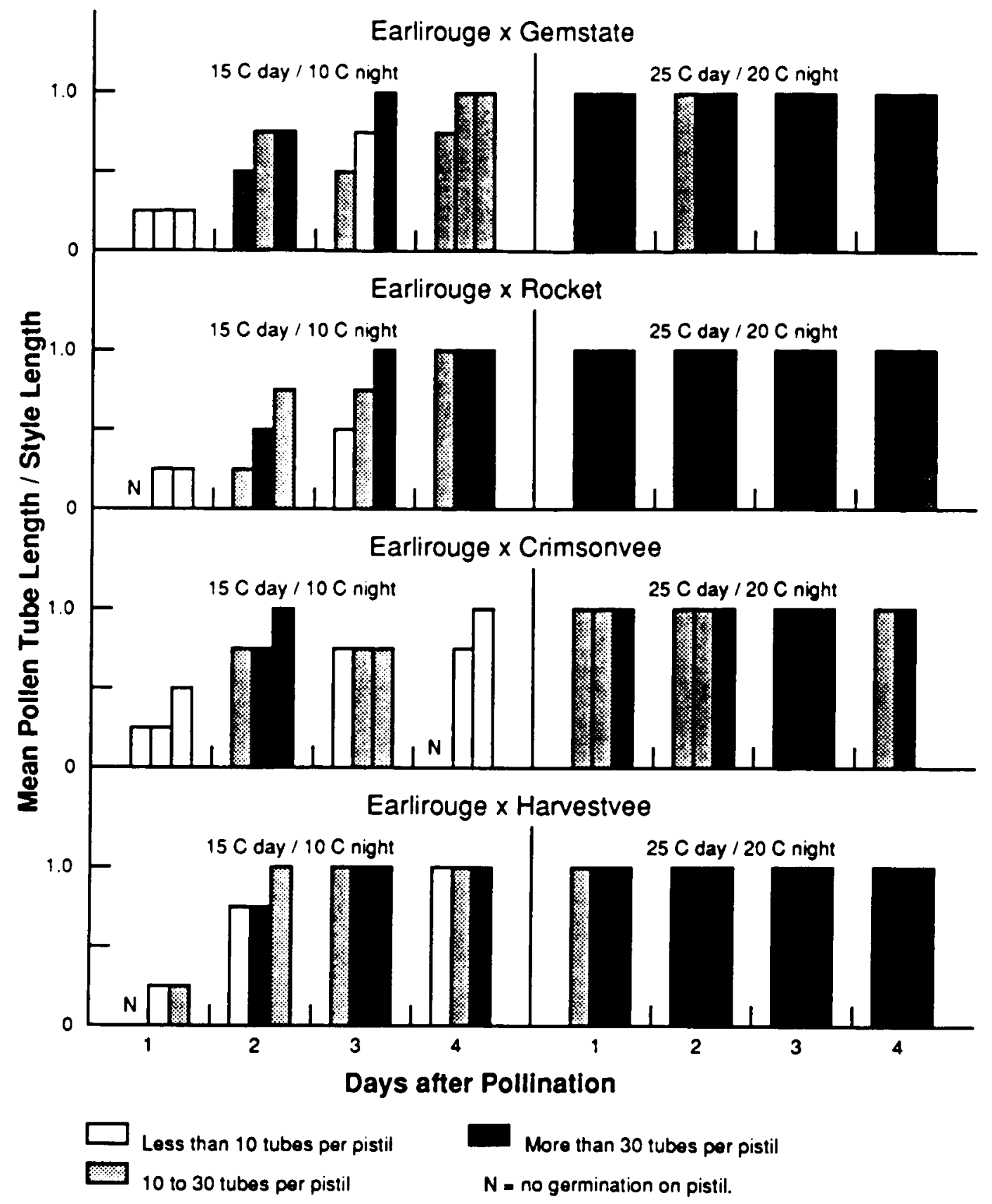

Figure 15. Effect of temperature regime and duration on mean pollen tube length (relative to style length) and pollen tube number for Earlirouge pistils pollinated in 1990 by one of four tomato cultivars. Each bar represents one pistil. 


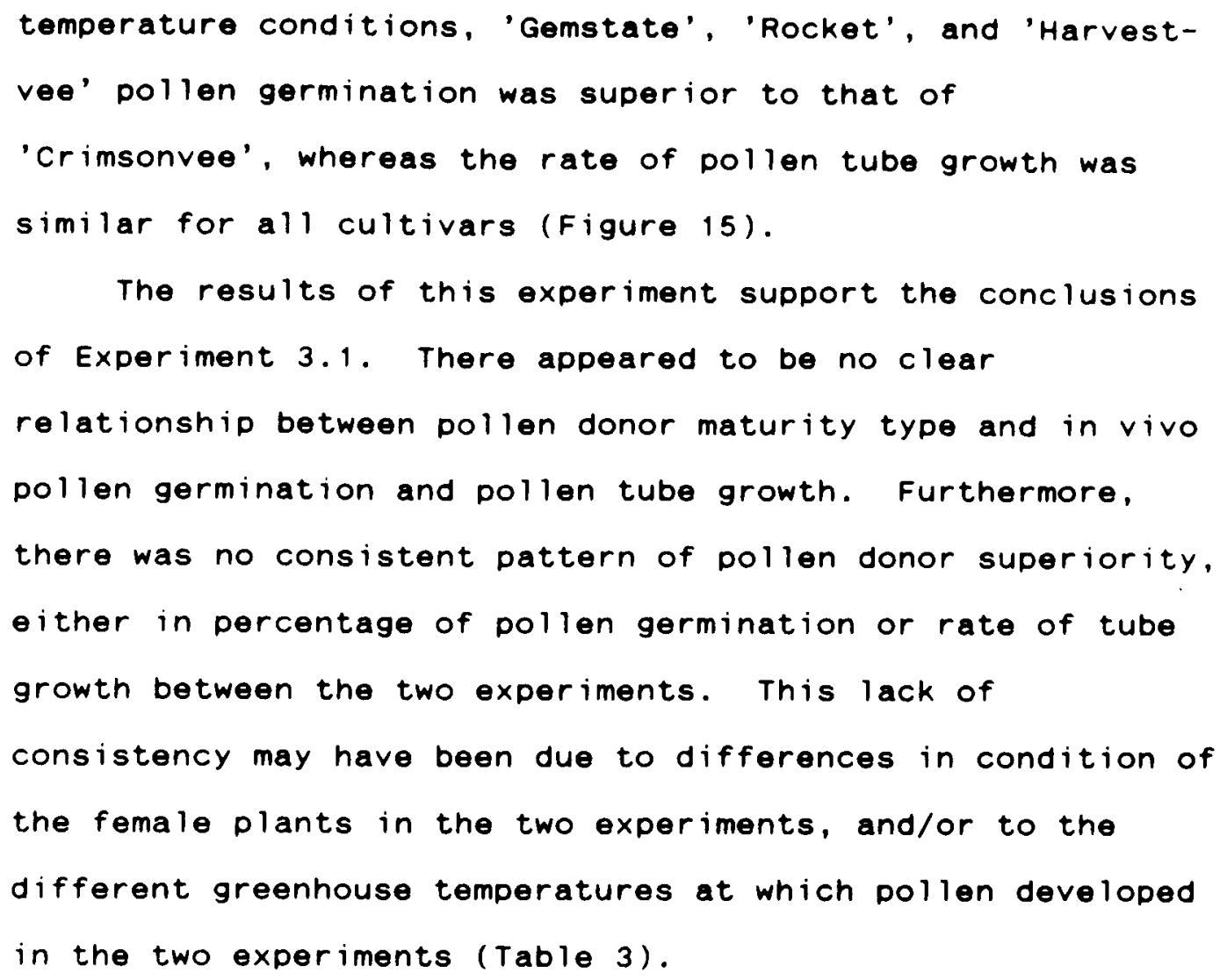

Selective Fertilizations by Pollen Mixtures of Early and

Late Maturing Iomato Cultivars.

\begin{abstract}
Experiment 4.1.
Only three fruits were obtained from pollinations at low temperatures. The most likely reason for the relatively small number of set fruit was that pollen tubes of the early and late cultivars did not grow more than one half the
\end{abstract}




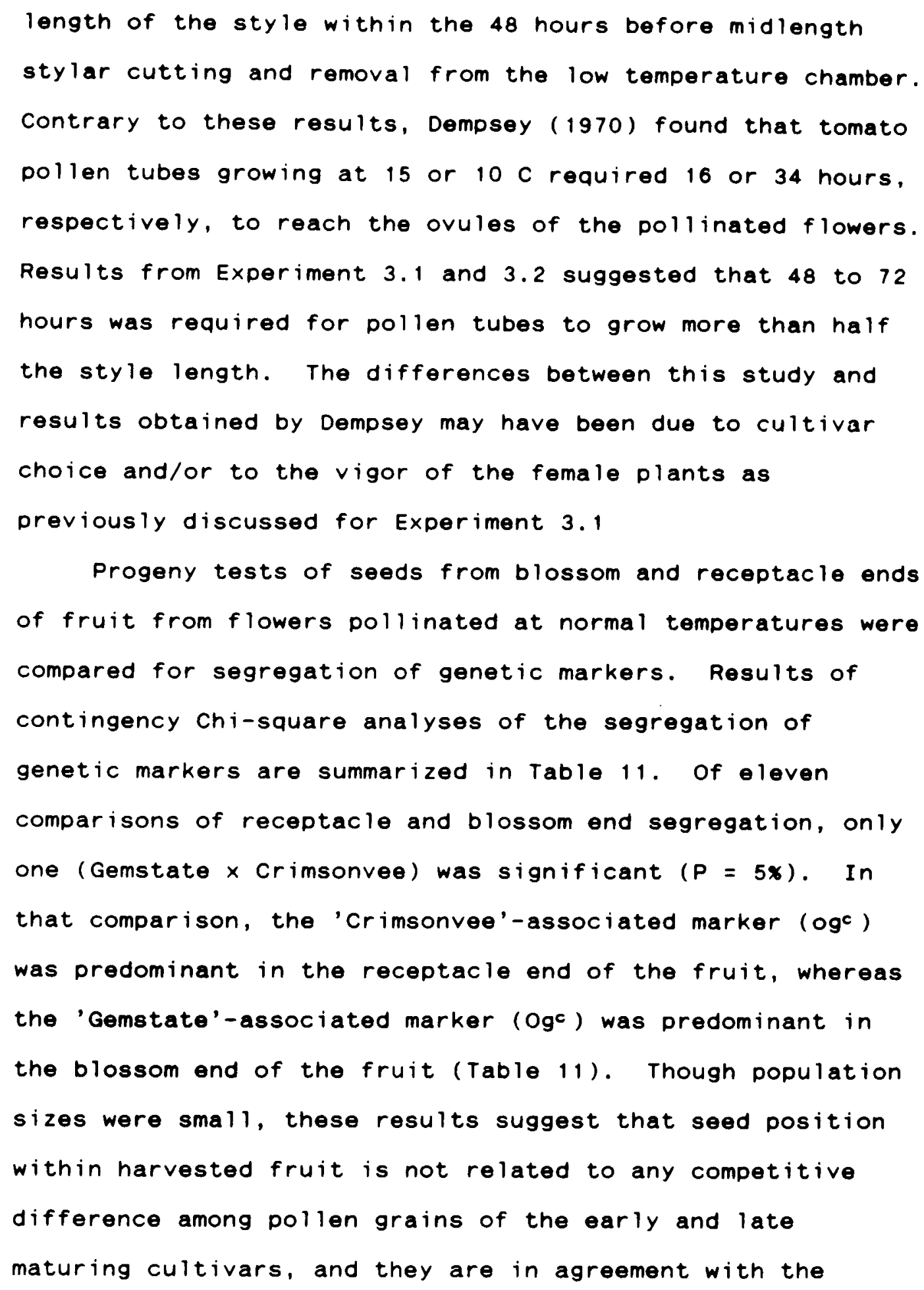


Table 11. Contingency Chi-square analyses of segregation of genetic markers in Experiment 4.1, planted in summer, 1988.

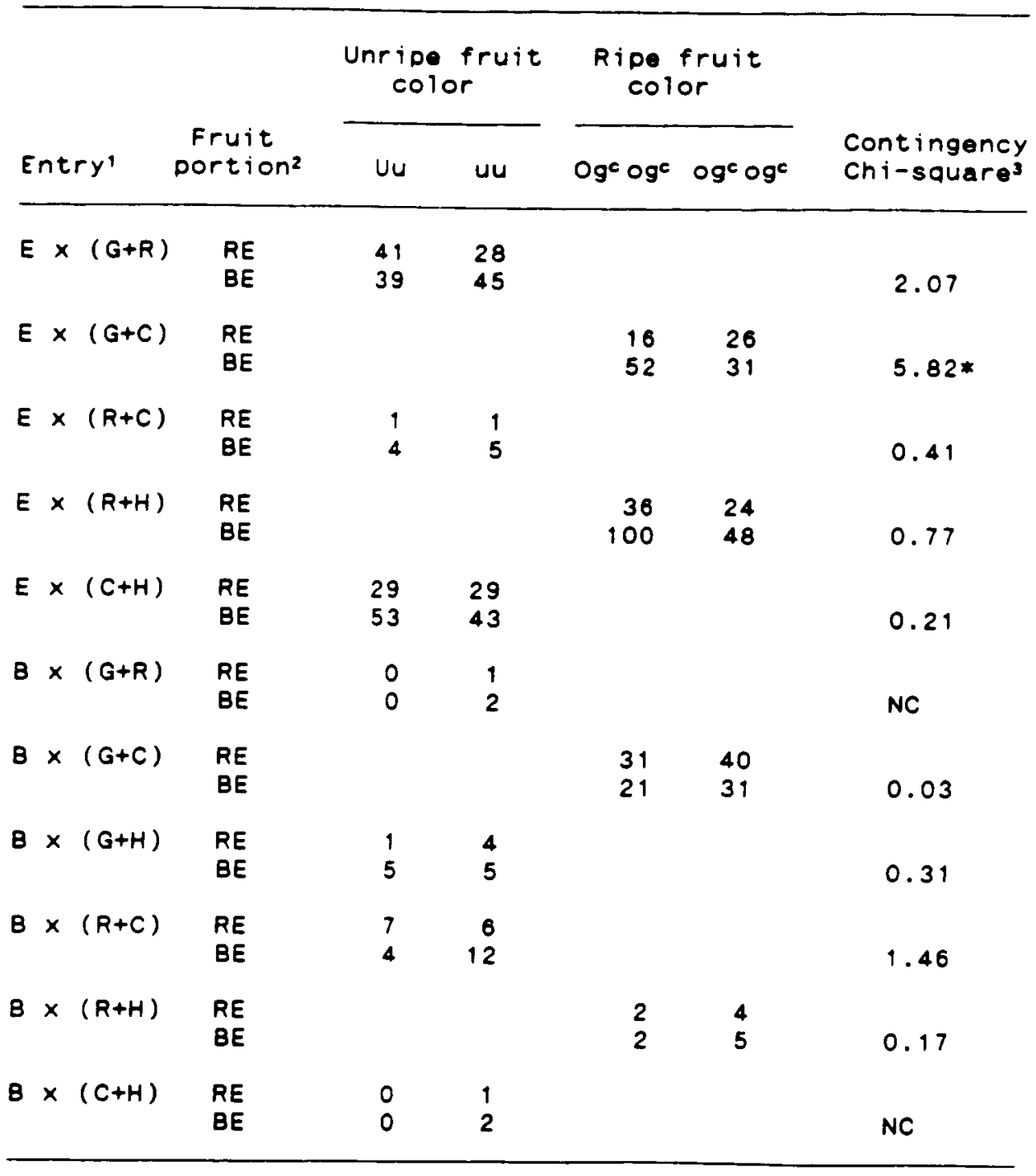

1 Parental cultivars are designated as follows: Gemstate

(G): Rocket (R); Earlirouge (E); Bellstar (B); Crimsonvee

(C); and, Harvestvee (H). E $\times(G+H)$ did not germinate.

2 Fruit portions are designated as follows: receptacle end (RE); blossom end (BE).

3 Significant at the 5x (*) probability level. NC designates that Chi-square could not be calculated.

66 
Table 12. Percent fruit set and mean seed per fruit after pollination treatment in Experiment 4.2.

\begin{tabular}{|c|c|c|c|c|c|c|}
\hline Cross' & $\begin{array}{c}\text { Temper- } \\
\text { ature } \\
\text { (C) }\end{array}$ & $\begin{array}{l}\text { No. } \\
\text { flowers } \\
\text { pollinated }\end{array}$ & $\begin{array}{l}\text { No. } \\
\text { fruit } \\
\text { set }\end{array}$ & $\begin{array}{l}\text { Percent } \\
\text { fruit } \\
\text { set }\end{array}$ & $\begin{array}{l}\text { No. } \\
\text { seeds }\end{array}$ & $\begin{array}{l}\text { Seeds } \\
\text { per } \\
\text { fruit }\end{array}$ \\
\hline$E \underset{.1}{x}(R+H)$ & $\begin{array}{l}25 / 20 \\
15 / 10\end{array}$ & $\begin{array}{l}11 \\
14\end{array}$ & $\begin{array}{l}9 \\
4\end{array}$ & $\begin{array}{l}81.8 \\
28.6\end{array}$ & $\begin{array}{r}870 \\
41\end{array}$ & $\begin{array}{l}96.7 \\
10.3\end{array}$ \\
\hline$E \times(R+C)$ & $\begin{array}{l}25 / 20 \\
15 / 10\end{array}$ & $\begin{array}{l}15 \\
24\end{array}$ & $\begin{array}{l}8 \\
9\end{array}$ & $\begin{array}{l}53.3 \\
37.5\end{array}$ & $\begin{array}{l}386 \\
175\end{array}$ & $\begin{array}{l}48.3 \\
19.4\end{array}$ \\
\hline$B \times(R+C)$ & $\begin{array}{l}25 / 20 \\
15 / 10\end{array}$ & $\begin{array}{l}12 \\
17\end{array}$ & $\begin{array}{l}7 \\
2\end{array}$ & $\begin{array}{l}58.3 \\
11.8\end{array}$ & $\begin{array}{r}133 \\
9\end{array}$ & $\begin{array}{r}19.0 \\
4.5\end{array}$ \\
\hline
\end{tabular}

1 Parental cultivars are designated as follows: Rocket (R); Earlirouge (E); Bellstar (B); Crimsonvee (C); and Harvestvee (H). Fruit set and seed per fruit data were not recorded for the other crosses made in Experiment 4.2 due to blossom end rot.

2 Percent fruit set equals the number of fruit set divided by the number of flowers pollinated multiplied by 100 . 
Table 13. Contingency Chi-square analyses of segregation of genetic markers in Experiment 4.2, planted in summer, 1990.

\begin{tabular}{|c|c|c|c|c|c|c|}
\hline \multirow[b]{2}{*}{ Entry' } & \multirow{2}{*}{$\begin{array}{c}\text { Temper- } \\
\text { ature } \\
\text { (C) }\end{array}$} & \multicolumn{2}{|c|}{$\begin{array}{l}\text { Unripe fruit } \\
\text { color }\end{array}$} & \multicolumn{2}{|c|}{$\begin{array}{l}\text { Ripe fruit } \\
\text { color }\end{array}$} & \multirow{2}{*}{$\begin{array}{l}\text { Contingency } \\
\text { Chi-square }\end{array}$} \\
\hline & & Uu & uu & $\operatorname{Og}^{c} \circ g^{c}$ & $\operatorname{og}^{c} \circ g^{c}$ & \\
\hline$E \times(G+R)$ & $\begin{array}{l}25 / 20 \\
15 / 10\end{array}$ & $\begin{array}{r}11 \\
6\end{array}$ & $\begin{array}{r}25 \\
9\end{array}$ & & & 0.11 \\
\hline$E \times(G+H)$ & $\begin{array}{l}25 / 20 \\
15 / 10\end{array}$ & $\begin{array}{r}10 \\
8\end{array}$ & $\begin{array}{r}11 \\
4\end{array}$ & & & 0.48 \\
\hline$E \times(R+C)$ & $\begin{array}{l}25 / 20 \\
15 / 10\end{array}$ & $\begin{array}{l}15 \\
10\end{array}$ & $\begin{array}{l}19 \\
28\end{array}$ & & & 1.78 \\
\hline$E \times(R+H)$ & $\begin{array}{l}25 / 20 \\
15 / 10\end{array}$ & & & $\begin{array}{l}31 \\
12\end{array}$ & $\begin{array}{l}4 \\
0\end{array}$ & 0.39 \\
\hline$B \times(G+C)$ & $\begin{array}{l}25 / 20 \\
15 / 10\end{array}$ & & & $\begin{array}{r}12 \\
4\end{array}$ & $\begin{array}{r}21 \\
1\end{array}$ & 1.84 \\
\hline$B \times(R+C)$ & $\begin{array}{l}25 / 20 \\
15 / 10\end{array}$ & $\begin{array}{r}11 \\
3\end{array}$ & $\begin{array}{r}27 \\
5\end{array}$ & & & 0.003 \\
\hline
\end{tabular}

1 Parental cultivars are designated as follows: Gemstate (G); Rocket (R); Earlirouge (E); Bellstar (B); Crimsonvee (C); and, Harvestvee (H).

2 Values exceeding a Chi-square of 3.84 are significant at the 5x (") probability level. 
The probable reason for this difference is that the genetic and adaptive dissimilarities between $L$. esculentum and $L$. hirsutum provided more variation for gametophytic selection than did the dissimilarities among early and late cultivars of L. esculentum (Maisonneuve et al., 1986).

Selective Self-Fertilizations of Fl Hybrids of Early and Late Maturing Iomato Cultivars.

\begin{abstract}
Experiment 5.1 .
Percent fruit set and mean number of seeds per fruit following artificial self-pollination are presented in Table 14. In seven of eleven hybrids, percent fruit set was reduced following self-pollination at low temperature in comparison to self-pollination at normal temperature (Table 14). Fewer seeds per fruit were obtained under lowtemperature pollinations in comparison to normal-temperature pollinations in nine of eleven hybrids following selfpollination (Table 14). These results agree with those of Maisonneuve et al. (1986) and appear to be biologically significant. However, pollination temperature did not affect percent fruit set and mean seeds per fruit according to Wilcoxon's signed Rank Test $(P=5 x)$.

Eleven $F_{2}$ populations derived from $F_{1}$ plants selfpollinated at normal temperatures were compared with similar populations derived from low temperature-pollination for
\end{abstract}


Table 14. Percent fruit set and mean seeds per fruit after self-pollination at normal (25 C day / $20 \mathrm{C}$ night) or low (15 C day / $10 \mathrm{C}$ night) temperature in Experiment 5.1 .

\begin{tabular}{|c|c|c|c|c|c|c|c|c|}
\hline & ybr & -idי & $\begin{array}{l}\text { Temper- } \\
\text { ature } \\
\text { (C) }\end{array}$ & $\begin{array}{l}\text { No. } \\
\text { flowers } \\
\text { pollinated }\end{array}$ & $\begin{array}{l}\text { No. } \\
\text { fruit } \\
\text { set }\end{array}$ & $\begin{array}{l}\text { Percent } \\
\text { fruit } \\
\text { set }\end{array}$ & $\begin{array}{l}\text { No. } \\
\text { seeds }\end{array}$ & $\begin{array}{l}\text { Seeds } \\
\text { per } \\
\text { fruit }\end{array}$ \\
\hline G & $\begin{array}{l}x \\
.\end{array}$ & $R$ & $\begin{array}{l}25 / 20 \\
15 / 10\end{array}$ & $\begin{array}{l}11 \\
11\end{array}$ & $\begin{array}{l}8 \\
9\end{array}$ & $\begin{array}{l}72.7 \\
81.8\end{array}$ & $\begin{array}{l}440 \\
393\end{array}$ & $\begin{array}{l}55.0 \\
43.6\end{array}$ \\
\hline $\mathbf{G}$ & $x$ & $C$ & $\begin{array}{l}25 / 20 \\
15 / 10\end{array}$ & $\begin{array}{l}10 \\
14\end{array}$ & $\begin{array}{l}8 \\
1\end{array}$ & $\begin{array}{r}80.0 \\
7.1\end{array}$ & $\begin{array}{r}359 \\
20\end{array}$ & $\begin{array}{l}44.9 \\
20.0\end{array}$ \\
\hline G & $\begin{array}{l}x \\
. "\end{array}$ & $H$ & $\begin{array}{l}25 / 20 \\
15 / 10\end{array}$ & $\begin{array}{l}11 \\
10\end{array}$ & $\begin{array}{l}9 \\
7\end{array}$ & $\begin{array}{l}81.8 \\
70.0\end{array}$ & $\begin{array}{r}420 \\
88\end{array}$ & $\begin{array}{l}46.7 \\
12.6\end{array}$ \\
\hline $\mathbf{R}$ & $\begin{array}{l}x \\
\ddot{n}\end{array}$ & $\mathbf{G}$ & $\begin{array}{l}25 / 20 \\
15 / 10\end{array}$ & $\begin{array}{l}12 \\
13\end{array}$ & $\begin{array}{r}12 \\
8\end{array}$ & $\begin{array}{r}100.0 \\
61.5\end{array}$ & $\begin{array}{l}938 \\
243\end{array}$ & $\begin{array}{l}78.2 \\
30.4\end{array}$ \\
\hline $\mathbf{R}$ & $\begin{array}{l}x \\
. .\end{array}$ & c & $\begin{array}{l}25 / 20 \\
15 / 10\end{array}$ & $\begin{array}{l}27 \\
24\end{array}$ & $\begin{array}{l}18 \\
10\end{array}$ & $\begin{array}{l}66.7 \\
41.7\end{array}$ & $\begin{array}{r}1,104 \\
439\end{array}$ & $\begin{array}{l}61.3 \\
43.9\end{array}$ \\
\hline $\mathrm{R}$ & $\begin{array}{l}x \\
a\end{array}$ & $H$ & $\begin{array}{l}25 / 20 \\
15 / 10\end{array}$ & $\begin{array}{r}12 \\
7\end{array}$ & $\begin{array}{l}3 \\
2\end{array}$ & $\begin{array}{l}25.0 \\
28.6\end{array}$ & $\begin{array}{r}190 \\
86\end{array}$ & $\begin{array}{l}63.3 \\
43.0\end{array}$ \\
\hline C & $\begin{array}{l}x \\
. "\end{array}$ & G & $\begin{array}{l}25 / 20 \\
15 / 10\end{array}$ & $\begin{array}{l}24 \\
22\end{array}$ & $\begin{array}{l}18 \\
13\end{array}$ & $\begin{array}{l}75.0 \\
59.1\end{array}$ & $\begin{array}{r}1,129 \\
692\end{array}$ & $\begin{array}{l}62.7 \\
53.2\end{array}$ \\
\hline C & $\underset{x}{x}$ & $R$ & $\begin{array}{l}25 / 20 \\
15 / 10\end{array}$ & $\begin{array}{l}11 \\
12\end{array}$ & $\begin{array}{l}8 \\
1\end{array}$ & $\begin{array}{r}72.7 \\
8.3\end{array}$ & $\begin{array}{r}423 \\
20\end{array}$ & $\begin{array}{l}52.9 \\
20.0\end{array}$ \\
\hline$C$ & $\times 1$ & $\mathrm{H}$ & $\begin{array}{l}25 / 20 \\
15 / 10\end{array}$ & $\begin{array}{r}8 \\
17\end{array}$ & $\begin{array}{l}0 \\
0\end{array}$ & $\begin{array}{l}0.0 \\
0.0\end{array}$ & $\begin{array}{l}0 \\
0\end{array}$ & $\begin{array}{l}0.0 \\
0.0\end{array}$ \\
\hline$H$ & $\begin{array}{l}x \\
.\end{array}$ & G & $\begin{array}{l}25 / 20 \\
15 / 10\end{array}$ & $\begin{array}{l}16 \\
19\end{array}$ & $\begin{array}{l}9 \\
3\end{array}$ & $\begin{array}{l}56.3 \\
15.8\end{array}$ & $\begin{array}{r}359 \\
26\end{array}$ & $\begin{array}{r}39.9 \\
8.7\end{array}$ \\
\hline$H$ & $\begin{array}{ll}x & F \\
י\end{array}$ & $R$ & $\begin{array}{l}25 / 20 \\
15 / 10\end{array}$ & $\begin{array}{r}7 \\
14\end{array}$ & $\begin{array}{l}4 \\
9\end{array}$ & $\begin{array}{l}57.1 \\
64.3\end{array}$ & $\begin{array}{r}74 \\
200\end{array}$ & $\begin{array}{l}18.5 \\
22.2\end{array}$ \\
\hline$H$ & $\begin{array}{l}x \\
.\end{array}$ & & $\begin{array}{l}25 / 20 \\
15 / 10\end{array}$ & $\begin{array}{l}13 \\
10\end{array}$ & $\begin{array}{l}1 \\
3\end{array}$ & $\begin{array}{r}7.7 \\
30.0\end{array}$ & $\begin{array}{l}10 \\
68\end{array}$ & $\begin{array}{l}10.0 \\
22.7\end{array}$ \\
\hline
\end{tabular}

1 Parental cultivars are designated as follows: Gemstate $(G)$; Rocket (R); Crimsonvee (C); and Harvestvee (H).

2 Percent fruit set equals the number of fruit set divided by the number of flowers pollinated multiplied by 100 . 
days from seeding to first flower and days from seeding to first ripe (Tables 15, 16, 17, 18). Mean number of days from seeding to first flower differed by one or more days for three comparisons $(G \times H, R \times H, H \times G)$ ( Table 15), but in only one of these three comparisons $(R \times H)$ was the difference statistically significant ( $t$-test, $P=5 x)$. In this comparison, the mean number of days to first flower of the population derived from low-temperature self-pollination was 1.5 days less (earlier) than that of the population derived from the normal-temperature treatment (Table 15). When the frequency distributions of days from seeding to first flower of $F_{2}$ populations derived from normaltemperature self-pollination were compared to those from similar genetic populations derived from low-temperature self-pollinations, the differences in two of eleven comparisons $(R \times H, H \times G)$ were significant at the $1 \%$ level (Table 16). Significance in one of these two comparisons (H $x G)$ was most likely due to the widely different sizes of the $F_{2}$ populations compared (Table 15) and to the limitations of the contingency Chi-square in handing such wide differences (Steel and Torrie, 1980). The mean number of days from seeding to first ripe differed by one or more for five comparisons ( $G \times C, G \times H, R \times H, H \times G, H \times C)$ (Table 17). In four of these comparisons $(G \times H, R \times H, H \times$ $G, H \times C)$, the differences were statistically significant $(t$-test, $P=5 x)$. In one of these four comparisons $(R \times H)$, 
Table 15. Summary of days from seeding to first flower from Experiments $5.1,5.2$, and 5.3 .

\begin{tabular}{|c|c|c|c|c|c|c|c|c|c|c|c|c|}
\hline \multirow{3}{*}{\multicolumn{3}{|c|}{ Entry' }} & \multirow{3}{*}{$\begin{array}{c}\text { Temper- } \\
\text { ature } \\
\text { (C) }\end{array}$} & \multicolumn{2}{|c|}{ Days } & \multirow{2}{*}{ from } & \multicolumn{2}{|c|}{ seeding to } & \multirow{2}{*}{ first } & \multicolumn{3}{|l|}{ flower } \\
\hline & & & & \multicolumn{2}{|c|}{ EXP. 5.1} & & \multicolumn{2}{|c|}{ Exp. 5.2} & & \multicolumn{3}{|c|}{ Exp. 5.3} \\
\hline & & & & Mean & SE & $n$ & Mean & SE & $n$ & Mean & SE & $n$ \\
\hline G & $x$ & $\mathbf{R}$ & $\begin{array}{l}25 / 20 \\
15 / 10\end{array}$ & $\begin{array}{l}46.3 \\
46.3\end{array}$ & $\begin{array}{l}0.4 \\
0.3\end{array}$ & $\begin{array}{l}79 \\
72\end{array}$ & \multicolumn{3}{|c|}{----} & $\begin{array}{l}42.7 \\
41.7\end{array}$ & $\begin{array}{l}0.4 \\
0.4\end{array}$ & $\begin{array}{l}67 \\
73\end{array}$ \\
\hline G & $\begin{array}{l}x \\
\ddot{*}\end{array}$ & C & $\begin{array}{l}25 / 20 \\
15 / 10\end{array}$ & $\begin{array}{l}48.7 \\
48.8\end{array}$ & $\begin{array}{l}0.3 \\
0.5\end{array}$ & $\begin{array}{l}80 \\
16\end{array}$ & $\begin{array}{l}43.3 \\
43.9\end{array}$ & $\begin{array}{l}0.5 \\
0.5\end{array}$ & $\begin{array}{l}29 \\
52\end{array}$ & $\begin{array}{l}43.3 \\
43.0\end{array}$ & $\begin{array}{l}0.4 \\
0.4\end{array}$ & $\begin{array}{l}71 \\
65\end{array}$ \\
\hline G & $\begin{array}{l}x \\
\ddot{\prime}\end{array}$ & H & $\begin{array}{l}25 / 20 \\
15 / 10\end{array}$ & $\begin{array}{l}49.1 \\
50.4\end{array}$ & $\begin{array}{l}0.4 \\
0.5\end{array}$ & $\begin{array}{l}49 \\
41\end{array}$ & $\begin{array}{l}45.3 \\
46.0\end{array}$ & $\begin{array}{l}0.3 \\
0.6\end{array}$ & $\begin{array}{l}78 \\
31\end{array}$ & $\begin{array}{l}45.1 \\
44.0\end{array}$ & $\begin{array}{l}0.4 \\
0.3\end{array}$ & $\begin{array}{l}74 \\
80\end{array}$ \\
\hline $\mathbf{R}$ & $x$ & G & $\begin{array}{l}25 / 20 \\
15 / 10\end{array}$ & $\begin{array}{l}47.9 \\
48.1\end{array}$ & $\begin{array}{l}0.3 \\
0.6\end{array}$ & $\begin{array}{l}80 \\
48\end{array}$ & $\begin{array}{l}42.3 \\
43.1\end{array}$ & $\begin{array}{l}1.3 \\
0.4\end{array}$ & $\begin{array}{r}7 \\
74\end{array}$ & $\begin{array}{l}43.7 \\
42.0\end{array}$ & $\begin{array}{l}0.5 \\
0.4\end{array}$ & $\begin{array}{l}68 \\
65\end{array}$ \\
\hline $\mathbf{R}$ & $\stackrel{x}{*}$ & C & $\begin{array}{l}25 / 20 \\
15 / 10\end{array}$ & $\begin{array}{l}47.3 \\
47.8\end{array}$ & $\begin{array}{l}0.3 \\
0.3\end{array}$ & $\begin{array}{l}78 \\
78\end{array}$ & $\begin{array}{l}45.5 \\
44.0\end{array}$ & $\begin{array}{l}0.3 \\
0.3\end{array}$ & $\begin{array}{l}73 \\
65\end{array}$ & $\begin{array}{l}45.0 \\
45.7\end{array}$ & $\begin{array}{l}0.4 \\
0.4\end{array}$ & $\begin{array}{l}74 \\
77\end{array}$ \\
\hline $\mathbf{R}$ & $\begin{array}{l}x \\
"\end{array}$ & $H$ & $\begin{array}{l}25 / 20 \\
15 / 10\end{array}$ & $\begin{array}{l}48.3 \\
46.8\end{array}$ & $\begin{array}{l}0.3 \\
0.2\end{array}$ & $\begin{array}{l}80 \\
79\end{array}$ & $\begin{array}{l}46.4 \\
45.9\end{array}$ & $\begin{array}{l}0.3 \\
0.3\end{array}$ & $\begin{array}{l}78 \\
80\end{array}$ & $\begin{array}{l}44.5 \\
45.6\end{array}$ & $\begin{array}{l}0.4 \\
0.4\end{array}$ & $\begin{array}{l}79 \\
72\end{array}$ \\
\hline C & $x$ & $\mathbf{G}$ & $\begin{array}{l}25 / 20 \\
15 / 10\end{array}$ & $\begin{array}{l}47.4 \\
47.4\end{array}$ & $\begin{array}{l}0.3 \\
0.3\end{array}$ & $\begin{array}{l}77 \\
78\end{array}$ & 42.8 & 0.8 & 13 & $\begin{array}{l}43.4 \\
45.8\end{array}$ & $\begin{array}{l}0.4 \\
0.4\end{array}$ & $\begin{array}{l}73 \\
63\end{array}$ \\
\hline$c$ & $\begin{array}{l}x \\
" \prime\end{array}$ & $\mathbf{R}$ & $\begin{array}{l}25 / 20 \\
15 / 10\end{array}$ & $\begin{array}{l}47.5 \\
47.9\end{array}$ & $\begin{array}{l}0.3 \\
0.4\end{array}$ & $\begin{array}{l}80 \\
16\end{array}$ & $\begin{array}{l}43.6 \\
44.5\end{array}$ & $\begin{array}{l}0.3 \\
0.4\end{array}$ & $\begin{array}{l}79 \\
76\end{array}$ & $\begin{array}{l}43.7 \\
43.7\end{array}$ & $\begin{array}{l}0.3 \\
0.4\end{array}$ & $\begin{array}{l}76 \\
68\end{array}$ \\
\hline H & $\stackrel{x}{*}$ & G & $\begin{array}{l}25 / 20 \\
15 / 10\end{array}$ & $\begin{array}{l}48 \cdot 2 \\
50 \cdot 3\end{array}$ & $\begin{array}{l}0.3 \\
0.9\end{array}$ & $\begin{array}{l}77 \\
13\end{array}$ & $\begin{array}{l}43.9 \\
44.5\end{array}$ & $\begin{array}{l}0.4 \\
0.3\end{array}$ & $\begin{array}{l}80 \\
80\end{array}$ & --- & --- & \\
\hline H & $\begin{array}{l}x \\
*\end{array}$ & $\mathbf{R}$ & $\begin{array}{l}25 / 20 \\
15 / 10\end{array}$ & $\begin{array}{l}48.6 \\
48.3\end{array}$ & $\begin{array}{l}0.3 \\
0.3\end{array}$ & $\begin{array}{l}53 \\
74\end{array}$ & $\begin{array}{l}46.2 \\
46.9\end{array}$ & $\begin{array}{l}0.3 \\
0.3\end{array}$ & $\begin{array}{l}80 \\
70\end{array}$ & $\begin{array}{l}44.9 \\
45.8\end{array}$ & $\begin{array}{l}0.3 \\
0.6\end{array}$ & $\begin{array}{l}69 \\
26\end{array}$ \\
\hline$H$ & $\stackrel{x}{*}$ & C & $\begin{array}{l}25 / 20 \\
15 / 10\end{array}$ & $\begin{array}{l}50.5 \\
49.8\end{array}$ & $\begin{array}{l}0.8 \\
0.3\end{array}$ & $\begin{array}{l}11 \\
58\end{array}$ & & -- & & $\begin{array}{l}49.1 \\
50.3\end{array}$ & $\begin{array}{l}0.4 \\
1.3\end{array}$ & $\begin{array}{r}68 \\
7\end{array}$ \\
\hline $\begin{array}{l}G \\
R \\
C \\
H\end{array}$ & & & $\begin{array}{l}--- \\
--- \\
--- \\
---\end{array}$ & $\begin{array}{l}47.6 \\
44.8 \\
50.3 \\
52.5\end{array}$ & $\begin{array}{l}0.5 \\
0.3 \\
0.2 \\
0.3\end{array}$ & $\begin{array}{l}36 \\
40 \\
40 \\
40\end{array}$ & $\begin{array}{l}42.7 \\
41.7 \\
46.9 \\
49.9\end{array}$ & $\begin{array}{l}1.1 \\
0.4 \\
0.3 \\
0.4\end{array}$ & $\begin{array}{l}15 \\
17 \\
18 \\
17\end{array}$ & $\begin{array}{l}43.1 \\
42.8 \\
46.8 \\
48.5\end{array}$ & $\begin{array}{l}0.9 \\
0.7 \\
0.4 \\
1.0\end{array}$ & $\begin{array}{l}17 \\
16 \\
18 \\
20\end{array}$ \\
\hline
\end{tabular}

- Parental cultivars designated as follows: Gemstate (G): Rocket (R); Crimsonvee (C): Harvestvee (H). 
Table 16. Contingency Chi-square analyses of Experiments $5.1,5.2$, and 5.3. The tests compare frequency distributions of days from seeding to first flower of progeny derived from normal and low temperature selfpollinations of $F_{1}$ hybrids.'

\section{Experiment²}

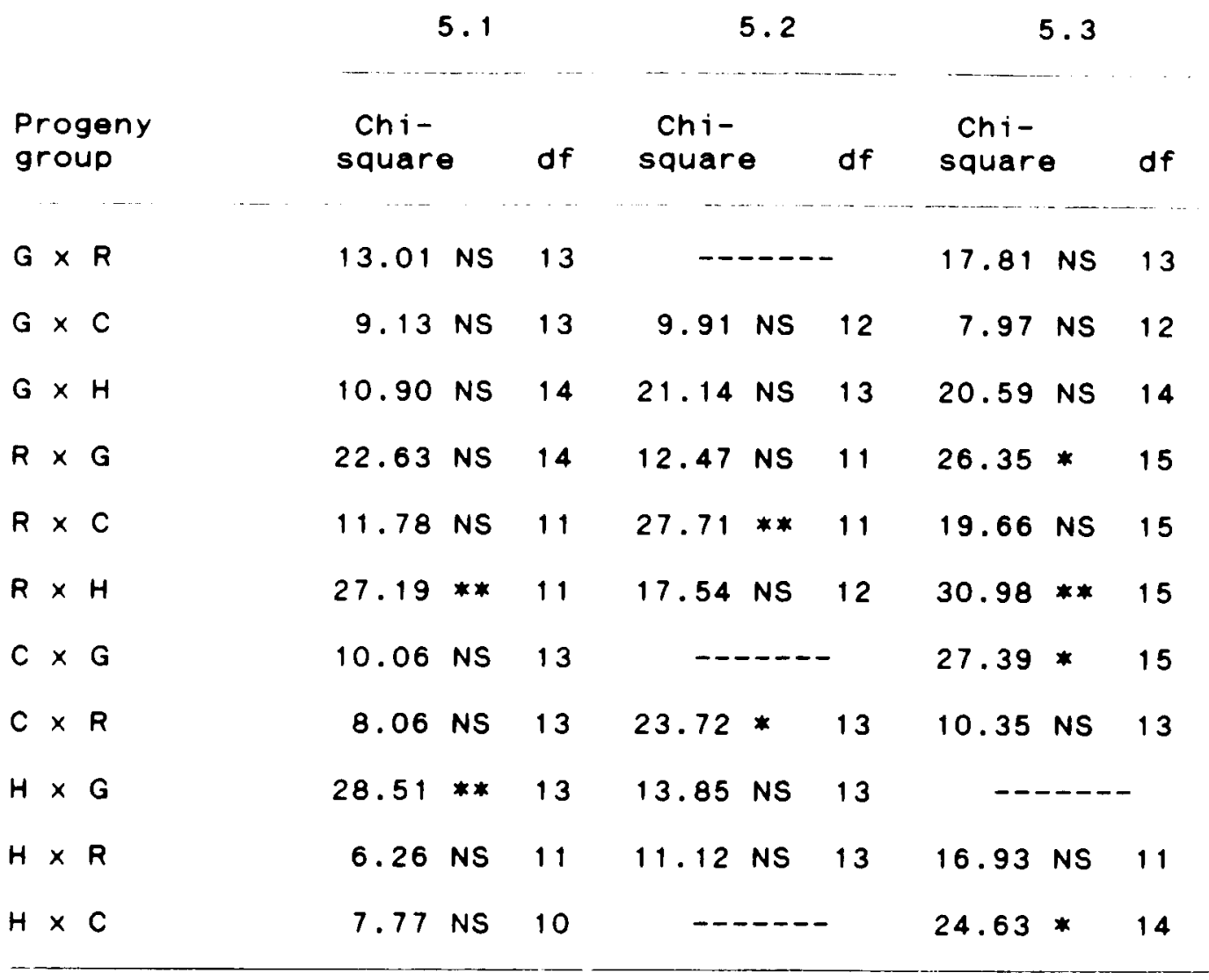

1 Normal and low temperature regimes were $25 \mathrm{C}$ day and $20 \mathrm{C}$ night, and, $15 \mathrm{C}$ day and $10 \mathrm{C}$ night, respectively.

2 Chi-square value significant at the $5 \%(*)$, or $1 *$ (**) probability level, or not significant (NS). 
Table 17. Summary of days from seeding to first ripe fruit from Experiments $5.1,5.2$, and 5.3 .

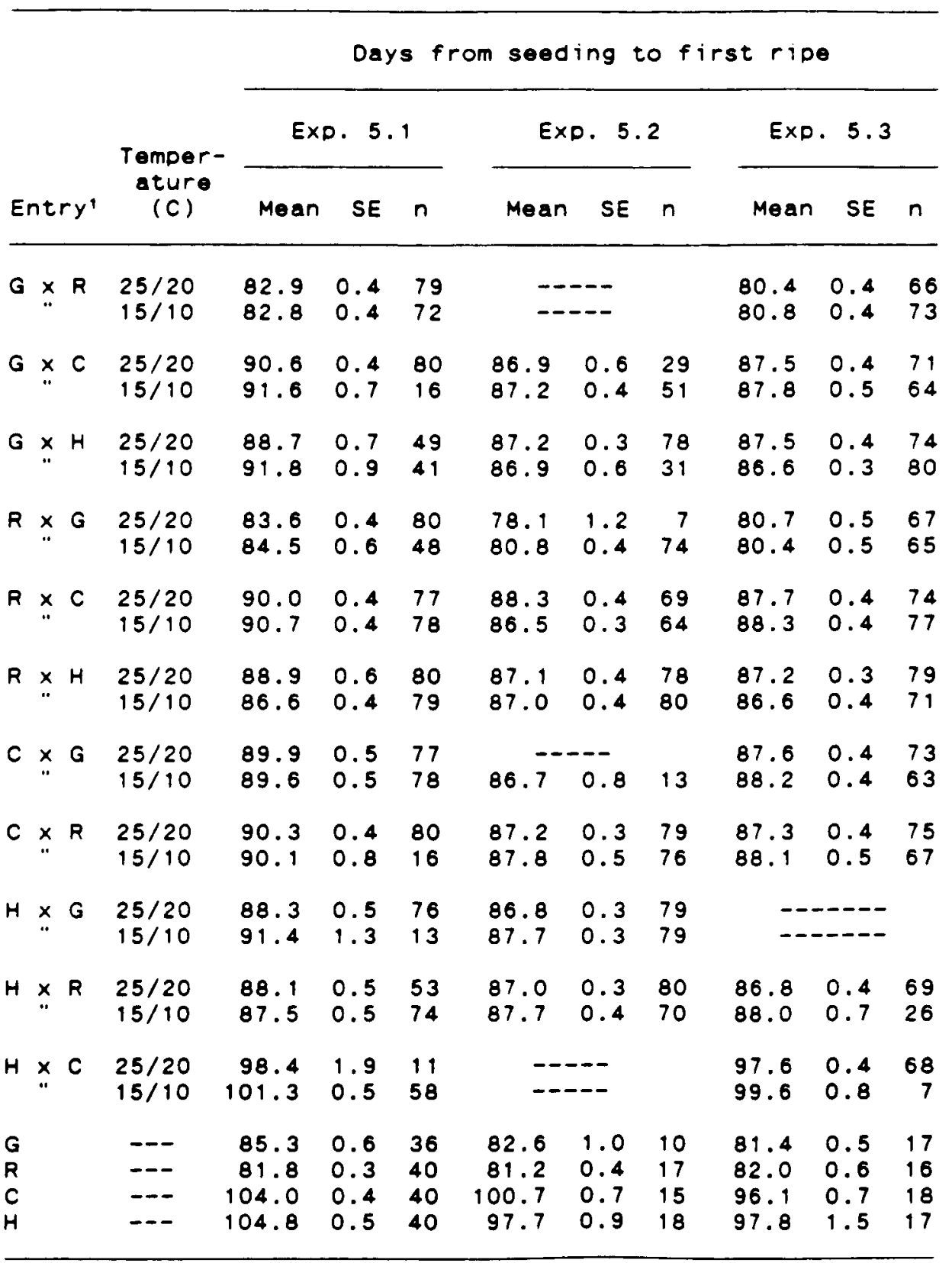

- Parental cultivars designated as follows: Gemstate (G); Rocket (R); Crimsonvee (C): Harvestvee (H). 
Table 18. Contingency Chi-square analyses of Experiments $5.1,5.2$, and 5.3. The tests compare frequency distributions of days from seeding to first ripe fruit of progeny derived from normal and low temperature selfpollinations of $F_{1}$ hybrids.1

Experiment²

\begin{tabular}{|c|c|c|c|c|c|c|c|c|c|c|c|}
\hline \multirow{2}{*}{\multicolumn{3}{|c|}{$\begin{array}{l}\text { Progeny } \\
\text { group }\end{array}$}} & \multicolumn{3}{|c|}{5.1} & \multicolumn{3}{|c|}{5.2} & \multicolumn{3}{|c|}{5.3} \\
\hline & & & $\begin{array}{l}\text { Chi- } \\
\text { square }\end{array}$ & & $d f$ & $\begin{array}{l}\text { Chi- } \\
\text { square }\end{array}$ & & $d f$ & $\begin{array}{l}\text { Chi- } \\
\text { square }\end{array}$ & & $d f$ \\
\hline G & $x$ & $\mathbf{R}$ & 17.82 & NS & 15 & \multicolumn{3}{|c|}{$---\cdots$} & 17.05 & NS & 16 \\
\hline G & $x$ & C & 27.80 & $*$ & 16 & 10.55 & NS & 13 & 18.39 & NS & 18 \\
\hline G & $x$ & $\mathrm{H}$ & 18.56 & NS & 21 & 12.78 & NS & 14 & 16.76 & NS & 16 \\
\hline $\mathbf{R}$ & $x$ & G & 18.22 & NS & 15 & 15.05 & NS & 14 & 17.31 & NS & 17 \\
\hline $\mathbf{R}$ & $x$ & C & 14.43 & NS & 16 & 19.04 & NS & 13 & 20.23 & NS & 16 \\
\hline $\mathbf{R}$ & $x$ & $\mathrm{H}$ & 31.99 & * & 19 & 15.83 & a!s & 15 & 22.73 & NS & 15 \\
\hline C & $x$ & G & 17.01 & NS & 19 & \multicolumn{3}{|c|}{------} & 13.37 & NS & 17 \\
\hline C & $x$ & $\mathbf{R}$ & 24.15 & NS & 16 & 17.03 & NS & 18 & 9.86 & NS & 17 \\
\hline H & $x$ & $\mathbf{G}$ & 32.19 & * & 17 & 18.31 & NS & 13 & \multicolumn{3}{|c|}{-----} \\
\hline H & $x$ & $\mathbf{R}$ & 15.92 & NS & 16 & 25.58 & NS & 16 & 23.99 & NS & 16 \\
\hline H & $x$ & C & 24.20 & * & 14 & \multicolumn{3}{|c|}{$-\cdots-\cdots$} & 14.76 & * & 15 \\
\hline
\end{tabular}

1 Normal and low temperature regimes were $25 \mathrm{C}$ day and $20 \mathrm{C}$ night, and, $15 \mathrm{C}$ day and $10 \mathrm{C}$ night, respectively.

2 Chi-square value significant at the 5* (*) probability level, or not significant (NS). 


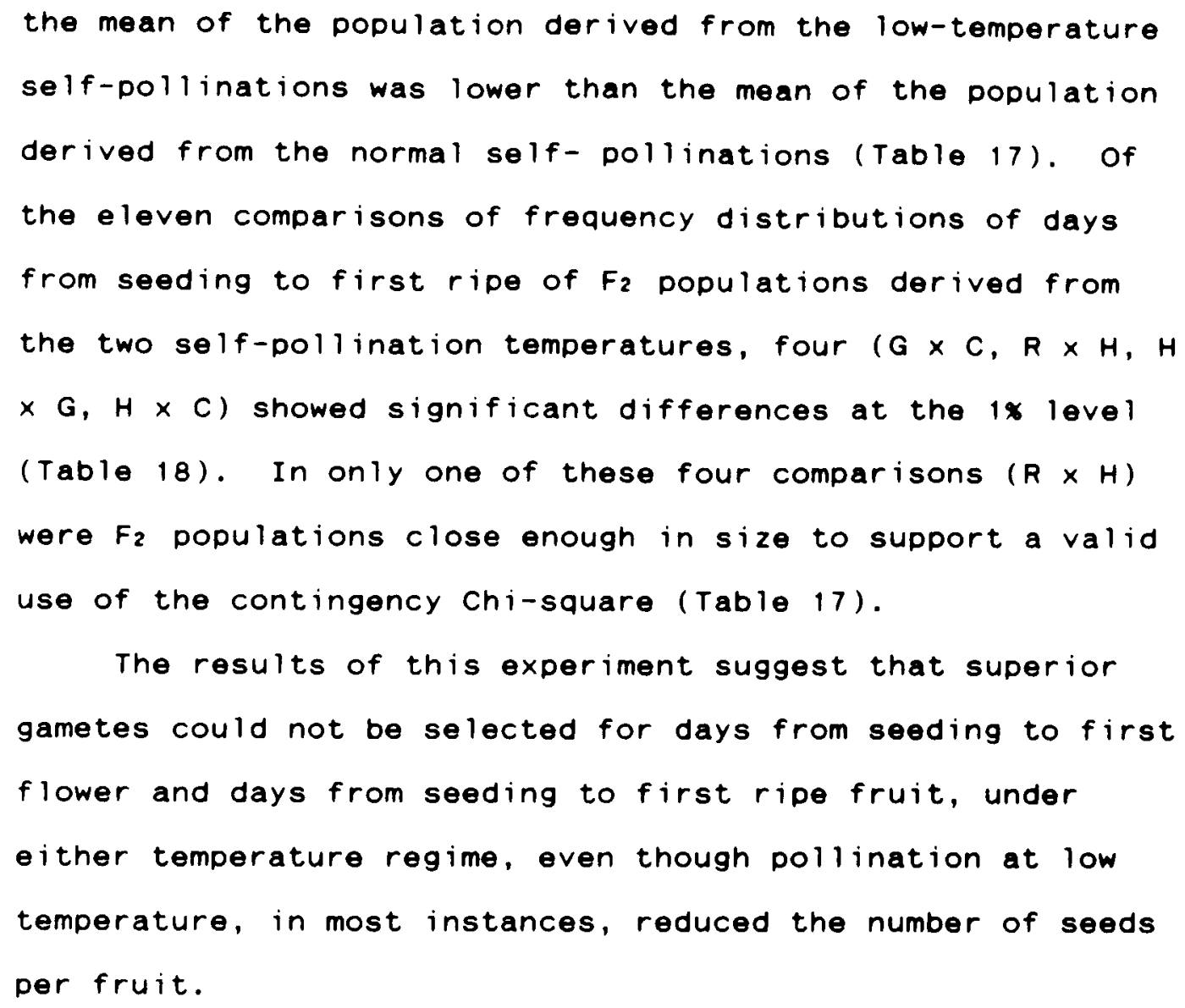


Table 19. Percent fruit set and mean seeds per fruit after self-pollination at normal ( $25 \mathrm{C}$ day / $20 \mathrm{C}$ night) or low ( 15 C day / 10 C night) temperature in Experiment 5.2 .

\begin{tabular}{|c|c|c|c|c|c|c|c|c|}
\hline \multicolumn{3}{|c|}{ Hybrid' } & $\begin{array}{c}\text { Temper- } \\
\text { ature } \\
\text { (C) }\end{array}$ & $\begin{array}{c}\text { No. } \\
\text { flowers } \\
\text { pollinated }\end{array}$ & $\begin{array}{l}\text { No. } \\
\text { fruit } \\
\text { set }\end{array}$ & $\begin{array}{c}\text { Percent } \\
\text { fruit } \\
\text { set }\end{array}$ & $\begin{array}{l}\text { No. } \\
\text { seeds }\end{array}$ & $\begin{array}{l}\text { Seeds } \\
\text { per } \\
\text { fruit }\end{array}$ \\
\hline G & $x$ & $\mathbf{R}$ & $\begin{array}{l}25 / 20 \\
15 / 10\end{array}$ & $\begin{array}{l}8 \\
5\end{array}$ & $\begin{array}{l}8 \\
2\end{array}$ & $\begin{array}{r}100.0 \\
40.0\end{array}$ & $\begin{array}{r}309 \\
15\end{array}$ & $\begin{array}{l}\text { NC } \\
\text { NC }\end{array}$ \\
\hline G & $x$ & C & $\begin{array}{l}25 / 20 \\
15 / 10\end{array}$ & $\begin{array}{l}14 \\
13\end{array}$ & $\begin{array}{l}7 \\
5\end{array}$ & $\begin{array}{l}50.0 \\
38.5\end{array}$ & $\begin{array}{l}65 \\
88\end{array}$ & $\begin{array}{l}\text { NC } \\
\text { NC }\end{array}$ \\
\hline G & $\begin{array}{l}x \\
.\end{array}$ & $H$ & $\begin{array}{l}25 / 20 \\
15 / 10\end{array}$ & $\begin{array}{r}9 \\
13\end{array}$ & $\begin{array}{l}7 \\
4\end{array}$ & $\begin{array}{l}77.8 \\
30.8\end{array}$ & $\begin{array}{r}387 \\
51\end{array}$ & $\begin{array}{l}\text { NC } \\
N C\end{array}$ \\
\hline$R$ & $\stackrel{x}{*}$ & $\mathbf{G}$ & $\begin{array}{l}25 / 20 \\
15 / 10\end{array}$ & $\begin{array}{r}6 \\
12\end{array}$ & $\begin{array}{l}2 \\
4\end{array}$ & $\begin{array}{l}33.3 \\
33.3\end{array}$ & $\begin{array}{r}12 \\
243\end{array}$ & $\begin{array}{l}N C \\
N C\end{array}$ \\
\hline $\mathbf{R}$ & $\begin{array}{l}x \\
י\end{array}$ & c & $\begin{array}{l}25 / 20 \\
15 / 10\end{array}$ & $\begin{array}{l}14 \\
13\end{array}$ & $\begin{array}{r}12 \\
9\end{array}$ & $\begin{array}{l}85.7 \\
69.2\end{array}$ & $\begin{array}{r}1,467 \\
229\end{array}$ & $\begin{array}{r}122.3 \\
25.4\end{array}$ \\
\hline $\mathbf{R}$ & $\begin{array}{l}x \\
" \prime\end{array}$ & $H$ & $\begin{array}{l}25 / 20 \\
15 / 10\end{array}$ & $\begin{array}{r}6 \\
11\end{array}$ & $\begin{array}{l}6 \\
6\end{array}$ & $\begin{array}{r}100.0 \\
54.5\end{array}$ & $\begin{array}{l}638 \\
135\end{array}$ & $\begin{array}{r}106.3 \\
22.5\end{array}$ \\
\hline C & $\begin{array}{l}x \\
"\end{array}$ & $\mathbf{G}$ & $\begin{array}{l}25 / 20 \\
15 / 10\end{array}$ & $\begin{array}{r}8 \\
13\end{array}$ & $\begin{array}{l}3 \\
3\end{array}$ & $\begin{array}{l}37.5 \\
23.1\end{array}$ & $\begin{array}{l}17 \\
25\end{array}$ & $\begin{array}{l}N C \\
N C\end{array}$ \\
\hline C & $\begin{array}{l}x \\
.\end{array}$ & $\mathbf{R}$ & $\begin{array}{l}25 / 20 \\
15 / 10\end{array}$ & $\begin{array}{l}12 \\
15\end{array}$ & $\begin{array}{l}12 \\
11\end{array}$ & $\begin{array}{r}100.0 \\
73.3\end{array}$ & $\begin{array}{r}1,085 \\
258\end{array}$ & $\begin{array}{l}90.4 \\
23.5\end{array}$ \\
\hline C & $\begin{array}{l}x \\
י\end{array}$ & $\mathbf{H}$ & $\begin{array}{l}25 / 20 \\
15 / 10\end{array}$ & $\begin{array}{r}6 \\
10\end{array}$ & $\begin{array}{l}3 \\
0\end{array}$ & $\begin{array}{r}50.0 \\
0.0\end{array}$ & $\begin{array}{r}31 \\
0\end{array}$ & $\begin{array}{r}10.3 \\
0.0\end{array}$ \\
\hline H & $\stackrel{x}{x}$ & $\mathbf{G}$ & $\begin{array}{l}25 / 20 \\
15 / 10\end{array}$ & $\begin{array}{l}13 \\
13\end{array}$ & $\begin{array}{r}10 \\
8\end{array}$ & $\begin{array}{l}76.9 \\
61.5\end{array}$ & $\begin{array}{l}681 \\
314\end{array}$ & $\begin{array}{l}68.1 \\
39.3\end{array}$ \\
\hline H & $\stackrel{x}{*}$ & $\mathbf{R}$ & $\begin{array}{l}25 / 20 \\
15 / 10\end{array}$ & $\begin{array}{l}12 \\
11\end{array}$ & $\begin{array}{l}8 \\
6\end{array}$ & $\begin{array}{l}66.7 \\
54.5\end{array}$ & $\begin{array}{r}437 \\
78\end{array}$ & $\begin{array}{l}54.6 \\
13.0\end{array}$ \\
\hline H & $\begin{array}{l}x \\
י\end{array}$ & c & $\begin{array}{l}25 / 20 \\
15 / 10\end{array}$ & $\begin{array}{r}10 \\
9\end{array}$ & $\begin{array}{l}9 \\
0\end{array}$ & $\begin{array}{r}90.0 \\
0.0\end{array}$ & $\begin{array}{r}631 \\
0\end{array}$ & $\begin{array}{r}70.1 \\
0.0\end{array}$ \\
\hline
\end{tabular}

1 Parental cultivars are designated as follows: Gemstate (G): Rocket (R): Crimsonvee (C); and Harvestvee (H).

2 Percent fruit set equals the number of fruit set divided by the number of flowers pollinated multiplied by 100 .

3 Not calculatable (NC) due to blossom end rot. 
pollination under normal temperature ( $T a b l e ~ 19)$ (Wilcoxon's signed Rank test, $P=5 x)$. These results agree with those obtained by Maisonneuve et al. (1986).

Eight $F_{2}$ populations derived from normal-temperature self-pollination treatments were compared with genetically similar populations derived from low-temperature pollination ( $\operatorname{Tables} 15,16,17,18$ ). The mean number of days from seeding to first flower differed by one or more days for only one $(R \times C)$ of eight comparisons (Table 15). For this comparison, the mean number of days for the population derived from low-temperature self-pollination was significantly less ( $t$-test, $P=5 x$ ) than that for the population derived from the normal temperature pollination (Table 15). When the frequency distributions of days from seeding to first flower of $F_{2}$ populations derived from normal temperature self-pollinations were compared to similar populations derived from low-temperature self-pollination, two of eight comparisons $(R \times C, C \times R)$ showed significant differences (Table 16). The mean number of days from seeding to first ripe fruit differed by one or more days for two $(R \times G, R \times C)$ of eight comparisons (Table 17). In one of these comparisons $(R \times C)$ the difference was significant $(t$-test, $P=5 x)$. In this comparison, the mean number of days of the population derived from low temperature selfpollination was less than that of the population derived from normal temperature self-pollination (Table 17). None 


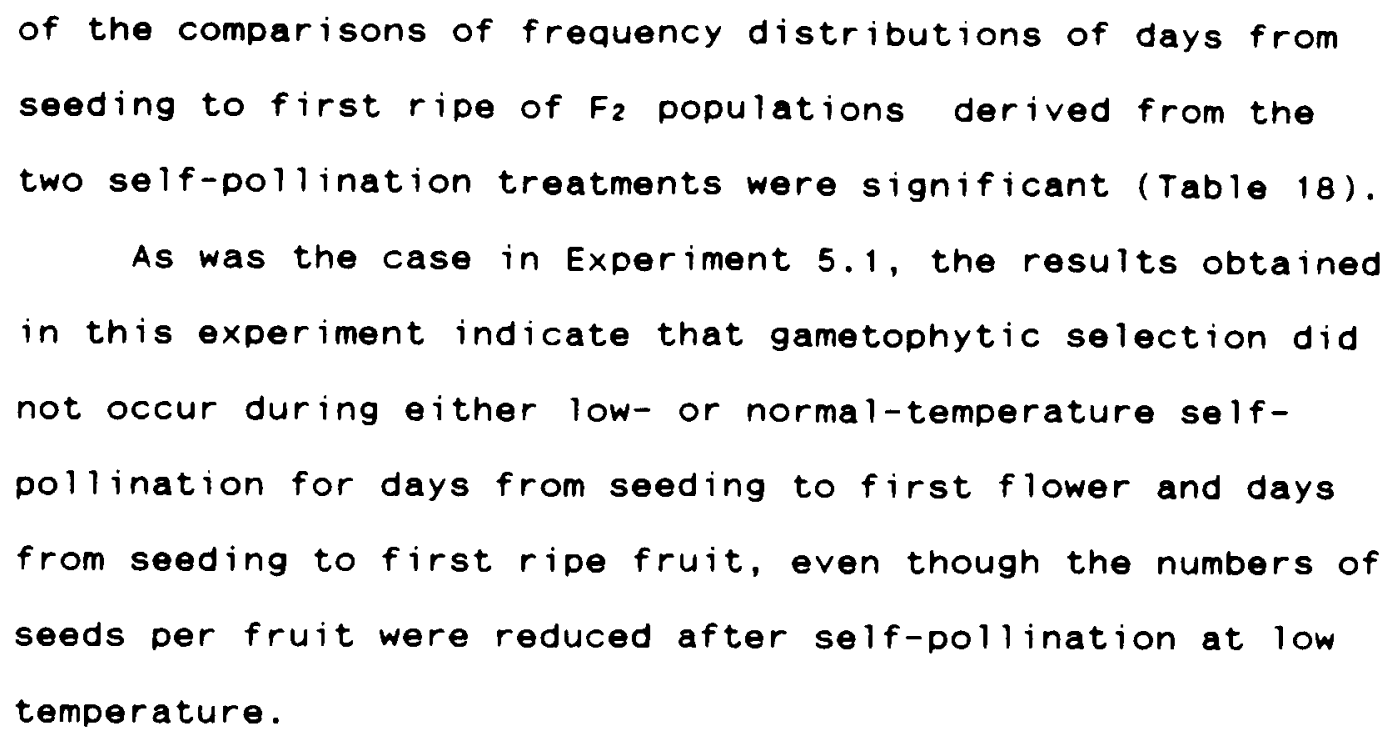


Table 20. Percent fruit set and mean seeds per fruit after self-pollination at normal (25 C day/20 C night) or low (15 C day / $10 \mathrm{C}$ night) temperature in Experiment 5.3.

\begin{tabular}{|c|c|c|c|c|c|c|c|c|}
\hline & br & rid' & $\begin{array}{l}\text { Temper- } \\
\text { ature } \\
\text { (C) }\end{array}$ & $\begin{array}{l}\text { No. } \\
\text { flowers } \\
\text { pollinated }\end{array}$ & $\begin{array}{l}\text { No. } \\
\text { fruit } \\
\text { set }\end{array}$ & $\begin{array}{l}\text { Percent } \\
\text { fruit } \\
\text { set }\end{array}$ & $\begin{array}{l}\text { No. } \\
\text { seeds }\end{array}$ & $\begin{array}{l}\text { Seeds } \\
\text { per } \\
\text { fruit }\end{array}$ \\
\hline $\mathbf{G}$ & $\begin{array}{l}x \\
.\end{array}$ & $\mathbf{R}$ & $\begin{array}{l}25 / 20 \\
15 / 10\end{array}$ & $\begin{array}{l}19 \\
23\end{array}$ & $\begin{array}{l}18 \\
22\end{array}$ & $\begin{array}{l}94.7 \\
95.7\end{array}$ & $\begin{array}{l}1,955 \\
1,087\end{array}$ & $\begin{array}{r}108.6 \\
49.4\end{array}$ \\
\hline G & $\begin{array}{l}x \\
.\end{array}$ & C & $\begin{array}{l}25 / 20 \\
15 / 10\end{array}$ & $\begin{array}{l}16 \\
18\end{array}$ & $\begin{array}{l}15 \\
15\end{array}$ & $\begin{array}{l}93.8 \\
83.3\end{array}$ & $\begin{array}{r}1,142 \\
564\end{array}$ & $\begin{array}{l}76.1 \\
37.6\end{array}$ \\
\hline $\mathbf{G}$ & $\begin{array}{l}x \\
.\end{array}$ & $H$ & $\begin{array}{l}25 / 20 \\
15 / 10\end{array}$ & $\begin{array}{l}14 \\
20\end{array}$ & $\begin{array}{l}14 \\
13\end{array}$ & $\begin{array}{r}100.0 \\
65.0\end{array}$ & $\begin{array}{r}1,120 \\
156\end{array}$ & $\begin{array}{l}80.0 \\
12.0\end{array}$ \\
\hline $\mathbf{R}$ & $\begin{array}{l}x \\
.\end{array}$ & $\mathbf{G}$ & $\begin{array}{l}25 / 20 \\
15 / 10\end{array}$ & $\begin{array}{l}24 \\
23\end{array}$ & $\begin{array}{l}22 \\
14\end{array}$ & $\begin{array}{l}91.7 \\
60.9\end{array}$ & $\begin{array}{r}1,841 \\
190\end{array}$ & $\begin{array}{l}83.7 \\
13.6\end{array}$ \\
\hline$R$ & $x$ & C & $\begin{array}{l}25 / 20 \\
15 / 10\end{array}$ & $\begin{array}{l}11 \\
12\end{array}$ & $\begin{array}{r}9 \\
10\end{array}$ & $\begin{array}{l}81.8 \\
83.3\end{array}$ & $\begin{array}{l}510 \\
333\end{array}$ & $\begin{array}{l}56.6 \\
33.3\end{array}$ \\
\hline $\mathbf{R}$ & $\begin{array}{l}x \\
y\end{array}$ & $H$ & $\begin{array}{l}25 / 20 \\
15 / 10\end{array}$ & $\begin{array}{l}15 \\
19\end{array}$ & $\begin{array}{l}7 \\
8\end{array}$ & $\begin{array}{l}46.7 \\
42.1\end{array}$ & $\begin{array}{l}483 \\
170\end{array}$ & $\begin{array}{l}69.0 \\
21.3\end{array}$ \\
\hline C & 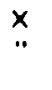 & $\mathbf{G}$ & $\begin{array}{l}25 / 20 \\
15 / 10\end{array}$ & $\begin{array}{l}20 \\
27\end{array}$ & $\begin{array}{l}18 \\
13\end{array}$ & $\begin{array}{l}90.0 \\
48.1\end{array}$ & $\begin{array}{r}1,316 \\
407\end{array}$ & $\begin{array}{l}73.1 \\
31.3\end{array}$ \\
\hline C & $\begin{array}{l}x \\
\ddot{n}\end{array}$ & $\mathbf{R}$ & $\begin{array}{l}25 / 20 \\
15 / 10\end{array}$ & $\begin{array}{l}13 \\
15\end{array}$ & $\begin{array}{r}12 \\
7\end{array}$ & $\begin{array}{l}92.3 \\
46.7\end{array}$ & $\begin{array}{r}1,313 \\
119\end{array}$ & $\begin{array}{r}109.4 \\
17.0\end{array}$ \\
\hline C & $\begin{array}{l}x \\
.\end{array}$ & $H$ & $\begin{array}{l}25 / 20 \\
15 / 10\end{array}$ & $\begin{array}{l}9 \\
8\end{array}$ & $\begin{array}{l}2 \\
0\end{array}$ & $\begin{array}{r}22.2 \\
0.0\end{array}$ & $\begin{array}{r}109 \\
0\end{array}$ & $\begin{array}{r}54.5 \\
0.0\end{array}$ \\
\hline$H$ & $\begin{array}{l}x \\
\|\end{array}$ & $\mathbf{R}$ & $\begin{array}{l}25 / 20 \\
15 / 10\end{array}$ & $\begin{array}{l}13 \\
16\end{array}$ & $\begin{array}{r}10 \\
4\end{array}$ & $\begin{array}{l}76.9 \\
25.0\end{array}$ & $\begin{array}{r}818 \\
49\end{array}$ & $\begin{array}{l}81.8 \\
12.3\end{array}$ \\
\hline$H$ & $x$ & C & $\begin{array}{l}25 / 20 \\
15 / 10\end{array}$ & $\begin{array}{l}11 \\
13\end{array}$ & $\begin{array}{l}7 \\
1\end{array}$ & $\begin{array}{r}63.6 \\
7.7\end{array}$ & $\begin{array}{r}221 \\
17\end{array}$ & $\begin{array}{l}31.6 \\
17.0\end{array}$ \\
\hline
\end{tabular}

- Parental cultivars are designated as follows: Gemstate (G): Rocket (R); Crimsonvee (C); and Harvestvee (H).

2 Percent fruit set equals the number of fruit set divided by the number of flowers pollinated multiplied by 100 . 
the affect of pollination temperature of percent fruit set and number of seeds per fruit, are probably due to inherent limitations of Wilcoxon's Signed Rank Test. As the number of comparisons increases above ten, the efficiency of the test increases (Snedecor and Cochran, 1967). The number of comparisons for each experiment, for percent fruit set or number of seeds per fruit, were eleven and in one instance only seven. When data from the three experiments were combined, low temperature self-pollination significantly reduced both percentage fruit set (number of comparisons = 33) and the number of seeds per fruit (number of comparisons =29) (Wilcoxon's Signed Rank Test, $P=5 x$ ).

Days from seeding to first flower and days from seeding to first ripe fruit of $F_{2}$ populations derived from normaltemperature, self-pollination treatments were compared with similar genetic populations derived from the low-temperature treatment (Tables $15,16,17,18$ ). The mean numbers of days from seeding to first flower differed by one or more days for six comparisons $(G \times R, G \times H, R \times G, R \times H, C \times G, H \times$ C) (Table 15). In four of these six comparisons ( $G \times H, R \times$ $G, R \times H, C \times G$ ) the differences were significant (t-test, $P$ $=5 \times)$. In two comparisons $(G \times H, R \times G)$ the means of the populations derived from low-temperature pollination were less than those of populations derived from normaltemperature self-pollinations (Table 15). When the frequency distributions of days from seeding to first flower 
of $F_{2}$ populations derived from normal-and low-temperature self-pollinations were compared, four of ten comparisons (R $\times G, R \times H, C \times G, H \times C)$ showed significant differences (Table 16). In one comparison $(H \times C)$, significance may have been caused by a large difference in the size of the populations compared (Table 15) (Steel and Torrie, 1980). The mean number of days from seeding to first ripe differed by one or more days for two $(H \times R, H \times C)$ of ten comparisons (Table 17). For both comparisons, this difference was not significant $(t-t e s t, p=5 x)$. Only one of ten comparisons $(H \times C)$ of frequency distributions of days from seeding to first $r$ ipe of $F_{2}$ populations derived from the two self-pollination treatments was significant (Table 18). Significance of this comparison was most likely due to the difference in size of the populations compared. The results of this experiment agree with those of Experiment 5.1 and 5.2 in that they suggest that gametophytic selection was not successful for either days from seeding to first flower or days from seeding to first ripe fruit, under low or normal pollination temperature. The results, furthermore, were not changed by the timing of the style cut after pollination or by the location of the style cut (Table 9). Although the results of these experiments seem to cast doubt on using low temperature to select early maturity components, other workers have used temperature stress during pollen development and pollen 
storage successfully in gametophytic selection schemes (Mulinix and Iezzoni, 1988; Rodriquez-Garay and Barrow, 1988). Several aspects of these experiments could be modified to increase the likelihood of significant shifts in the mean of progeny generations, as for example, decreasing the time after pollination before style cutting from 72 to 48 hours to increase selection pressure; increasing the size of the $F_{2}$ populations planted in the field to improve sampling of progeny derived from the self-pollination treatments; and, fine-tuning the stress temperatures to enhance selection pressure.

choice of parents also plays an important role. Parents should have large enough differences to achieve significant and useful population shifts (Maisonneuve et a 1., 1986). In this study, the differences between early and late cultivars for number of days from seeding to first flower and number of days from seeding to first ripe were 3 to 8 days (Table 15) and 14 to 23 days (Table 17), respectively. To date, the only successful gametophytic selection schemes that have been developed for tomato utilize interspecific variation (Sacher et al., 1983; Zamir et al., 1981; Zamir et al., 1982; Zamir and Vallejos, 1983; Zamir and Gadish, 1987).

Planting early in the season to increase exposure to suboptimal temperatures might have improved the separation of genetic differences in capacity to set fruit at low 
ambient temperatures. The maximum and minimum daily temperatures in Durham, NH, during the duration of field Experiments 5.1 (1989), 5.2 and 5.3 (1990) are presented in Appendix 2 .

The cornerstone of any gametophytic selection scheme is that the genes of the desired sporophytic character also must be expressed in the gametophytic phase (Tanksley et a l., 1981) and that an appropriate selection pressure must be employed (Zamir, 1983). In this study, the gametophytic selection system was utilized to to try to select for characters that were not exclusively controlled by the sporophyte (figure 1). A possible reason for the lack of response to gametophytic selection in Experiment 5 and the other in vivo experiments ( 3 and 4 ) is that the genes controlling days from seeding to first flower and days from seeding to first ripe fruit are not expressed in the pollen phase. Unlike the results of Maisonneuve et al. (1986), the temperature by cultivar interactions for in vitro pollen germination and tube growth observed in Experiment 1 suggested that temperature could be used to favor and select pollen with early maturity genes. But, as has been the case in muskmelon (cucumis melo L.), effects of temperature on in vitro pollen germination and pollen tube behavior cannot always be used to predict pollen germination or pollen tube behavior in vivo (Maestro and Alvarez, 1988). 


\section{CONCLUSIONS}

It is theorized that gametophytic selection can increase selection efficiency by decreasing the number of $F_{2}$ plants required to evaluate a quantitatively inherited trait, compared to the number of $F_{2}$ plants required in a sporophytic selection scheme. Furthermore, successful application of selection pressure at the gametophytic stage should shift the $F_{2}$ population mean toward the desired extreme for the trait selected. Because early maturity frequently implies flowering and pollination early in the season when temperatures are low, it seemed plausible that temperature might be used as an effective agent for applying selection pressure at the gametophytic stage. In theory, the most vigorous gametes would compete successfully within the stress imposed by low temperature. This competitive advantage might be realized as greater pollen grain germination or as more rapid pollen tube growth of "early" gametes as compared with "late" gametes.

In this study, differences for in vitro pollen germination and pollen tube growth under low and normal temperatures were related to the maturity class of the cultivar. Optimal temperatures for in vitro germination and tube growth appeared to be greater than $15 \mathrm{c}$ for early cultivars and approximately $15 \mathrm{C}$ for late cultivars. In vivo pollen germination percentage and rate of tube growth 


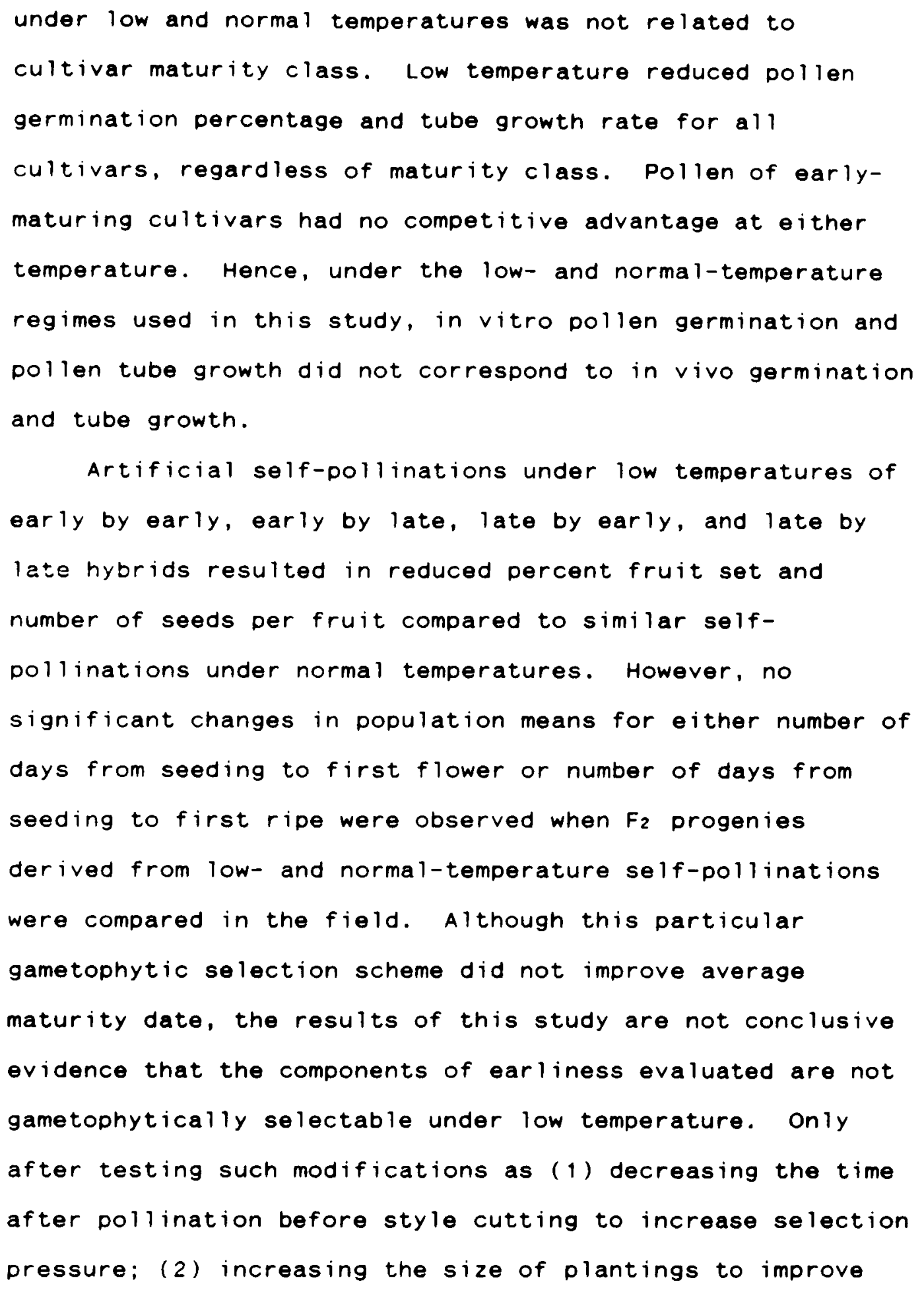




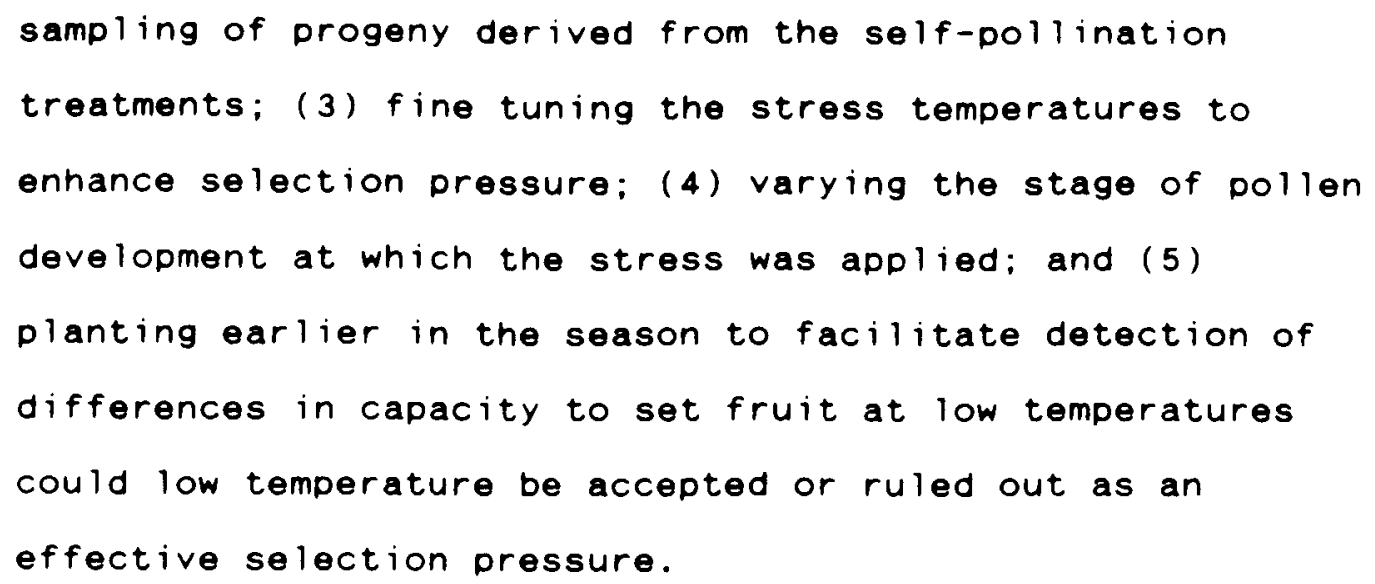


Pedigrees of six tomato cultivars selected for study.

A. Rocket (Allen and Walkof, 1967).

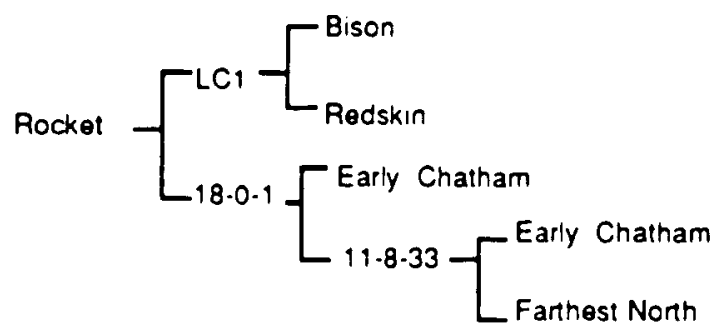

B. Gemstate (Boe. Pelofske, and Bakken, 1980).

Gemstate $\underbrace{\text { Sub-Artic Midi }}_{\text {Pixies Hybrid (closed pedigree) }}$

C. Bellstar (Metcalf, 1983).

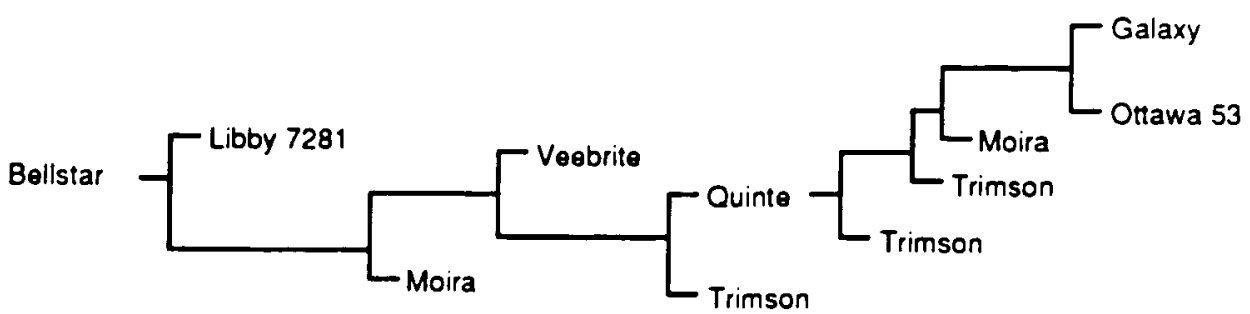

89 
D. Earlirouge (Metcalf, 1977).

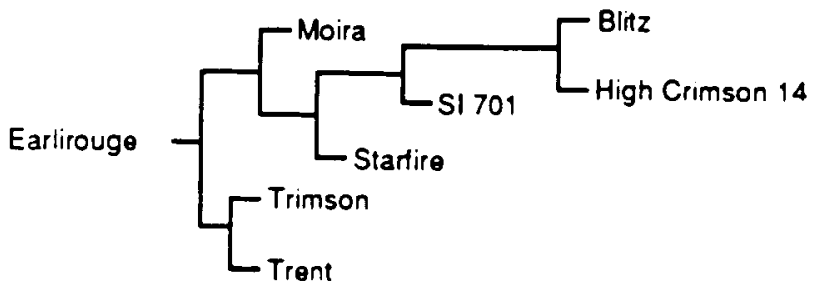

E. Crimsonver (Kerr, 1981).

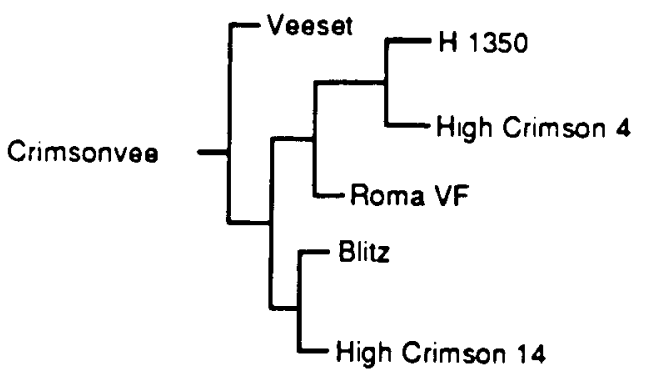


F. Harvestver (Kerr, 1981).

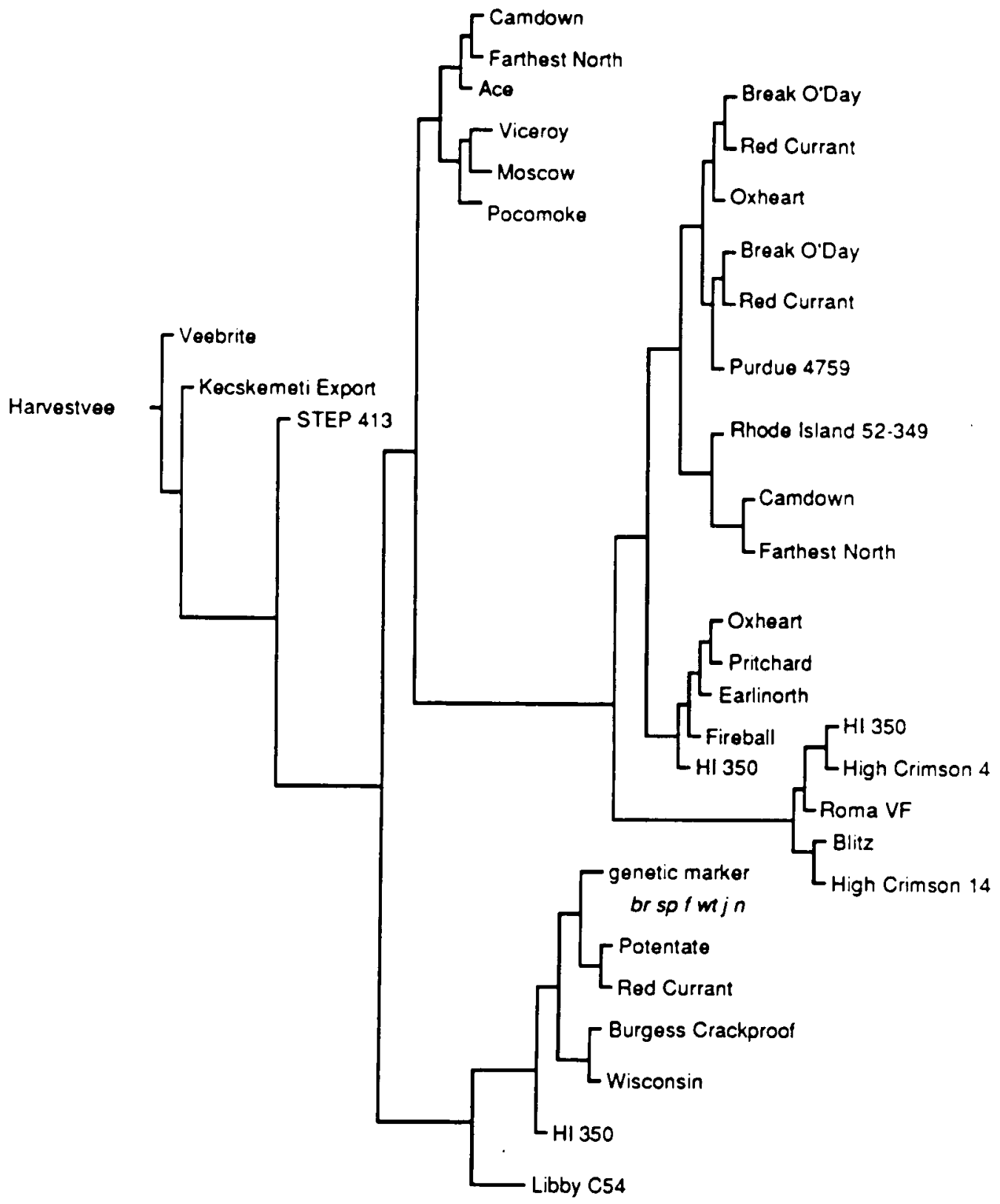

91 
Maximum and minimum daily temperatures recorded in Durham, $\mathrm{NH}$, from May to September, 1989 and from May to September, 1990. Measurements were made six feet above the ground, at a weather station 0.3 miles away from Woodman Farm.
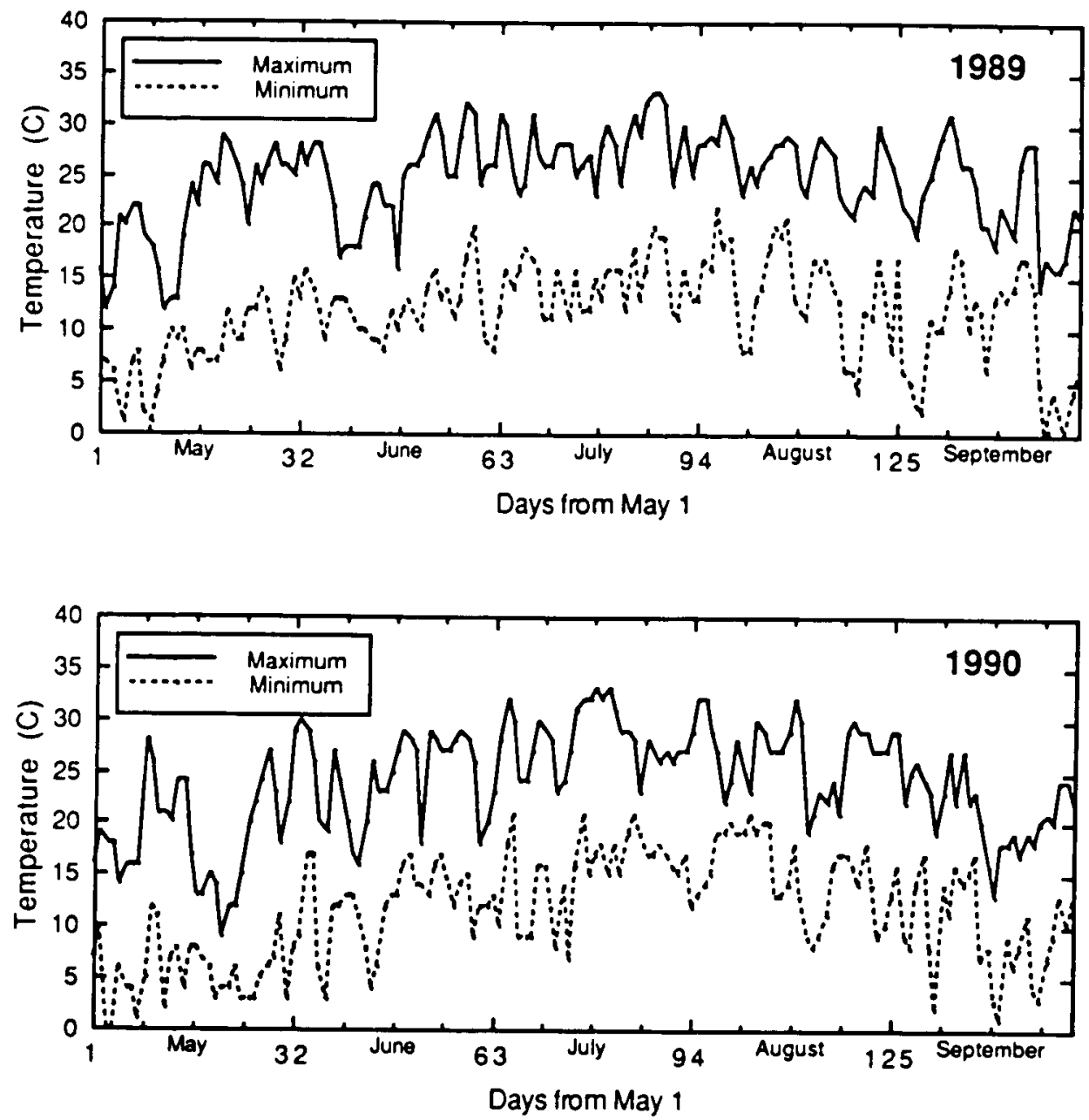


\title{
LITERATURE CITED
}

\begin{abstract}
Allen, H.T., and C. Walkof. 1967. 'Rocket' tomato. Can. J. Plant Sci. 47: 117-118.

Bernier, C.C., and A.C. Ferguson. 1962. A study of the association between earliness, fruit size and early yield in determinate tomatoes. Can. J.Plant Sci. 42 : $635-641$.
\end{abstract}
Boe, A.A., P.J. Pelofske, and T.J. Bakken. 1980. 'Santa', 'Gemstate', and 'Benewah' tomatoes. Hortsci. 15: 536-537.

Bohn, G.N. 1955. A genetic difference in pollen tube growth in the tomato. Rpt. Tom. Genet. Coop. 5: 6 .

Charles, W.B., and R.E. Harris. 1972. Tomato fruit-set at high and low temperatures. Can. J.Plant Sci. 52: 497-506.

Chatterton, N.J., and A.R. Kadish. 1969. A temperature gradient germinator. Agronomy J. 61: 643-644.

Cuartero, J., and J.I. Cubero. 1982. Genotype-environment interaction in tomato. Theor. App 1. Genet. 61: 273277.

Daubeny, H.A. 1961. Earliness in tomato varieties with special reference to ability to set fruit at low temperatures. Proc. Amer. Soc. Hort. Sci. 78: 445449 .

Dempsey, W.H. 1970. Effects of temperature on pollen germination and tube growth. Rpt. Tom. Genet. Coop. 20: $15-16$.

Dempsey, W.H., and J.E. Boynton. 1962. Effect of time of day on controlled pollinations. Rpt. Tom. Genet. coop. $12: 23-24$.

Fogle, H.W., and T.M. Currence. 1950. Inheritance of fruit weight and earliness in a tomato cross. Genetics 35: 363-380.

Frazier, W.A. 1951. A variety with the unusual ability to set fruit at low temperatures. Rpt. Tom. Genet. COOP. 1: 6 . 


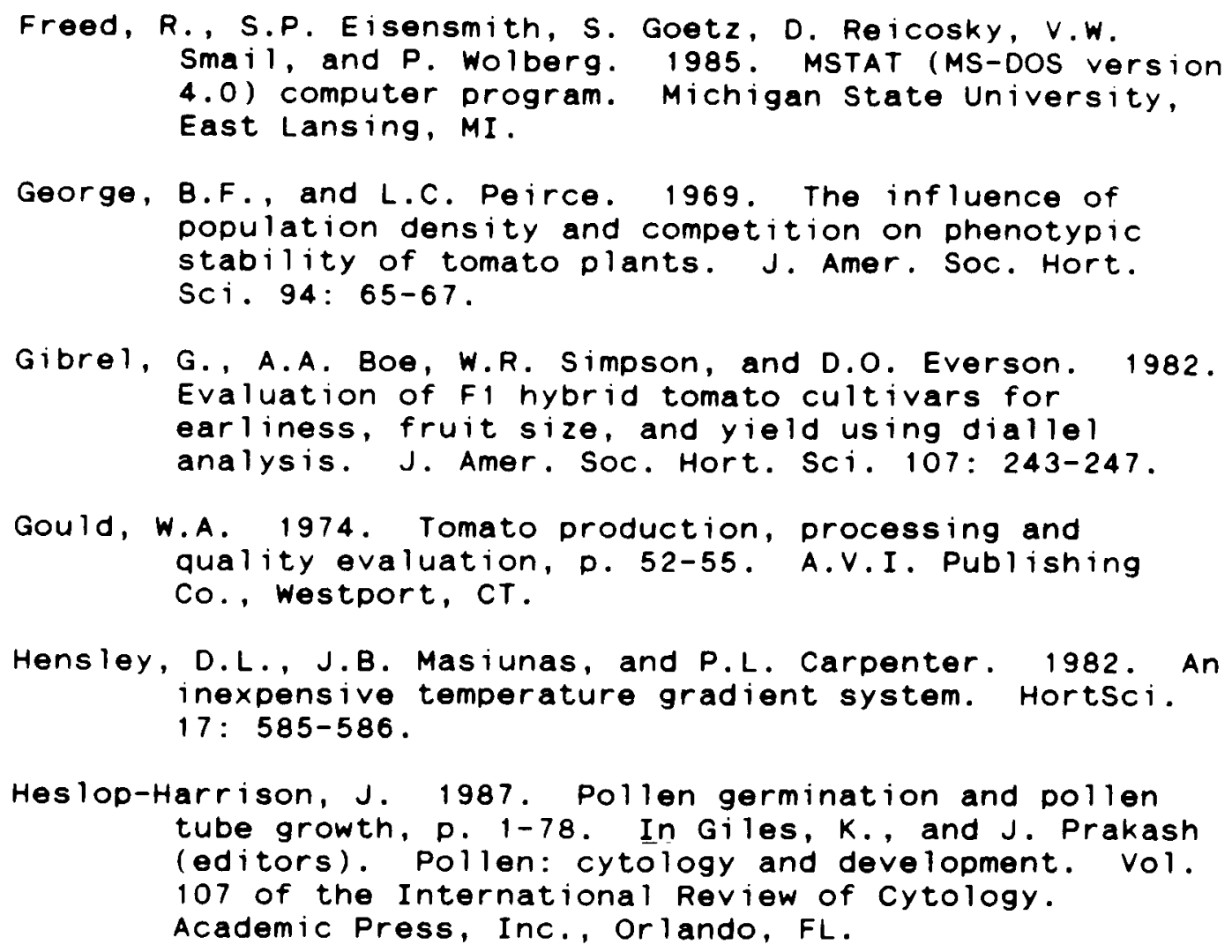

Gibrel, G., A.A. Boe, W.R. Simpson, and D.O. Everson. 1982. Evaluation of $F 1$ hybrid tomato cultivars for earliness, fruit size, and yield using diallel analysis. J. Amer. Soc. Hort. Sci. 107: 243-247.

Gould, W.A. 1974. Tomato production, processing and quality evaluation, D. 52-55. A.V.I. Publishing Co., Westport, CT.

Honma, S., S.H. Wittwer, and S.C. Phatak. 1963. Flowering and earliness in the tomato - inheritance of associated characteristics. J. Heredity 54: 212218.

Hornby, C.A., and H.A. Daubeny. 1956. Genetic differences in pollen production, germination and growth. Rpt. Tom. Genet. Coop. 6: 16 .

Hutton, M.G. 1988. Genetics and physiology of cold tolerance in muskmelon (Cucumis melo L.). PhD Dissertation, University of New Hampshire, Durham, $\mathrm{NH}$.

Kemp, G.A. 1965. Inheritance of fruit set at low temperatures in the tomato. Proc. Amer. Soc. Hort. Sci. 86: 565-568.

Kemp, G.A. 1966. Fruit set at low temperatures. Rep. Tom. Genet. Coop. 16: 13.

Kemp, G.A. 1968. Low temperature growth responses of the tomato. Can. J. Plant Sci. 48: 281-286. 
Kerr, E.A. 1955. Some factors affecting earliness in the tomato. Can. J.Agric. Sci. 35:300-308.

Kerr, E.A. 1981. 'Crimsonvee' and 'Harvestvee' tomato. Rpt. Tom. Genet. Coop. 31: 45-46.

Knox, R.B., E.G. Williams, and C. Dumas. 1986. Pollen, pistil and reproductive function in crop plants, $p$. 9-79. In Janick, J. (editor). Vol. 4 of Plant Breeding Reviews. AVI Publishing Co., Inc. Westport, CT.

Learner, E.N., and S.H. Wittwer. 1953. Some effects of photoperiodicity and thermoperiodicity on vegetative growth, flowering and fruiting of the tomato. Proc. Amer. Soc. Hort. Sci. 61: 373-380.

Luza, J.G., V.S. Polito, and S.A. Weinbaum. 1987. Staminate bloom date and temperature responses of pollen germination and tube growth in two walnut (Juglans) species. Amer. J. Bot. 74: 1898-1903.

Maestro, M.C., and J.Alvarez. 1988. The effects of temperature on pollination and pollen tube growth in muskmelon (Cucumis melo L.). Scientia Hort. 36 : 173-181.

Maisonneuve, B., and A.P.M. den Nijs. 1984. In vitro pollen germination and tube growth of tomato (Lycopersicon esculentum $M i 11$. ) and its relation with plant growth. Euphytica 33: 833-840.

Maisonneuve, B., N.G. Hogenboom, and A.P.M. den Nijs. 1986.

Pollen selection in breeding tomato (Lycopersicon esculentum Mill.) for adaptation to low temperature. Euphytica 35: 983-992.

Martin, F.W. 1959. Staining and observing pollen tubes in the style by means of fluorescence. Stain Tech. 34: $125-128$.

Metcalf, J.G. 1977. 'Earlirouge' tomato. Rp . Tom. Genet. Coop. $27: 64$.

Metcalf, J.G. 1983. 'Bellstar' tomato. Rpt. Tom. Genet. CoOp. 33: 52 .

Mulinix, C.A., and A.F. Iezzoni. 1988. Microgametophytic selection in two alfalfa (Medicago sativa L.)

clones. Theor. Appl. Genet. 75: 917-922. 


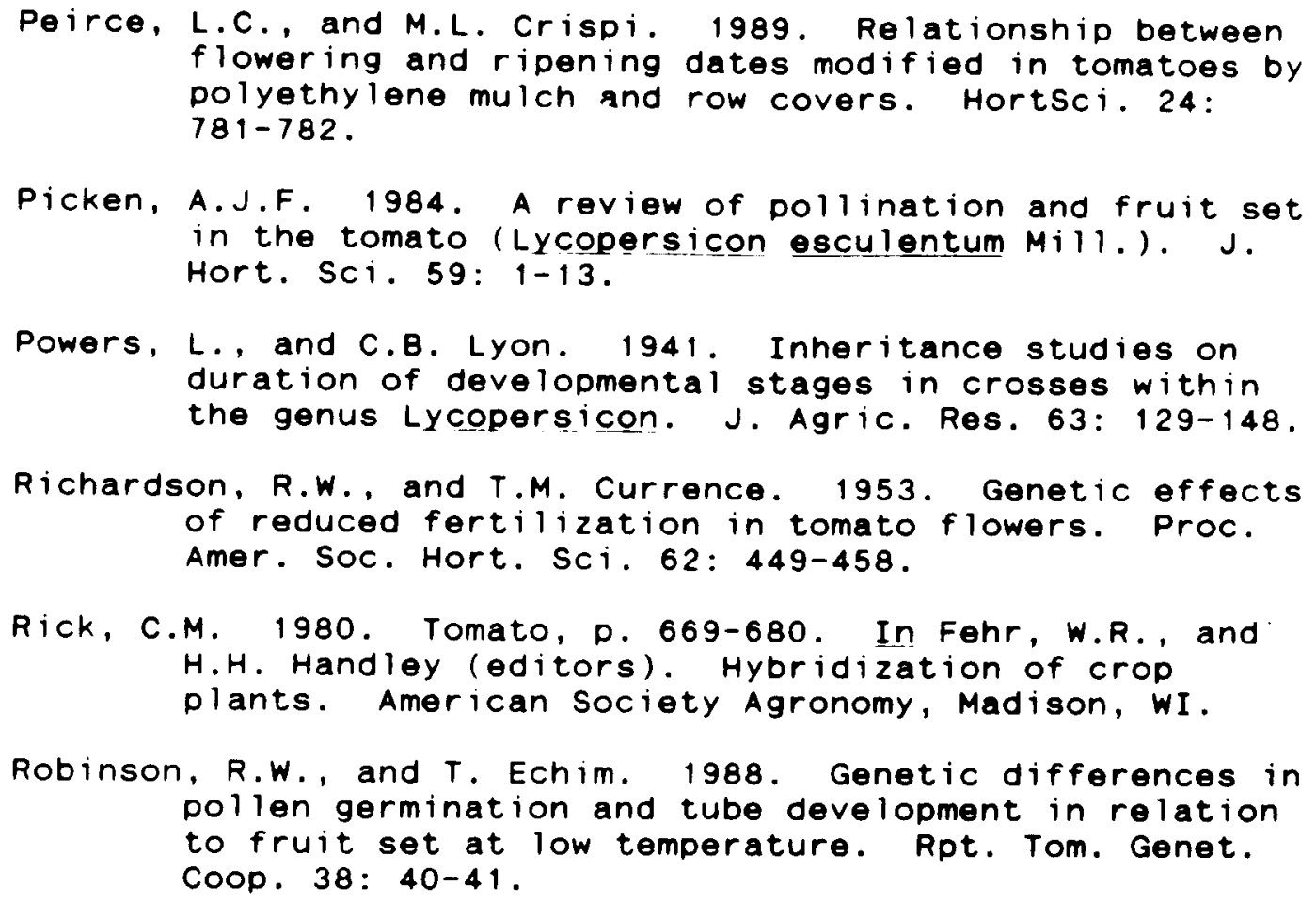

Robinson, R.W., and T. Echim. 1988. Genetic differences in pollen germination and tube development in relation to fruit set at low temperature. Rpt. Tom. Genet. coop. 38: 40-41.

Rodriguez-Garay, B., and J.R. Barrow. 1988. Pollen selection for heat tolerance in cotton. Cropsci. 28: $857-858$.

Sacher, R.F., D.L. Mulcahy, and R.C. Staples. 1983. Developmental selection during self-pollination of Lycopersicon $x$ Solanum $F 1$ for salt tolerance of $F 2$, D. 329-334. In Mulcahy, D.L., and E. Ottaviano (editors). Pollen: biology and implications for plant breeding. Elsevier Science Publishing Co., Inc., New York, NY.

Snedecor, G.W., and W.G. Cochran. 1967. Statistical methods. Sixth edition. Iowa State University Press, Ames, IA.

Steel, R.G., and J.H. Torrie. 1980. Principles and procedures of statistics. Second edition. McGrawHill Book Co., New York, NY.

Stephenson, A.G., and R.I. Bertin. 1983. Male competition, female choice and sexual selection in plants, $p$. 110-149. In Real, L. (editor). Pollination Biology. Academic Press Inc. New York, NY. 
Stevens, M.A., and C.M. Rick. 1986. Genetics and breeding, p. 77. In Atherton, J.G., and J. Rudich (editors). The tomato crop - a scientific basis for improvement. Chapman and Hall, New York. NY.

Strickberger, M.W. 1976. Genetics. Second edition. MacMillan Publishing Co., New York, NY.

Tanksley, S.D., D. Zamir, and C.M. Rick. 1981. Evidence for extensive overlap of sporophytic and gametophytic gene expression in Lycopersicon esculentum. Science 213: 453-455.

Vasil, I.K. 1987. Physiology and culture of pollen, $p$. 127-174. In Giles, K., and J. Prakash (editors). Pollen: cytology and development. Vol. 107 of the International Review of Cytology. Academic Press, Inc., Or lando, FL.

Watada, A.E., K.H. Norris, J.T. Worthington, and D.R. Massie. 1976. Estimation of chlorophyll and carotenoid contents of whole tomato by light absorbance technique. J. Food Sci. 41: 329-332.

Went, F.W. 1944. Plant growth under controlled conditions. II. Thermoperiodicity in growth and fruiting of the tomato. Amer. J. Bot. 31: 135-150.

Went, F.W. 1945. Plant growth under controlled conditions. $\checkmark$. The relation between age, light, variety and thermoperiodicity of tomatoes. Amer. J. Bot. 32 : 469-479.

Wittwer, S.H., H. Stallworth, and M.J. Howell. 1948. The value of a "hormone" spray for overcoming delayed fruit set and increasing yields of outdoor tomatoes. Proc. Amer. Soc. Hort. Sci. 51: 371-380.

Zamir, D. 1983. Pollen gene expression and selection: applications in plant breeding, p. 313-330. In Tanksley, S.D., and T.J. Orton (editors). Isozymes in plant genetics and breeding, part A. Elsevier Science Publishers B.V., Amsterdam.

Zamir, D., and I. Gadish. 1987. Pollen selection for low temperature adaptation in tomato. Theor. Appl. Genet. 74: 545-548.

Zamir, D., and E.C. Vallejos. 1983. Temperature effects on haploid selection of tomato microspores and pollen grains, D. 335-342. In Mulcahy, D.L., and E. ottaviano (editors). Pollen: biology and impli- 


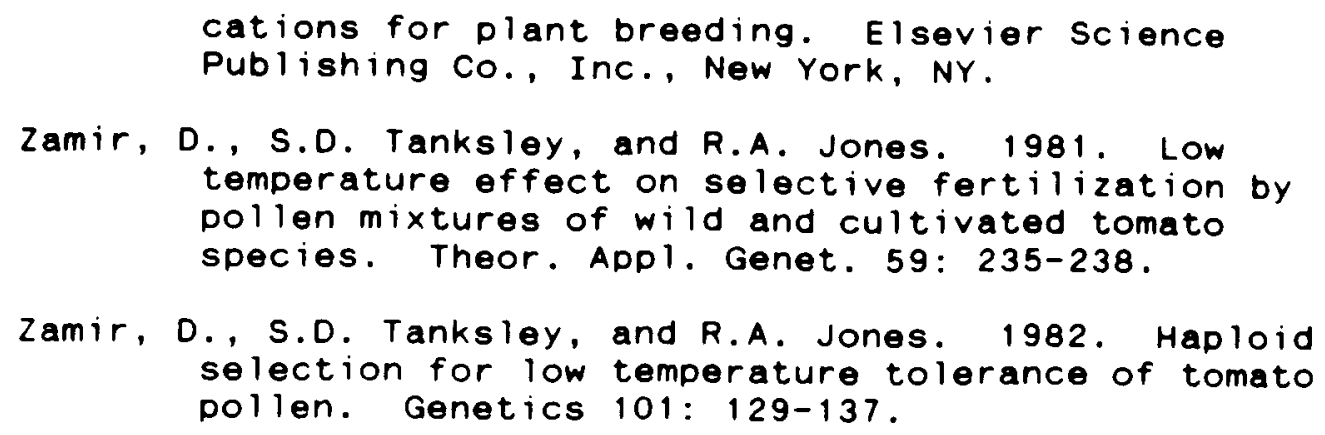

